\title{
STATE TAXATION AND THE REALLOCATION OF BUSINESS ACTIVITY: EVIDENCE FROM ESTABLISHMENT-LEVEL DATA
}

\author{
Xavier Giroud \\ Joshua Rauh \\ Working Paper 21534 \\ http://www.nber.org/papers/w21534
NATIONAL BUREAU OF ECONOMIC RESEARCH
1050 Massachusetts Avenue
Cambridge, MA 02138
September 2015

We thank David Colino, Bryan Chang, and Young Soo Jang for research assistance. We are grateful to Jeffrey Brown, Austan Goolsbee, Holger Mueller, Amit Seru, and seminar participants at Stanford GSB for helpful discussions. Any opinions and conclusions expressed herein are those of the authors and do not necessarily represent the views of the U.S. Census Bureau. All results have been reviewed to ensure that no confidential information is disclosed. The views expressed herein are those of the authors and do not necessarily reflect the views of the National Bureau of Economic Research.

At least one co-author has disclosed a financial relationship of potential relevance for this research. Further information is available online at http://www.nber.org/papers/w21534.ack

NBER working papers are circulated for discussion and comment purposes. They have not been peerreviewed or been subject to the review by the NBER Board of Directors that accompanies official NBER publications.

(C) 2015 by Xavier Giroud and Joshua Rauh. All rights reserved. Short sections of text, not to exceed two paragraphs, may be quoted without explicit permission provided that full credit, including $\odot$ notice, is given to the source. 
State Taxation and the Reallocation of Business Activity: Evidence from Establishment-Level

Data

Xavier Giroud and Joshua Rauh

NBER Working Paper No. 21534

September 2015

JEL No. H25,H71,H73

\begin{abstract}
In a sample of over 27 million establishments of U.S. firms with activities in more than one state, we estimate the impact of state business taxation on business activity. Only firms organized as subchapter $\mathrm{C}$ corporations are subject to the corporate tax code, whereas the income of partnerships, sole-proprietorships, and $\mathrm{S}$ corporations is passed through annually to the firm's owners and taxed at individual rates. For $\mathrm{C}$ corporations, both employment at existing establishments (intensive margin) and the number of establishments in the state (extensive margin) have corporate tax elasticities of -0.4. Pass-through entities, which serve as a control group for the corporate tax reforms, respond only to the personal tax code, with tax elasticities of -0.2 to -0.3 . Around half of the effects are driven by reallocation of productive resources to other states where the treated firms have establishments. Capital shows similar patterns but is $36 \%$ less elastic than labor. A narrative approach confirms that the results are robust and strongest in the sample of tax changes that were implemented due to inherited budget deficits, long-run goals, or cross-state variation caused by Federal tax reforms.
\end{abstract}

\author{
Xavier Giroud \\ MIT Sloan School of Management \\ 100 Main Street, E62-639 \\ Cambridge, MA 02142 \\ and NBER \\ xgiroud@mit.edu \\ Joshua Rauh \\ Stanford Graduate School of Business \\ Stanford University \\ Knight Management Center \\ 655 Knight Way \\ Stanford, CA 94305-7298 \\ and Hoover Institution \\ and also NBER \\ rauh@stanford.edu
}


The impact of state business taxation on employment and capital has been heavily debated in both academic and policy circles on both theoretical and empirical grounds. State-level business taxation could depress business activity through several channels. Businesses that might otherwise have hired or invested might simply not do so due to the difference between the pre-tax and after-tax profits, or alternatively business might move their activities to another U.S. state. On the other hand, increased business taxation might not have a negative effect on business activity if businesses can change their activities to use more tax-favored production strategies or organizational forms, or if tax revenues are spent on public goods that improve the state's business climate. As U.S. states face increasing fiscal pressures, the debate over the effects of state tax policy on state level business activity is likely to intensify.

An empirical literature beginning with Carlton (1979), Carlton (1983) and Barthik (1985), and surveyed in Barthik (1991), has studied the geographic location decisions of new firms or establishments as a function of state tax and other characteristics. ${ }^{1}$ Studies beginning with Helms (1985) and Wasylenko and McGuire (1985), and most recently Gale, Krupkin and Rueben (2015), have used aggregated panel data at the state, county, or industry level to examine the effect of state and local taxes on economic growth, employment, or capital formation. ${ }^{2}$

This line of work has faced two main challenges. First, tax policy is not exogenously determined, so that ascribing a causal interpretation to correlations between state tax changes and counts of businesses or employees has been problematic. The primary concern is that state governments might change tax policy in anticipation of changing economic conditions. Fox (1986), Holmes (1998), Holcombe and Lacombe (2004), and Ljungqvist and Smolyansky (2014) have taken one approach to addressing this question by using county-level data to study how state taxation or business climates affect business activity in border counties between states that change policy and those that do not. The second challenge is that the studies have lacked comprehensive micro-data at the establishment level, so that the decisions of individual busi-

\footnotetext{
${ }^{1}$ Other papers taking various approaches to measuring the effect of tax policy on the location of new plants or firms include Papke (1991), Wasylenko (1991), Coughlin, Terza, and Vachira (1991), Hines (1996), Guimaraes, Figueiredo, and Woodward (2003, 2004), Gabe and Bell (2004), Rathelot and Sillard (2008), and Brüllhart, Jametti, and Schmidheiny (2012).

${ }^{2}$ Earlier papers, focusing on one municipal or geographic area, include Grieson, Hamovitch, Levenson, and Morgenstern (1977) and Grieson (1980) on the New York City and Philadelphia income taxes respectively, Fox (1981) who examines Cuyahoga County, and Newman (1983) on the South. Papers following on the panel approach of Helms (1985) using aggregated panel data include Papke (1987), Mofidi and Stone (1990), Goolsbee and Maydew (2000), Bania, Gray, and Stone (2007), Reed (2008), Serrato and Zidar (2014), and Gale, Krupkin, and Rueben (2015).
} 
nesses cannot be tracked over time, leaving uncertainty as to whether firms are relocating their businesses to other regions or reducing the scale of their operations.

This study uses comprehensive and fully disaggregated establishment-level data from the U.S. Census Bureau to examine the impact of state business taxation on employment and capital. We focus on firms with establishments in multiple states. To identify an effect of state tax policy on establishment counts, employment, and capital, we begin by exploiting the fact that the corporate tax code only affects firms organized as subchapter $\mathrm{C}$ corporations, whereas firms organized as S corporations, partnerships, or sole proprietorships (so-called pass through entities) are only affected by the individual tax code and other business taxes. ${ }^{3}$

This setting allows for separate identification of the effects of the corporate tax code on the activities of $\mathrm{C}$ corporations, and of the effects of the personal tax code on the activities of pass through entities. Furthermore, the establishment-level micro data allow us to disentangle reallocation versus pure economic disincentives of taxation. Specifically, we examine whether firms increase their activities in a given state when taxes increase in the other states in which they are active.

We consider the complete sample of all U.S. establishments from 1977-2011 belonging to firms with at least 100 employees and having operations in at least two states. On the extensive margin, we find that a one percentage point increase (decrease) in the state corporate tax rate leads to the closing (opening) of 0.03 establishments belonging to firms organized as $\mathrm{C}$ corporations in the state. This corresponds to an average change in the number of establishments per $\mathrm{C}$ corporation of $0.4 \%{ }^{4}$ A similar analysis shows that a one percentage point change in the state personal tax rate affects the number of establishments in the state per pass-through entity by $0.2-0.3 \%$. These effects are robust to controls for local economic conditions and heterogeneous time trends. Opposite effects of around half of these magnitudes are observed in response to tax changes in the other states in which firms operate, so that around half of the baseline effect is offset by reallocation of activity across states. This lends strong support to the view that tax competition across states is economically relevant, and is consistent with findings by Davis

\footnotetext{
${ }^{3} \mathrm{C}$ corporations could of course also be affected by state-level personal taxes to the extent that the firm's owners are in-state and are subject to these taxes when removing equity from the firm. However, we find no evidence that the business activity of $\mathrm{C}$ corporations responds to state-level personal tax rates.

${ }^{4}$ The standard deviation of the change in the corporate income tax rate is 0.32 , so a one standard-deviation change in corporate income tax rates over this period had an effect of $0.10-0.15 \%$ on the number of establishments per C-corporation firm.
} 
and Haltiwanger (1992) that emphasize the importance in the labor market of shifts in the distribution of employment opportunities across work sites.

On the intensive margin, we find that the elasticity of $\mathrm{C}$ corporation employment for a given establishment is 0.4 with respect to the state corporate income tax rate, and the elasticity of pass-through business employment is 0.2 with respect to the personal income tax rate, while the cross-correlations are zero. That is, there is no empirical correlation in the data between changes in employment at an establishment belonging to a $\mathrm{C}$ corporation and the personal tax rate. Similarly there is no empirical correlation in the data between changes in employment at an establishment belonging to a pass-through entity and the corporate tax rate. This lack of cross-correlations supports the identifying assumption in these regressions that there are not state-level trends in general business activity around changes in tax policy.

Further analysis captures complexities, heterogeneity, and changes in state tax codes regarding apportionment of income in multi-state firms. If a company has physical presence in more than one state, the company has to apportion its profits according to each state's apportionment factor weights for property, payroll, and sales. Furthermore, if a state has throwback or throwout rules, companies that have sales in states where they do not have physical presence may need to apportion profits arising from those sales to states where they do. We show that the response of moving establishments and employees is greatest when those factors have greater apportionment weights. Even if the sales apportionment factor is large, we also find strong effects when throwback or throwout rules are in effect, as these rules mitigate the tax attractiveness of firms moving to high sales-apportionment states.

We examine whether there is any evidence of confounding differential trends in $\mathrm{C}$ corporations versus pass-through entities in the years leading up to tax changes in a subsample of firms affected by states that changed at least one of their tax rates by at least 100 basis points. These large tax changes occurred 161 times during the sample period. Here we find similar directional results of somewhat smaller magnitude, with no evidence of pre-trends. Around half of the effects are felt in the tax year in which the tax rate changed, with the full force being felt in the following year.

We further address legislative endogeneity concerns by adopting a narrative approach in the spirit of Romer and Romer (2010) with reference to these 161 large tax changes. By searching news articles in the year of each tax change and two years prior, we classify the changes according 
to the same categories as Romer and Romer (2010), treating those that were passed to deal with an inherited budget deficit or to achieve a long run goal as more likely uncorrelated with other factors that could affect output and economic activity. For these more likely exogenous changes, we find magnitudes very similar to those in the full sample of establishments affected by these large cuts.

In some instances around the Economic Recovery Tax Act of 1981 (ERTA81) and the Tax Reform Act of 1986 (TRA86), state tax policy changed only as a result of responses to windfalls or negative shocks to the state fiscal position caused by the federal legislation. ERTA81 implemented accelerated depreciation schedules, thereby reducing current tax revenues for many states that followed federal rules. To offset this reduction, four states increased the corporate income tax rate. The tax base broadening in TRA 86 created a positive windfall for many states that follow federal definitions of the tax base, and as a result 10 states and the District of Columbia reduced their personal tax rates (Ladd (1993)). For two states, Utah and Montana, TRA86 created a negative shock to the fiscal position, and these states raised their personal tax rates in response. We augment the narrative approach by looking separately at tax changes at the state level that occurred in response to these windfalls and shocks from ERTA81 and TRA86, finding effects of similar magnitude to the other large increases and cuts in the corporate and personal tax rates.

Analysis on the subset of the Census data on manufacturing firms allows us to consider the impact of state taxation on capital formation and location. We find that capital shows similar directional patterns to labor in its response to taxation, but that the elasticities are $36 \%$ smaller. Furthermore, the detailed data on the location of manufacturing firm property allow us (by way of apportionment formulas) to consider the impact of a state policy that raises the actual tax claim on a dollar of total corporate profit by one percentage point, as opposed to increases in the statutory rate by one percentage point. Under this definition, which captures cross-sectional firm heterogeneity in the extent to which statutory changes affect the tax burden, we find somewhat larger elasticities of around $0.4 \%$ for labor and $0.3 \%$ for capital.

One concern about the analysis might be that the results could be affected by firms that change their organizational form in response to changes in the tax code. Goolsbee (2004) finds using cross-state tax variation that the share of economic activity by firms in corporate form does in fact respond to the relative taxation of personal to corporate state income, by as much 
as $0.2-0.6 \%$ of state employment for a 1 percentage point change in the corporate rate relative to the personal rate. However, our sample in this paper consists only of firms with activity in more than one state, and firms must choose one organizational form that will be applicable to all entities. For these firms, federal tax policy should be far more important for the organizational form decision that the mix of state tax policies they face, a hypothesis we confirm in the data. Limiting the sample to the $92 \%$ of observations belonging to firms that do not change their organizational form within 5 years of tax changes leaves the results unaffected.

Our analysis controls for other state-level tax policy variables including unemployment insurance laws, state sales taxes, a coarse estimate of property tax burdens, and an index of business tax incentives. These are not the focus of our study, but the results on unemployment insurance (UI) are informative. We find that an increase in state UI rates by 100 basis points at the median UI base wage would decrease the number of establishments per firm in the treated state by -0.025 . Our analysis finds little impact of state sales taxes on the activity of sample firms.

Overall, our findings on the effects of corporate taxation are larger than those found in work that has examined the impact of tax policy at the national level, such as Mertens and Ravn (2013) who find using narrative approaches that a 1 percentage point cut in the average corporate income tax rate at the federal level raises employment by a maximum of 0.3 percent. Some of this difference may be attributable to differences in the measurement of corporate rates (average versus marginal), the level of analysis (state versus federal), the identification strategy and the distinction between GDP per capita and the variables we consider. That said, in our analysis, tax competition across states roughly doubles the baseline effects that would be found in the absence of firms' ability to move across states, and for that reason we would extrapolate that the impact of state policy on state business activity should be about double the impact of federal business taxation on federal business activity.

This paper is organized as follows. Section I reviews the background and related literature on business taxation at the state level. Section II discusses the data and methodology, specifically the establishment level data from the U.S. Census Bureau, our compilation of changes in state tax codes from 1977-2011, the specifications, and the implementation of the robustness checks using the narrative approach and the changes in state tax policy induced by federal legislation. Section III details the results on the extensive margin, that is, the number of establishments per firm in a given state as a function of state business tax policy. Section IV describes the effects of 
state tax policy on the intensive margin, specifically labor and capital inputs per establishment. Section V offers conclusions.

\section{Background and Related Literature}

\section{A. Business Taxation at the State Level}

In many respects, the structure of state business taxation follows the general outlines of federal tax law. The decision of a firm to incorporate allows for limited liability and centralized management, but opens the possibility of entity level taxation under the corporate tax code at the federal level (Congressional Budget Office (2012)). Firms that are incorporated under subchapter $\mathrm{C}$ of the federal tax code (C Corporations) must pay tax at corporation tax rates. Owners of these firms then pay individual taxes when they receive dividends from the $\mathrm{C}$ Corporations or when they realize capital gains. Firms that are incorporated under subchapter $\mathrm{S}$ of the federal tax code, as well as unincorporated firms organized as partnerships and sole proprietorships, are deemed pass-through entities. Pass-through entities pay no tax at the firm level, but rather pass all profits on to their owners, who must pay taxes immediately on their profits.

Firms also have the ability to organize as Limited Liability Corporations (LLCs), a structure which offers some of the benefits of corporate organization, without necessarily being subject to entity-level taxation under the federal corporate tax code. The first LLC was established in Wyoming in 1977, and IRS rulings in 1988 and 1996 clarified the conditions under which LLCs could choose pass-through taxation, with the latter ruling allowing a checkbox election for pass-through taxation (Congressional Budget Office (2012)). The CBO describes the LLC as "full liability protection in a non-corporate environment." The LLC is a more flexible form than the subchapter S corporation. LLCs are not subject to state-level governance and filing requirements for corporations, nor do LLCs have to allocate profits in proportion to ownership shares, as S corporations do (Congressional Budget Office (2012)).

Our main analysis makes use of these differences in taxation across organizational forms to identify the effects of state income taxation on the extensive and intensive margin. One concern might be that the results could be affected by firms that change their organizational form in response to the tax code. Gravelle and Kotlifkoff $(1988,1989,1993)$ argue that when firms can simply shift production across sectors, the deadweight loss from the corporate income tax can 
exceed 100 percent of the income generated. Results from Gordon and MacKie-Mason (1990, 1994, 1997) and Goolsbee (1998) suggests that across time periods there is little shifting of organizational form in response to tax rates. Goolsbee (2004) shows evidence that firms do in fact respond to state tax code by changing their organizational form. His estimates are that a 1 percentage point change in the corporate tax rate could reduce the corporate share of firms by $0.5-1 \%$ and the corporate share of sales and employment by $0.2-0.6 \%$, concluding that the effects are still "relatively modest."

We address this issue in several ways. First, we note that our analysis considers only firms with establishments in multiple states. As such, the effect of changing organizational form in response to state taxation is likely to be very muted in the firms in our sample, and explicit tests for this shifting in our sample confirms this. The organizational form of these firms is most likely determined more by federal tax policy than by the mix of state tax policies they face. Second, we provide evidence that there is essentially zero sensitivity of pass-through entity business activity (establishment counts, labor force, or capital stock) to corporate rates, and essentially zero sensitivity of corporate entity activity to personal rates. Firms only respond to changes in the tax code that is relevant for their organizational form as of the time of the tax change. Third, in robustness analysis, we show that excluding all observations that are within 5 years of a given firm's legal change of organization leaves our results unaffected.

Most states have a standard corporate income tax on profits that resembles the federal corporate income tax: taxable income is calculated starting with revenues net of allowable cost deductions, and then a corporate tax rate is applied. However, as of the end of our sample, three states had no corporate income tax, specifically Nevada, South Dakota, and Wyoming. ${ }^{5}$ Texas had no corporate income tax until 1991. Four states taxed corporations in some other way, usually a tax on gross receipts. Starting in 2005, Ohio began to phase out its corporate franchise tax and phased in a Commercial Activities Tax, which applies a rate of $0.26 \%$ to taxable gross receipts of over $\$ 1$ million. Michigan had a Single Business Tax based on a value-added calculation from 1975 onward. In 2008 it then began the phase-in of the Michigan Business Tax, which had a base of gross receipts less purchases, and then finally implemented a regular corporate income tax in 2012. Washington has the Business and Occupation Tax, a grossreceipts tax, during the entire sample period. Texas implemented a Corporate Franchise Tax

\footnotetext{
${ }^{5}$ Nevada, however, has a payroll tax called the Modified Business Tax (MBT). This tax is in addition to unemployment insurance contributions, which is also levied on payroll. This tax is not included in the analysis.
} 
in 1992, which was then replaced by the Texas Margin Tax in 2008. In the analysis we control for the periods where Ohio, Michigan, Texas, and Washington establishments were subject to these nonstandard forms of corporate taxation by using the appropriate state (or state by time period) indicator variables interacted with organizational form. ${ }^{6}$

Further complicating the analysis of the effects of tax policy on corporate activity are the laws that differ by state as to how taxable income must be apportioned for multi-state firms for tax purposes. In contrast to the federal tax treatment of multinational firms, which requires transfer prices for intermediate production inputs moved by the firm across borders, states use apportionment formulas that obviate the need for keeping track of internal prices. In determining state-level tax liabilities, a firm must first determine which states have the power to tax the business, or in tax terminology, whether a company has "nexus" in a state. A state only has taxation authority over a firm if the firm has physical presence in the state, specifically property or employees. The firm must then consider the apportionment formula for each state in which it has nexus.

Apportionment formulas are typically a function of the location of at least one of three different measures of economic activity: sales, payroll, and property. In essence the apportionment formula changes the corporate income tax into a tax on each of the apportionment formula factors (McLure (1980, 1981)). Gordon and Wilson (1986) show how apportionment approaches can create complex incentives both for multi-state firms and for state governments setting tax policy.

To illustrate by way of example, California had a one-third weight on each of sales, payroll, and property until 1992. That meant that a firm with nexus in California would calculate the share of sales, share of payroll, and share of property in California, and the average of these three components would yield the percent of the firm's taxable income apportioned to California. From 1992 to 2010, the weights in California were $50 \%$ on sales, $25 \%$ on payroll, and $25 \%$ on property ${ }^{7}$ so that relative to the previous regime, firms with more sales in California but less physical presence had to allow more of their income to be taxed in California. Conversely, firms with few in-state sales but more physical presence saw a reduction in their tax burden. These changes went even further in 2011, when California implemented a $100 \%$ weight on sales.

Under a pure "single-sales" apportionment factor, the only variable that would matter in

\footnotetext{
${ }^{6}$ Nevada also passed a modified gross receipts tax (the Commerce Tax) in 2015.

${ }^{7}$ This is sometimes referred to as a "double-weighted" sales apportionment factor.
} 
apportioning income to the state (assuming the firm has any physical presence) is what percent of the firm's sales were in the state itself. However, some states (including California) have socalled throwback rules associated with their apportionment calculations, where states capture income from sales to other states by requiring companies to add (or "throw back") sales that are to buyers in a state where the company has no nexus, or in a state where the company has nexus but there is no corporate income tax. Three states (Maine, New Jersey, and West Virginia) have a "throwout" rule instead of a "throwback" rule, which accomplishes a similar goal, namely to increase the relative weight of in-state sales in the sales factor, thus increasing the income apportioned to the taxing state. Under throwout rules, states capture income from the so-called "nowhere" sales by requiring companies to subtract (or "thow out") nowhere sales from total sales (i.e., in the denominator).

We include the impact of apportionment rules on the intensive and extensive margin of business activity in two ways. First, in the full sample, we study the interaction effect between the corporate tax rate and the sales weight adjusted for throwback and throwout rules. Indeed, the response of moving establishments and employees should be greatest when either the sales factor is small, or the sales factor is large but there is a throwback or throwout rule in place. This approach captures variation in state tax policy. It does not capture firm-level treatment heterogeneity in the extent to which different firms have different distributions of employees, property, and employees at the time of treatment.

This leads us to our second approach, which is only possible in the manufacturing sample due to the higher detail of the manufacturing data. While not available for non-manufacturing firms, the Census data on manufacturing firms show where a firm has property. We can therefore track all states in which manufacturing firms have nexus, and assign precise values of property shares and payroll shares in the calculation of apportionment-adjusted tax rates. ${ }^{8}$ The regression analysis in this case measures the firm's response to a change in the actual tax claim on a dollar of total (national) corporate profit by a given amount, e.g. a percentage point.

Businesses also pay an array of other taxes, notably sales taxes, unemployment insurance contributions, and property taxes. Furthermore, states often grant financial assistance for industry and tax incentives. These taxes are not the primary focus of our paper, but we do include

\footnotetext{
${ }^{8}$ The data do not allow us to observe the geographic distribution of the end point of each establishment's sales, requiring us to implement assumptions about the distribution of sales across states. We find the results are not sensitive to the exact method by which we allocate sales to different states under the apportionment formula.
} 
controls for all of these factors in our analysis.

\section{B. Relationship to Literature on the Effects of Business Taxation}

The earliest literature on the corporate income tax assessed its efficiency when the corporate sector produced one set of goods and the noncorporate sector another set of goods (Harberger (1962), Shoven (1976)). In these classic settings, the corporate income tax resulted in a redistribution of resources in the economy towards the goods produced by the noncorporate sector and therefore a deadweight loss. Gravelle and Kotlikoff (1989) examine efficiency costs of corporate taxation when corporate and noncorporate firms produce the same good, finding logically that such deadweight costs can be substantially higher. Goolsbee (2004) examines how firms adjust their organizational form with respect to state taxes at the corporate level, an adjustment margin that we also examine in our data. Since our sample firms all operate in multiple states, it is not surprising that we observe quite little leakage out of the corporate sector for these firms as a result of state-level tax policy.

A substantial literature has considered new business formation and how taxation affects the choice of where new firms decide to locate or where existing firms decide to open new establishments. Carlton (1979), Carlton (1983) and Barthik (1985) perform such analysis with conditional logits. Later studies along these lines include Papke (1991), Wasylenko (1991), Coughlin, Terza, and Vachira (1991), Hines (1996), Guimaraes, Figueiredo, and Woodward (2003, 2004), Gabe and Bell (2004), Rathelot and Sillard (2008), and Brüllhart, Jametti, and Schmidheiny (2012). This literature is unified by the use either of conditional logits or of count models to model the location of new plants or establishments.

Our paper is more similar to those that follow in the approach of Helms (1985), Wasylenko and McGuire (1985), Papke (1987), Goolsbee and Maydew (2000), Bania, Gray, and Stone (2007), and Reed (2008), which use panel data techniques on aggregated data. Our study is unique in that we use fully disaggregated data and distinguish between firms of different organizational form for tax purposes. We study not only the response of the level of in-state business activity, but also the extent to which firms reallocate across state boundaries.

Another feature of our analysis is that when we examine capital investment for manufacturing firms we are able to model the effect of apportionment formulas on the tax rate a firm faces by operating in a given state. There has been relatively little empirical work studying the impact of apportionment formulas. Using variation in the payroll weight across states and over 
time, Goolsbee and Maydew (2000) demonstrate that the within-state employment effect of reducing the payroll weight is on average substantial, but that such a change has a negative effect of employment in other states. Gupta and Mills (2002) find suggestive evidence that firms optimize reported sales locations in response to sales apportionment factors. Klassen and Shackelford (1998) find that manufacturing shipments from states that tax throwback sales are decreasing in corporate income tax rate on sales.

Serrato and Zidar (2014) exploit variation in both state corporate tax rates and apportionment rules to estimate the incidence of state corporate taxes on workers and owners in a spatial equilibrium model. Their main goal is to estimate the incidence of the corporate tax rate and welfare effects of tax policy changes, and they find that the incidence of the corporate tax falls $30-35 \%$ on workers.

Our paper is clearly related to the literature that explicitly attempts to measure a causal impact of taxation on economic growth and business activity. The primary concern in any specification that finds a correlation between taxes and growth or business activity is that there is omitted variables bias or reverse causality. Specifically, tax reforms might anticipate changes in growth, and this could bias coefficients either upwards (if tax cuts anticipate increases in business activity) or downwards (if tax cuts anticipate declines in business activity). Fox (1986), Holmes (1998), Holcombe and Lacombe (2004), and Ljungqvist and Smolyansky (2014) have taken one approach to addressing this question by using county-level data to study how state taxation or business climates affect business activity in border counties between states that change policy and those that do not. In contrast, our primary approach to this identification problem is to examine how $\mathrm{C}$ corporation activity changes differentially with respect to pass-through business activity in states that change either corporate or personal tax rates.

In further analysis, we also implement the so-called "narrative approach" which has become popular in the literature that examines the effect of national income taxes. Romer and Romer (2010) estimate the effects of changes in personal income taxes on GDP growth at the national level, and Mertens and Ravn (2013) extend this approach to study corporate taxes. In the narrative approach, tax changes are classified according to how likely they are to have been passed in anticipation of future economic conditions. In this literature, changes that are designed to deal with an inherited budget deficit or to achieve a long-run goal are viewed as more informative about the causal effect of business taxation on outcome variables, whereas those changes that 
offset changes in government spending or other output-related factors are viewed as endogenous.

Our headline estimates provide the response for the average change in spending that would accompany the tax increase. A state with a fiscally balanced budget that raises taxes to spend the proceeds on business development would probably see different responses compared to a state with an imbalanced budget, particularly if the state with the imbalanced budget raises taxes without any increase in spending that would attract businesses. To address this issue, we follow the Romer and Romer (2010) narrative approach in our robustness analysis, reading news coverage of tax changes and classifying them accordingly.

A further caveat is that our results average over differential tax treatment of different industries through different depreciation rules. Gravelle (1994) and Gruber and Rauh (2007) calculate marginal effective tax rates by industry as a function of depreciation rules and investment tax credits. The true incentive generated by tax policy is determined by the percent of expected return from new investment that would be collected by the government. Our underlying assumption is therefore that a one percentage point change in the statutory tax rate is accompanied by a one percentage point change in the effective tax rate, which will on average be the case if states are not simultaneously changing depreciation rules.

Finally, we note that we also include in the regressions measures of other types of taxes and tax rules, specifically sales taxes, property taxes, and targeted tax incentives. We consider these primarily as controls as our main goal is to estimate the effects of the income tax codes.

\section{Data and Methodology}

\section{A. Establishment-Level Data on Firm Business Activity}

The establishment-level data are obtained from the U.S. Census Bureau's Longitudinal Business Database (LBD). An establishment is a "single physical location where business is conducted" (Jarmin and Miranda (2003, p. 15)). The LBD covers all business establishments in the U.S. with at least one paid employee. For each establishment, the LBD includes data on employment, payroll, industry sector, location, and corporate affiliation.

We supplement the LBD with two other datasets from the U.S. Census Bureau: the Census of Manufactures (CMF) and the Annual Survey of Manufactures (ASM). The CMF covers all U.S. manufacturing establishments, referred to as "plants". The CMF is conducted every five 
years, in years ending with 2 and 7 (the so-called Census years). The ASM is conducted in all non-Census years and covers a subset of the plants covered by the CMF: plants with more than 250 employees are included in every ASM year, while plants with fewer employees are randomly selected every five years, where the probability of being selected is higher for relatively larger plants. Although the ASM is technically referred to as a survey, reporting is mandatory, and fines are levied for misreporting. The CMF and ASM contain detailed plant-level information such as capital expenditures, total assets, and the value of shipments. Accordingly, while the $\mathrm{ASM} / \mathrm{CMF}$ is less comprehensive than the LBD, it provides a richer set of establishment-level variables.

To create a primary sample for the analysis, we select all multi-unit companies in the LBD from 1977-2011 with at least 100 employees and establishments in at least two states. The rationales behind these selection criteria are that we are interested in medium-sized to large firms; and we are only interested in companies that consider multiple states in their location decisions. In this sample, we study the effects of taxation on establishment counts, establishment location, and employment. This primary sample consists of 27.6 million establishment-year observations, corresponding to 647,000 firm-year observations.

A secondary sample consists of those observations in the primary sample that are also in the ASM/CMF. This subsample allows us to study capital allocation decisions of firms in the Census, as the ASM/CMF data contain information on firm capital stock. We can therefore use this sample to study the effects of taxation on capital investment and location. This secondary sample consists of 854,700 establishment-year observations corresponding to 104,400 firm-year observations.

The LBD can be matched to the Census Bureau's SSEL (Standard Statistical Establishment List), which contains information from the Business Register. In particular, the SSEL provides a tax-based legal form of organization for all firms in the LBD. The identification of the legal form is based on the firm's tax filing status. Firms may be listed as having any one of seven possible legal forms: individual proprietorship, partnership, corporation, taxable cooperative association, tax-exempt cooperative association, government, or other legal form. ${ }^{9}$ In this study, we consider only the first three categories (i.e., sole proprietorships, partnerships, and corporations).

Importantly, the SSEL also contains the precise tax filing status of each company. Sole

\footnotetext{
${ }^{9}$ Establishments without payroll are classified into specified legal forms of organization according to the type of income tax form filed (1040C-individual proprietorship; 1065-partnership; 1120 and 1120S-corporation).
} 
proprietorships and partnerships are always pass-through entities for tax purposes, but firms organized as corporations can be designated for tax purposes as C-Corporations, which are subject to the corporate income tax, or S-Corporations, which pass through all profits to owners who then pay individual income tax and other business taxes. Corporations that designate themselves as LLCs can choose to file taxes as a partnership, C Corporation, or S Corporation. The LBD indicates the precise tax filing status of LLCs.

Figure 1 shows the percent of companies over time in the sample organized for tax purposes as C-Corporations and S-Corporations, as well as partnerships and sole proprietorships. The figure shows the downward trend in C-Corporations and the upward trend in the pass-through entities over time. This trend began in the early 1980s and accelerated with the passage of the Tax Reform Act of 1986, which made the tax code more favorable to pass-through entities by lowering federal individual tax rates below federal corporate rates. By 2011, 64\% of firms in our sample of multi-state firms were organized for tax purposes as C Corporations, $24 \%$ as $\mathrm{S}$ Corporations, and the remaining $12 \%$ as pass-through entities. This composition reflects the fact that multi-state businesses are much more likely to be organized as $\mathrm{C}$ Corporations than businesses operating in one state. According to 2007 statistics from the Congressional Budget Office (2012), 94\% of businesses in the US are organized as pass-through entities, although they account for only $38 \%$ of federal government business receipts.

Table 1 shows summary statistics for the sample in the paper at the different levels of observation used in our analysis. We note the Census Bureau requires us to round observation counts to the nearest hundred. Panel A shows the summary statistics at the establishment-year level, covering around 27.6 million observations. Here we can track the number of employees per establishment, and the capital stock of the 854,700 plant-year observations in the manufacturing sample. Panel B shows the summary statistics at the firm-state-year level. There are 4.2 million firm-state-year observations where firms have a nonzero number of establishments. At this level of observation, we can track the number of establishments a firm has in each state in each year; the number of employees a firm has in each state and each year; and the capital stock of each firm in each state in each year. If we expand the sample to 51 observations per firm year (50 states plus Washington DC), filling in the states where a firm has no business activities with zeros, the sample expands to about 33 million firm-state-year observations. The firm-state-year level of analysis is useful for our specifications that examine the extensive margin, whereas 
the establishment level of analysis is useful for studying the intensive margin. For completeness, Panel C aggregates the sample to the firm-year level, which shows that the sample covers 647,000 firm-year observations, 104,400 of which are in manufacturing. ${ }^{10}$

The average number of employees at an establishment in the LBD data is 50 for C-Corps and 36 for pass-through entities, while the median number of employees is $11 .^{11}$ The average number of establishments a firm has in a state, conditional on the firm being active in that state at all, is 7.1 for C-Corps and 3.7 for pass-through entities, while the medians are 1.3 establishments for C-Corps and 1.2 establishments for pass-through entities. The higher mean establishment and employee counts for C-Corps therefore arise primarily due to the right tail of the distribution of C-Corps, the largest of which may have thousands of employees in some establishments and hundreds of establishments in some states.

We also provide summary statistics for the capital stock of the manufacturing firms in the sample. Capital stock is calculated using the perpetual inventory formula. The appendix describes how capital stock is constructed from the CMF/ASM data. The within-industry variation in the capital stock variable is coming from each establishment's annually reported gross capital expenditures, as the depreciation rates used in the perpetual inventory formula are industryspecific.

\section{B. State Tax Codes (1977-2011) and Development of Explanatory Variables}

We compile data on many aspects of business taxation at the state level. We focus on the type of state corporate taxation, corporate tax rates, apportionment factors and throwback rules. We also collect data on sales taxes, unemployment insurance, personal income tax, property taxes, and tax incentives, which we include as control variables.

To characterize each state's corporate tax policy in each year, we obtain the type of state corporate taxation (whether regular corporate income tax, gross receipts tax, no tax, or other), and the corporate tax rates from three main sources: the University of Michigan Tax Database (1977-2002), the Tax Foundation (2000-2011), and the Book of States (primarily the chapter

\footnotetext{
${ }^{10}$ Note that our sample represents $12 \%$ of all establishments in the LBD, but less than $1 \%$ of all firms, as our sample selection criteria (multi-state firms with at least 100 employees) naturally overweight firms with more establishments.

${ }^{11}$ Due to the Census Bureau's disclosure policy, we cannot report median values. Instead, "median" in Table 1 refers to a pseudo-median that is computed as average across all observations between the 40th and 60th percentiles.
} 
"state finance"). ${ }^{12}$

Apportionment factors and throwback rules are obtained from the Commerce Clearing House's State Tax Handbooks. In our baseline analysis, we examine the sensitivity of business activity to the state tax rate $\tau_{C}^{i}$. Accordingly, our baseline estimates capture the average effect of state taxation across different apportionment regimes. In further analysis, we explicitly account for apportionment factors and throwback rules. We proceed in two ways.

In the first approach, we interact the state tax rate $\tau_{C}^{i}$ with a term that reflects the fact that larger sales apportionment factors dull the incentive for the firm to relocate plants and employees. This interaction term is either $\left(1-\alpha_{\text {sales }}^{i}\right)$, where $\alpha_{\text {sales }}^{i}$ is the sales apportionment factor, or $\left(1-\alpha_{\text {sales }}^{i}\left(1-I_{\text {throwback }}\right)\right)$ where $I_{\text {throwback }}$ is an indicator variable for whether the state has a throwback (or throwout) rule. Note that since the property and payroll apportionment factors are always equal, such specifications capture the full state-level heterogeneity in apportionment factors. The idea is that if a state has a 100\% sales apportionment factor and no throwback, firms would have little incentive to move property or plant across state borders in response to changes in $\tau_{C}^{i}$, as the location of firm property and plant would not affect taxes paid, assuming nexus is not changed. ${ }^{13}$ If a throwback rule is in place, then the tax rate would matter to the extent that the firm is selling in states with either no corporate tax or in which they have no nexus (property or employees).

In the second approach, we calculate apportionment-factor adjusted corporate tax rates for each state and firm. If a company has employees and property (nexus) in one state $(i)$ but sales in many states, all of the profits will be subject to the tax laws of state $i$, where it has the employees and property. In the absence of a throwback or throwout rule, the effective corporate tax rate in that state would be:

$$
\tau_{C(A F \text { adj })}=\tau_{C}^{i} \times\left[\begin{array}{c}
\alpha_{\text {payroll }}^{i} \times \frac{\text { payroll in } i}{\text { total payroll }}+\alpha_{\text {property }}^{i} \times \frac{\text { property in } i}{\text { total property }} \\
+\alpha_{\text {sales }}^{i} \times \frac{\text { shipments in } i}{\text { total shipments }}
\end{array}\right]
$$

\footnotetext{
${ }^{12}$ The data are available from:

http://www.bus.umich.edu/otpr/otpr/default.asp;

http://taxfoundation.org/article/state-corporate-income-tax-rates;

http://knowledgecenter.csg.org/kc/category/content-type/bos-archive.

${ }^{13} \mathrm{~A}$ caveat to this is that even if there is a $100 \%$ sales apportionment formula and no throwback, changes in the rate might give firms the incentive to move in or out of a state entirely. For example, a firm producing solely in Nevada and shipping only to California owes no corporate tax. But once it moves even a small number of employees to California, it has nexus in California and then must pay California income taxes.
} 
and analogously for the personal tax rate that applies to pass-through entities. So the company would at first glance appear to have a break in state $i$, getting a lower effective tax rate than the state's corporate tax rate $\left(\tau_{C}^{i}\right)$ based on the fact that it was selling outside of state $i$. However, if state $i$ has a throwback rule, all "nowhere" sales (sales to states where the firm's activities are not taxed because the firm has no physical presence there or because the state has no corporate tax) must be added into the final term of the formula:

$$
\tau_{C}^{i} \times\left[\begin{array}{c}
\alpha_{\text {payroll }}^{i} \times \frac{\text { payroll in } i}{\text { total payroll }}+\alpha_{\text {property }}^{i} \times \frac{\text { property in } i}{\text { total property }} \\
+\alpha_{\text {sales }}^{i} \times \frac{\text { shipments in i } i+\text { nowhere sales }}{\text { total shipments }}
\end{array}\right]
$$

If instead the state has a throwout rule, the nowhere sales must be subtracted from the denominator:

$$
\tau_{C}^{i} \times\left[\begin{array}{c}
\alpha_{\text {payroll }}^{i} \times \frac{\text { payroll in } i}{\text { total payroll }}+\alpha_{\text {property }}^{i} \times \frac{\text { property in } i}{\text { total property }} \\
+\alpha_{\text {sales }}^{i} \times \frac{\text { shipments in } i}{\text { total shipments }- \text { nowhere sales }}
\end{array}\right]
$$

We are not able to compute "nowhere sales" since we only observe the shipments generated by each establishment, not the geographical distribution of those shipments. The calculation of an apportionment- and throwback-adjusted effective tax rate therefore requires an assumption about the location of the shipments. In this specification, we assume that all the shipments of the plant go to states where the firm has no nexus, or states where there is no corporate tax. The effective tax rate we implement in this case is

$$
\tau_{C(A F \text { and } T B \text { adj })}=\tau_{C}^{i} \times\left[\begin{array}{c}
\alpha_{\text {payroll }}^{i} \times \frac{\text { payroll in } i}{\text { total payroll }}+\alpha_{\text {property }}^{i} \times \frac{\text { property in } i}{\text { total property }} \\
+\alpha_{\text {sales }}^{i} \times I_{\text {throwback }}
\end{array}\right]
$$

The other tax variables are obtained from a variety of sources. Personal income tax rates, which apply to the pass-through entities, are obtained from the NBER database of state-level tax rates. Sales tax rates are obtained from the University of Michigan Tax Database for 1977-2002 and from the Tax Foundation for 2000-2011. ${ }^{14}$ Unemployment insurance (UI) provisions are obtained from the Department of Labor's "Significant Provisions of State UI Laws." 15 The main

\footnotetext{
${ }^{14}$ The data are available from: http://www.bus.umich.edu/otpr/otpr/default.asp; http://taxfoundation.org/article/state-sales-gasoline-cigarette-and-alcohol-tax-rates.

${ }^{15} \mathrm{http}: / /$ www.unemploymentinsurance.doleta.gov/unemploy/statelaws.asp
} 
UI data we collect are on the UI base (or the amount of wages that is UI-taxable) and the UI rate. In our regression analysis, we calculate the UI contribution as the UI base times the UI rate, and estimate specifications with the log of this UI contribution as an explanatory control variable. ${ }^{16}$

As we were unable to obtain data on property tax rates that could be matched with business ownership of property, we instead use the total amount of property taxes collected by state and local governments in the establishment's state divided by total revenues of state and local governments in the establishment's state as a control variable called property tax share in the analysis. These data are available from the Census of Government State \& Local Finances. ${ }^{17}$ We emphasize that these are rough measures of the property tax burden in a given state that we include as a control, with the goal being to control for possible correlations between the income tax variables that are our primary objects of inquiry and other aspects of the business tax climate that operate through taxes on bases other than income.

Finally, we also collect and control for 33 targeted business incentives that are compiled annually by the magazine Site Selection (formerly Site Selection and Industrial Development Handbook). ${ }^{18}$ The business incentives are grouped into two categories: 18 different types of financial assistance for industry (FA) and 15 different types of tax incentives (TI). Common examples of financial assistance include the existence of a state-sponsored industrial development authority and state or local incentives for establishing industrial plants in areas of high unemployment. Common tax incentives include corporate or personal income tax incentives for new businesses or businesses in certain industries, and tax exemptions or moratoria on various factors of production such as land, capital, equipment, or machinery. For each state-year, we construct an index that adds one index point for each of the 33 business incentives. ${ }^{19}$ We label this index tax incentives index.

Table 2 shows the summary statistics for these tax variables at the state-year level from 19772011. Washington DC is also included, so the total observations are 35 years $\times 51$ states $=1,785$. The table shows that the mean corporate tax rate for the state-year observations in the sample

\footnotetext{
${ }^{16}$ The data include additional information, e.g., the amount of weekly earnings that are disregarded, the number of benefit weeks, etc. In the analysis, we abstract from these nuances of the UI calculations.

${ }^{17}$ http://www.census.gov/govs/local/

${ }^{18}$ http://www.siteselection.com/

${ }^{19}$ The Site Selection data are not available in all years. To fill in the missing years, we use the latest available year.
} 
is $6.85 \%$ and the mean personal tax rate is $5.29 \%$, with medians slightly higher in each case. The property tax share is on average $12 \%$ of total state and local government revenues. Sales tax rates are $4.4 \%$ at the mean and $5 \%$ at the median. The average unemployment insurance contribution across the state-year observations in the analysis is $\$ 699$ per worker. States generally set the payroll and property apportionment factors equal to each other, as reflected by the identical summary statistics on these apportionment factors. At the median the payroll, property, and sales apportionment factors are $1 / 3$, whereas at the mean the distribution is closer to $50 \%$ for sales, $25 \%$ for payroll, and $25 \%$ for property. $60 \%$ of state-year observations have a throwback rule.

Figure 2 shows the evolution of the distribution of corporate and personal income tax rates over time. Panel A shows that state corporate tax rates generally rose during the 1970s and 1980s, and generally fell during the 1990s and early 2000s, with the median corporate rate ticking up in 2011. The distribution of personal income tax rates as shown in Panel B behaved differently. The mean remained between $5.0 \%$ and $5.5 \%$ during the sample period, but the distribution across states becomes more compressed over time. These patterns are further illustrated in Figure 3, where increases and decreases in each tax rate are counted by year in histograms. Again one sees that the 1970s and 1980s generally saw more corporate tax increases, and the 1990s and 2000s more decreases. Panel B of Figure 3 shows that changes in the personal tax rates were overall more common than changes in the corporate rates, and decreases in personal tax rates during the final decade of the sample were particularly common.

Since our identification strategy relies on comparing firms with different legal forms of organization and tax filing statuses, it is important that there is sufficient independent variation in the corporate and personal tax codes. In Table 3, we analyze correlations among changes in the tax variables. The top panel shows correlations in levels. The corporate income tax rate and the personal income tax rate have a correlation of 0.21 . However, the bottom panel shows that in first differences, there is substantially less correlation, with the aforementioned figure falling to 0.04 .

Figure 4 further investigates the correlations between the corporate and individual tax rates. The upper panel of Figure 4 provides a scatter plot of the personal income tax rate (vertical axis) and corporate income tax rate (horizontal axis) across all state-year observations from 19772011. The bottom panel provides a scatter plot of the year-to-year changes (first differences) 
in the personal and corporate income tax rates. Here again, it is clear that in levels, states with higher personal income tax rates tend to have higher corporate income tax rates. The bottom panel, however, reveals many observations where only one rate was changed, or where there are increases in one rate and decreases in the other, with only weak evidence of positive correlation. We conclude from this analysis that when including state fixed effects, there is substantial variation that allows a separate effect to be measured of corporate versus individual tax rates.

\section{Specifications}

The first set of extensive-margin specifications examines the relation between state tax rates and the number of establishments a firm has in each state in each year. We estimate these specifications at the firm-state-year level in the sample of 32,997,200 firm-state-year observations, which includes zeros for states that have no observations in a given state in a given year. The dependent variable is the number of establishments firm $i$ has in state $s$ in year $t$. At a minimum, these specifications all contain both year fixed effects and firm-state fixed effects. The primary linear specification is therefore:

$$
\begin{aligned}
\# \text { Establishments }_{i s t}= & \alpha_{i s}+\alpha_{t}+\beta_{C, C}\left(\tau_{C} \times \text { CCorp }\right)+\beta_{P, P}\left(\tau_{P} \times \text { PassThrough }\right) \\
& +\beta_{C, P}\left(\tau_{C} \times \text { PassThrough }\right)+\beta_{P, C}\left(\tau_{P} \times \text { CCorp }\right) \\
& +\gamma \text { CCorp }+\Gamma^{\prime} \mathbf{X}+\varepsilon_{i s t}
\end{aligned}
$$

where $i$ indexes firms, $s$ indexes states, and $t$ indexes years. The variables $\tau_{C}$ and $\tau_{P}$ represent the state-level corporate and personal tax rates respectively, and $\mathbf{X}$ is a vector of other tax climate variables and controls including the sales tax rate, the log of the UI contribution, the property tax share, the tax incentives index, and the log of state-level GDP (obtained from the Bureau of Economic Analysis). The variable CCorp is an indicator variable equal to one if the establishment belongs to a firm that is a C-Corp, and the variable PassThrough is an indicator variable equal to one if the establishment belongs to a firm that is a pass-through entity. ${ }^{20}$

The key coefficients of interest are $\beta_{C, C}$ and $\beta_{P, P}$. These represent the effect of a one percentage point change in the corporate tax rate on the number of C-Corp establishments

\footnotetext{
${ }^{20}$ If firms never changed their form of incorporation, there would be no variation in CCorp within firm-state cells over time, and this term would drop out of the equation.
} 
in the state, and the effect of a one percentage point change in the personal tax rate on the number of pass-through establishments in the state, respectively. The cross-terms $\beta_{C, P}$ and $\beta_{P, C}$ can be thought of as measuring placebo effects. $\beta_{C, P}$ reflects the correlation between the corporate tax rate and the number of pass-through establishments in the state, and $\beta_{P, C}$ reflects the correlation between the personal rate and the number of corporate establishments in the state. We are testing the null hypotheses that each of the four betas is zero. If the identification strategy is sound and there is an effect of business taxation on the number of establishments in a given state, we expect to reject the null hypotheses that $\beta_{C, C}=0$ and $\beta_{P, P}$ $=0$, but not to reject the null hypotheses that $\beta_{C, P}=0$ and $\beta_{P, C}=0$. We also estimate a number of robustness specifications that include regional trends and industry trends, which are implemented by including interactions of those variables with year fixed effects.

Linear specifications have drawbacks when applied to count data (Hausman, Hall, and Griliches (1984)), so we also employ Poisson regressions, in which the count dependent variable is assumed to have a Poisson distribution, and estimate analogous coefficients. In addition, in keeping with the earlier literature on the location decisions of (primarily new) firms, we estimate conditional logit specifications. In order to map our setting into an outcome variable that takes a value of either zero or one, we define the dependent variable as an indicator for whether state $s$ had the largest increase in the number of establishments by firm $i$ in year $t$. In an analogous specification, we define the dependent variable as an indicator for whether the state $s$ had the largest decrease in the number of establishments by firm $i$ in year $t$.

One concern with the strategy of relying on differences in tax filing status to identify an effect is the possibility that tax filing status could be endogenous to the state corporate tax code. As a first point, it seems unlikely that the state corporate tax code is determining the tax filing status of multi-state companies, given the relative importance of this decision for the firm's liability under the federal tax code. However, we address this possibility in several ways.

First we estimate specifications where we exclude all firms that changed their legal form of organization (LFO) within a five year window around the tax change. Second, we estimate specifications that include LFO-by-year fixed effects, thus accounting for trends in legal form of organization around tax changes. Third, we test the hypothesis that state-level tax variables matter little for the organizational form decision for firms by running the following regression 
at the firm level

$$
1\left(\operatorname{CCorp}_{i t}\right)=\alpha_{i}+\alpha_{t}+\beta_{C}\left(\overline{\tau_{C}}\right)+\beta_{P}\left(\overline{\tau_{P}}\right)+\Gamma^{\prime} \mathbf{X}+\varepsilon_{i t},
$$

where the dependent variable is an indicator variable that equals one if the firm is a C-Corp, and the tax variables are the average tax rates across states where firm $i$ has establishments. We find no evidence of an effect of these rates on the firm decision to change its legal form of organization.

A further general critique that has been brought against studies that rely on variation in policy parameters is that firms may plan their investment, employment, and location decisions in part in expectation of future changes in government policy (Lucas (1976), or more recently Hennessy and Strebulaev (2015)). For example, if firms expect taxes to increase at date $t$ and then taxes do increase at that date but by less than expected, the tax increase would in effect amount to a tax cut relative to expectations, making estimated coefficients difficult to interpret.

One approach we take to address this question is to estimate predicted values of corporate and personal tax rates based on one-year lags of those tax rates and other macroeconomic variables:

$\tau_{C, t}=\alpha+\lambda_{1} \tau_{C, t-1}+\lambda_{2} \log (G D P)_{t-1}+\lambda_{3}$ UnemploymentRate $_{t-1}+\lambda_{4} \%$ Budget Surplus $_{t-1}+\epsilon_{\tau(C)}$

$\tau_{P, t}=\alpha+\lambda_{1} \tau_{P, t-1}+\lambda_{2} \log (G D P)_{t-1}+\lambda_{3}$ UnemploymentRate $_{t-1}+\lambda_{4} \%$ BudgetSurplus $_{t-1}+\epsilon_{\tau(P)}$

where \%BudgetSurplus is calculated as $\frac{\text { Revenues - Expenditures }}{\text { Expenditures }}$ at the state level using data from the Census of Governments State \& Local Finances, and the state-level unemployment rate is obtained from the Bureau of Labor Statistics. We then re-estimate our primary specifications using $\epsilon_{\tau(C)}$ instead of $\tau_{C}$ and $\epsilon_{\tau(P)}$ instead of $\tau_{P}$. This can then be thought of as the effects of tax changes that would be unpredictable by the simple lag regression model above.

To establish how much of the measured effects are due to reallocation to other states, we also estimate a version of our equation (3), but including a set of tax variables set equal to the 
average tax rates in all other states in which the company has operations:

$$
\begin{aligned}
\text { \# Establishments } s_{i s t}= & \alpha_{i s}+\alpha_{t}+\beta_{C, C}\left(\tau_{C} \times \text { CCorp }\right)+\beta_{P, P}\left(\tau_{P} \times \text { PassThrough }\right) \\
& +\beta_{C, P}\left(\tau_{C} \times \text { PassThrough }\right)+\beta_{P, C}\left(\tau_{P} \times \text { CCorp }\right) \\
& +\varphi_{C, C}\left(\widetilde{\tau}_{C,-s} \times \text { CCorp }\right)+\varphi_{P, P}\left(\widetilde{\tau}_{P,-s} \times \text { PassThrough }\right) \\
& +\varphi_{C, P}\left(\widetilde{\tau}_{C,-s} \times \text { PassThrough }\right)+\varphi_{P, C}\left(\widetilde{\tau}_{P,-s} \times \text { CCorp }\right) \\
& +\gamma \text { CCorp }+\Gamma^{\prime} \mathbf{X}+\varepsilon_{i s t},
\end{aligned}
$$

where the tax variables with tildes are the average rates for all other states except state $s$. The variables $\varphi_{C, C}$ and $\varphi_{P, P}$ measure the impact of the change in the average tax rates in other states the firm is active in on the number of establishments in state $s$ itself.

Finally, our intensive margin specifications are analogous to the extensive margin equations. Specifically, we estimate

$$
\begin{aligned}
\log \left(\text { employees }_{i t}\right)= & \alpha_{i}+\alpha_{t}+\beta_{C, C}\left(\tau_{C} \times \text { CCorp }\right)+\beta_{P, P}\left(\tau_{P} \times \text { PassThrough }\right) \\
& +\beta_{C, P}\left(\tau_{C} \times \text { PassThrough }\right)+\beta_{P, C}\left(\tau_{P} \times \text { CCorp }\right) \\
& +\gamma \text { CCorp }+\Gamma^{\prime} \mathbf{X}+\varepsilon_{i t}
\end{aligned}
$$

in the full LBD at the establishment-year level, with establishment and year fixed effects, $\alpha_{i}$ and $\alpha_{t}$, respectively. Similarly, in the manufacturing subsample, we estimate equation (7) using as dependent variable $\log \left(\right.$ capital $\left._{i t}\right)$ to examine capital formation effects.

\section{Narrative Approach}

In an extension of our analysis, we study a subsample of firms affected by states that changed one of their tax rates by at least 100 basis points. These large tax changes - which we refer to as "treatments" - occurred 161 times during the sample period. We distinguish between four types of treatments: large increases in $\tau_{C}$, large decreases in $\tau_{C}$, large increases in $\tau_{P}$, and large decreases in $\tau_{P}$.

For each treatment category, we restrict the sample to firms in the treated states three years before and three years after the treatment. ${ }^{21}$ We then estimate the following difference-

\footnotetext{
${ }^{21}$ We restrict the treatment window to ensure that our analysis is not affected by multiple treatments or treatment reversals.
} 
in-differences specification:

$$
\# \text { Establishments } s_{i s t}=\alpha_{i s}+\alpha_{t}+\beta \times \text { Treatment }+\Gamma^{\prime} \mathbf{X}+\varepsilon_{i s t}
$$

where Treatment is the treatment dummy that equals one for treated firms in the years following the treatment. When changes in $\tau_{C}$ are considered, the treatment group consists of C-Corps and the control group of pass-through entities (the other way around for changes in $\tau_{P}$ ). In spirit, this specification is closest to our ideal experiment - we vary a tax parameter and then study the differential response of C-Corps and pass-through entities within the same state.

An appealing feature of specification (8) is that it allows us to examine the dynamics of the treatment. Specifically, we estimate a variant this specification replacing the treatment dummy with a set of indicator variables that capture the dynamics of the large tax changes (e.g., one year before the treatment, year of the treatment, one year after the treatment, etc.). If our results are driven by pre-existing trends, we should observe an "effect" of the tax changes before they are even implemented.

Another appealing feature of specification (8) is that it can be used to implement the narrative approach of Romer and Romer (2010). They note that most tax changes have a single, clearly identifiable motivation that falls into one of four broad categories: (1) offsetting a change in government spending; (2) offsetting some factor other than spending likely to affect output in the near future; (3) dealing with an inherited budget deficit; (4) achieving some long-run goal, such as higher normal growth, increased fairness, or a smaller role for government. Romer and Romer (2010) classify (1) and (2) as "endogenous," and (3) and (4) as "exogenous".

Romer and Romer's (2010) analysis pertains to changes in federal tax rates. We adopt their approach with reference to our 161 large tax changes at the state level. Specifically, we search for news articles in the year of each tax change and two years prior. We then classify the changes according to the same categories as Romer and Romer (2010).

Finding newspaper coverage of state-level tax changes is no easy task. Electronic archives of local newspapers often do not go back to the 1980s, while large out-of-state newspapers, such as the Wall Street Journal and the New York Times, often provide no coverage, especially for small states. After a careful search of major newspaper databases (Factiva, Lexis-Nexis, Newsbank America's Newspapers, and Access Newspaper Archive Pro), we could find newspaper coverage for 107 out of the 161 large tax changes. The majority (83) falls into the exogenous subcategories. 
We then estimate a variant of specification (8) where we decompose the treatment dummy into Treatment (exogenous), Treatment (endogenous), and Treatment (unclassified).

Despite its appeal, a drawback of the narrative approach is that it is inherently subjective. To alleviate this concern, we identify a subset of tax changes that are likely exogenous on objective grounds. Specifically, we exploit two federal reforms - the Economic Recovery Tax Act of 1981 (ERTA81) and the Tax Reform Act of 1986 (TRA86) - that triggered changes in state tax policies. ERTA81 implemented the accelerated cost recovery system (ACRS). Effectively, ARCS accelerated depreciation schedules, thereby reducing tax revenues for states that followed federal rules. To offset this reduction, four states (Indiana, Iowa, Nebraska, and Wisconsin) increased their corporate income tax (Aronson and Hilley (1986)).

Similarly, TRA86 broadened the tax base for the federal income tax, thus creating a revenue windfall for states that follow the federal definition of the tax base. As a result, 10 states (California, Delaware, Kansas, Maine, New York, Ohio, Oregon, Rhode Island, Vermont, and West Virginia) and D.C. reduced their personal income tax (Ladd (1993)). For two states, Utah and Montana, the reform created a negative shock to the fiscal position, and these states raised their personal income tax in response. In the analysis, we account for these federal tax reforms by decomposing the Treatment (exogenous) dummy into the three dummies Treatment (ERTA81), Treatment (TRA86), and Treatment (other exogenous).

\section{Results}

\section{A. Effect of State Tax Rates on the Counts and Locations of Establishments and Employees}

This section presents the results of the analysis we conduct on the extensive margin. That is, how do changes in the state tax code affect the number of establishments a firm has in a given state. In Table 4 we analyze this question at the level of the firm-state-year. As illustrated in equation (3), the dependent variable is the number of establishments each firm has in each state in each year, where that value equals zero if an active company has no observations in the state. Column (1) shows the results without a control for $\log (G D P)$ and column (2) shows the results in the presence of such a control.

Including the $\log (G D P)$ term has the obvious advantage that it prevents the regression from attributing any changes in establishment counts to changes in economic activity that might 
be unrelated to tax policy. On the other hand, including the control is tantamount to the assumption that the changes in economic activity had nothing to do with the tax policy itself. If tax policy affects GDP growth and does so in part through the effects of tax policy on business activity, then controlling for GDP will lead to an underestimate of the true effect of the tax policy. To be cautious, we nevertheless focus on the results that include GDP controls.

Controlling for GDP, the point estimates are $\beta_{C, C}=-0.031$ and $\beta_{P, P}=-0.010$. Both are statistically significant at the $1 \%$ level, with standard errors clustered by state. This means that a 100 basis point increase in the corporate tax rate would lead to the closure of 0.31 establishments per C-Corp firm in a given state, out of an average of 7.06 establishments per state per C-Corp firm as shown in Table 1. A 100 basis point increase in the personal tax rate would lead to the closure of 0.10 establishments, compared to an average of 3.72 establishments per state per pass-through entity as shown in Table 1. These coefficients therefore imply that a 100 basis point increase (decrease) in the statutory corporate income tax rate corresponds to a $0.44 \%$ decrease (increase) in the number of establishments belonging to corporations. A 100 basis point increase (decrease) in the statutory personal income tax rate corresponds to a $0.27 \%$ decrease (increase) in the number of establishments belonging to pass-through firms.

The coefficients on the key tax variables in the Poisson specification in column (3) are around 20-30\% smaller than in the preferred linear specification in column (2). In Appendix Table A1 we present conditional logit results, defining the binary dependent variable as being either the state with the largest increase in the number of establishments for a given firm in a given year, or the largest decrease in the number of establishments. We find that for each 100 basis point increase in the corporate tax rate, a given state is $0.4 \%$ less likely to be the state in which a corporate firm has the largest increase in the number of corporate establishments for that firm in that year. For each 100 basis point increase in the personal tax rate, a given state is $0.3 \%$ less likely to be the state in which a pass-through firm has the largest increase in the number of pass-through establishments for that firm in that year. The parallel specifications that examine the likelihood of being the state with the largest decrease have inverse though somewhat weaker results.

In the above discussion we focused for simplicity on changes of 100 basis points. A 100 basis point change in tax rates is considerably higher than the standard deviation of the change in rates. A one standard deviation change in the corporate income tax rate is 32 basis points 
and a one standard deviation change in the personal income rate is 53 basis points. So a one standard deviation change in $\tau_{C}$ corresponds to a $0.14 \%(=0.44 \% \times 0.43)$ change in the number of corporate establishments and a one standard deviation change in $\tau_{P}$ also corresponds to a $0.14 \%(=0.27 \% \times 0.53)$ change in the number of pass-through establishments.

The coefficients $\beta_{C, P}$ and $\beta_{P, C}$ are economically negligible and statistically insignificant, so that we reject neither of the null hypotheses regarding the cross terms. That is, we do not reject the nulls that $\beta_{C, P}=0$ and $\beta_{P, C}=0$. This is important for our analysis as it suggests that $\beta_{C, C}$ and $\beta_{P, P}$ are actually reflecting responses to the tax rates, not spurious correlations. We can conclude that if there are omitted factors driving both tax policy and the number of firm establishments in a state over time, then there now have to be separate omitted factors explaining why corporate tax policy is correlated with C-Corp business activity and not with pass-through business activity, and why personal income tax rates are correlated with pass-through business activity but not corporate activity. Furthermore, the fact that we include all four terms in the same regression allows corporate business activity to serve as a control for pass-through business activity around changes in the personal tax rate, and pass-through business activity to serve as a control for corporate business activity around changes in the corporate tax rate.

Since this specification includes firm-by-state fixed effects and the legal form of organization is constant within a firm across states, the indicator CCorp reflects the change in the number of establishments when a firm changes its legal form of organization. We address concerns about whether such changes in legal forms of organization could be driving the results in the next table. Here we note that when companies change to C-Corp status, there is a substantial increase in the number of establishments, which is intuitive as C-Corp status will typically only make sense for larger firms and particularly those with dispersed ownership, which in some cases (e.g., publicly traded corporations) will be required to organize as C-Corps.

While we view the other tax items primarily as controls in the analysis of the effect of the income tax variables, it is nonetheless instructive to consider their magnitude. In this specification, the sales tax rate has no measured impact on the number of establishments, but UI policy and the property tax share do have statistically significant effects. For UI, the effect is best explained by considering the mean values of the inputs and then calculating the comparative static of changing the UI rate by a certain number of basis points. The mean UI base wage is $\$ 10,658$ and the mean UI tax rate is $6.47 \%$, so the $\log$ of these means is $\log (10,658 \times 6.47 \%)=$ 
6.54. ${ }^{22}$ An increase in the UI rate by 100 basis points will increase the log of the UI contribution by 0.14 . Since the coefficient in column (2) is -0.183 , this implies a 100 basis point increase in the UI tax rate would lead to a decrease in the number of establishments by $-0.183 \times 0.14$ $=-0.026$ establishments, a magnitude that is between that of the coefficients $\beta_{P, P}=-0.010$ and $\beta_{C, C}=-0.031$ above. The property tax share variable indicates that companies have fewer establishments in states with a greater property tax burden. A one-standard deviation (0.05) increase in the property-tax share variable is correlated with 0.018 fewer establishments.

In Table 5 we conduct robustness analysis on the extensive margin. The first column includes region-by-year fixed effects, to control for possible correlations between shifts in the regional composition of establishments over time and state tax policy. ${ }^{23}$ So for example, if tax rates moved relatively lower over time in the Mountain region, while economic activity was on a general upward trend in this region, specifications without region-by-year fixed effects would attribute all of the increase in economic activity to the tax policy and not to secular regional effects. We find that the inclusion of regional trends if anything strengthens the results.

The second column of Table 5 includes industry-by-year fixed effects, to control for possible correlations between shifts in the industry composition of establishments over time and state tax policy. So for example, if tax rates moved relatively higher in states that had industries in decline for unrelated reasons, specifications without industry-by-year fixed effects would attribute all of the decrease in economic activity to the tax policy and not to the industry declines. The inclusion of industry trends reduces the magnitude of the corporate tax coefficient from 0.031 to 0.026 , and the personal tax coefficient from 0.010 to 0.006 . Industries are measured at the two-digit SIC level, so in this specification all variation that is due to changes in the industry composition of economic activity at the state level is absorbed.

The next two columns address the changing composition of legal forms of organization and the possibility of endogeneity with respect to state tax policy. Column (3) includes trends in the legal form of organization interacted with year fixed effects, to allow C-Corps and passthrough entities to have differential changes in the number of U.S. establishments each year. This addresses the possibility that corporate tax reforms might take place at times when C-

\footnotetext{
${ }^{22}$ Note that this is larger than the average of the log UI contribution shown in Table 2, due simply to Jensen's Inequality.

${ }^{23}$ The regions are the 9 Census regions: Pacific, Mountain, West North Central, East North Central, West South Central, East South Central, South Atlantic, Middle Atlantic, and New England.
} 
Corp activity would have declined independent of the tax reform. Column (4) excludes all observations within a 5-year window around any change in the legal form of organization, and the results remain robust.

In Appendix Table A2 we directly address the question of changes in legal form of organization by showing the results of a linear probability model at the firm-year level, where the explanatory variables are the tax variables, computed as (employee-weighted) averages across all states where the firm has establishments. Each year, $1.4 \%$ of C-Corps become pass-through entities and $1.1 \%$ of pass-through entities become C-Corps. We find that the state-level tax variables have no statistically significant effect on the likelihood of changing organizational form, except that fewer state-level tax incentives may marginally increase the probability of being a C-Corp. Since firms must choose one organizational form for the entire firm, it is reasonable to believe that federal tax policy has the strongest effect here.

Column (5) of Table 5 uses the residuals from predictive regressions shown in equation (5) above, instead of the tax variables $\tau_{C}$ and $\tau_{P}$ themselves. Appendix Table A3 shows the results of the predictive regression itself. ${ }^{24}$ The only variation that is used in the residuals is variation that is not predicted by lagged values of the tax variables, GDP, the unemployment rate, and the state budget percent surplus or deficit. Using only this unpredicted component does not change the results appreciably from the baseline.

Column (6) shows the results only for the manufacturing subsample. Here we find that the effects of tax policy on C-Corps are smaller than in the full sample. For example, $\beta_{C, C}$ declines from -0.031 to -0.019 , possibly reflecting the high fixed costs of establishing and moving manufacturing establishments.

Finally, in Column (7), the dependent variable is a dummy variable indicating whether the company has at least one establishment in the state - that is, this specification is a linear probability model that examines whether state taxation affects companies at the "extensiveextensive margin". The overall pattern is again similar. Specifically, we find that a 100 basis point increase in the corporate (personal) income tax rate reduces the probability of C-Corps (pass-through businesses) having any operations in the state by $0.3 \%(0.2 \%)$.

Table 6 augments the extensive margin regressions with the tax policies of other states in

\footnotetext{
${ }^{24}$ Appendix Table A3 indicates that corporate tax rate increases are weakly correlated with higher lagged GDP growth and a lower lagged unemployment rate, whereas personal tax rate increases are correlated with a smaller lagged budget surplus (or a larger lagged budget deficit).
} 
which the firm operates, as shown in equation (6). We see the original coefficients of interest $\beta_{C, C}$ and $\beta_{P, P}$ essentially unchanged from the baseline regression of column (2) in Table 4. As predicted, the coefficients on the average tax rate on the other states where the firm operates have opposite signs. So $\varphi_{C, C}$, the coefficient on $\left(\widetilde{\tau}_{C,-s} \times \operatorname{Corp}\right)$, has a point estimate of 0.016 and is statistically significant at the $1 \%$ level. Similarly, $\varphi_{P, P}$, the coefficient on $\left(\widetilde{\tau}_{P,-s} \times\right.$ PassThrough $)$, has a point estimate of 0.005 and is significant at the $5 \%$ level. The cross terms $\varphi_{P, C}$ and $\varphi_{C, P}$ are statistically and economically insignificant.

Changes in the tax rates of other states where the parent firm has establishments therefore have about half of the effect as the tax rates of the state of the establishment itself. So for example, if all other states in which a firm operates increase the corporate tax rate by 100 basis points and state $s$ maintains the level of its corporate tax rate, state $s$ sees an establishment inflow amounting to 0.016 establishments per firm. ${ }^{25}$ This inflow to state $s$ would then eliminate around half of the outflow from the other states, and is the basis of our conclusion that around half of the baseline effects are driven by reallocation of productive resources to other states where the treated firms have establishments. ${ }^{26}$

In Table 7 , we show analysis that is analogous to Table 4 but now we examine the intensive margin in terms of number of employees in specifications with establishment fixed effects. The level of observation is now the establishment-year, of which there are 27.6 million belonging to firms with more than 100 employees and active in more than one state. The results indicate an elasticity of $\mathrm{C}$ corporation employment of 0.4 with respect to the state corporate income tax rate, and an elasticity of pass-through business employment of 0.2 with respect to the personal income tax rate. In other words, a one percentage point change in the state corporate rate has an opposite effect on employment at existing establishments of $\mathrm{C}$ corporations by 0.4 percentage points. A one percentage point change in the state personal rate has an opposite effect on employment at existing establishments of pass-through entities by 0.2 percentage points. We

\footnotetext{
${ }^{25}$ As in the baseline specifications, moving to a Poisson regression reduces the magnitudes by $20-30 \%$.

${ }^{26}$ Firm-level specifications that "net out" the reallocation by aggregating the number of establishments at the firm level confirm this finding. In column (1) of Appendix Table A4, we aggregate the number of establishments at the firm level and regress $\log$ (establishments) on the firm-level analogs of the tax items-computed as (employeeweighted) averages across all states in which the company has establishments. As is shown, the coefficient of $\bar{\tau}_{C} \times \operatorname{CCorp}\left(\bar{\tau}_{P} \times\right.$ PassThrough) is -0.0015 (-0.0011), implying that a 100 basis point increase in the corporate (personal) income tax rate corresponds to a decrease in the number of establishments by $0.15 \%(0.11 \%)$. This is less than half the magnitude of the estimates in Table 4, consistent with our finding that reallocation across states offsets part of the baseline effect. Column (2) also reports estimates with respect to $\log$ (employees); columns (3)-(5) report estimates pertaining to the manufacturing sector.
} 
caution that since our sample is of firms that already have establishments in multiples states, the effects we measure are reflective of the responses of firms that are more cheaply able to shift factors of production across state borders than firms operating in only one state. As in the extensive margin analysis, the coefficients on the cross terms $\beta_{C, P}$ and $\beta_{P, C}$ are economically negligible and statistically insignificant. Also, as can be seen in column (3), we find that roughly half of the effect is offset by reallocation across states, similar to what we observed in Table 4 .

On the labor adjustment margin, we also find an impact of UI contribution requirements. An increase in the UI rate by 100 basis points will increase the log of the UI contribution by 0.14 . Since the coefficient in column (2) is -0.011 , this implies a 100 basis point increase in the UI tax rate would lead to a decrease in the number of establishments by $-0.011 \times 0.14=-0.15 \%$. The tax incentive index also enters with a statistically significant coefficient of 0.0009 . A one standard deviation change in this index by 6 points therefore has an effect on employment of $0.5 \%$ at existing establishments. Compared to Table 4, the tax incentives index seems to have a greater effect on employment within existing establishments than on the setting up of new establishments.

In Table 8, we perform similar robustness tests as in Table 5, but this time we examine the intensive margin of employment in existing establishments, as in Table 7 . The basic patterns are very similar as in the extensive margin analysis. Under region-by-year fixed effects, $\beta_{C, C}$ is around $26 \%$ larger than without, and $\beta_{P, P}$ is $11 \%$ weaker. With industry trends, both effects are $16-18 \%$ weaker. The results are robust to excluding a 5-year window around LFO changes and relying solely on the unpredicted component.

\section{B. Large Tax Changes and the Narrative Approach}

In this section we focus on large tax changes, which we define as increases or decreases in tax rates that are at least 100 basis points. The purpose of examining these large changes is to obtain a sample on which we can manageably conduct analysis of the reasons for the tax changes, and also so that we can obtain a clean setting without overlapping tax changes for difference-indifference analysis. We identify 56 such changes in the corporate tax rate and 105 such changes in the personal tax rate, for a total of 161 changes.

Table 9 shows a difference-in-difference analysis of the large tax changes for the extensive margin, as in equation (8). We construct four samples for this analysis, for each of four different types of tax changes: corporate tax cuts, corporate tax increases, personal tax cuts, and personal 
tax increases. To do this, we select all firm-state-year observations for the treated states three years before and three years after the major tax changes of each of the four types. Compared to coefficients from Table 4 ( $\beta_{C, C}=-0.031$ and $\left.\beta_{P, P}=-0.010\right)$, columns (1), (3), (5), and (7) show coefficients of $0.027,-0.014,0.018$, and -0.005 for the effects of corporate tax cuts, corporate tax increases, personal tax cuts, and personal tax increases respectively on establishment counts. The first three of these are significant at the $1 \%$ level, while the coefficient on the personal tax increases is not statistically significant at conventional levels. Columns (2), (4), (6), and (8) show the impulse response of the tax changes. Around half of the impact is observed in the year of the treatment, and the rest in the following year. The coefficients on Treatment $(+1)$ are 0.031 , $-0.017,0.028$, and -0.003 respectively, with the first three once again significant at $1 \%$ and the personal tax increase impact not statistically significant. Figure 5 shows this dynamic response graphically by plotting the coefficients from $t-2$ to $t+2$ for each of the four coefficients.

In Table 10, we then implement the narrative approach in this sample as discussed in Section II.D. In columns (1), (2), (4), and (6), we regress the number of establishments on the type of treatment: exogenous, endogenous, and unclassified. For categories where the changes classified as exogenous came through the 1981 and 1986 federal tax reforms, we break those out separately in columns (3), (5), and (7). In all of the specifications, there is no statistically or economically distinguishable difference among the coefficients on the different types of tax changes. For large corporate tax cuts, large corporate tax increases, and large personal tax cuts, the effects on establishment counts are uniformly of the predicted sign, of a similar magnitude to the difference-in-difference specification, and statistically significant.

Table 11 provides an analysis parallel to that in Table 9 but on the intensive margin, with $\log$ (employees) on the left hand side. In contrast to the extensive margin results, where we found statistically significant coefficients on all categories except large increases in the personal income tax, here we find statistically significant coefficients on all categories except large decreases in the personal income tax. Recall that in the full-sample intensive margin analysis, we found an elasticity of $\mathrm{C}$ corporation employment of 0.4 with respect to the state corporate income tax rate, and an elasticity of pass-through business employment of 0.2 with respect to the personal income tax rate. As in Table 9, the coefficients on the responses to treatment most closely match these one year after treatment, that is in the coefficients on Treatment $(+1)$. Figure 6 shows this dynamic response graphically by plotting the coefficients from $t-2$ to $t+2$ for each of the four 
coefficients.

In Table 12 we conduct the textual analysis on the intensive margin with $\log$ (employees) as the dependent variable. Once again, in all of the specifications, there is no statistically or economically distinguishable difference among the coefficients on the different types of tax changes. For large corporate tax cuts, large corporate tax increases, and large personal tax increases, the effects on employment are uniformly of the predicted sign, of a similar magnitude to the difference-in-difference specification, and statistically significant.

\section{Apportionment Factors and Throwback Rules}

In Table 13 we present the results of the apportionment factor analysis described in Section II.B. The first column incorporates the fact that if a state has a high sales apportionment factor, then changes in the state tax rate would be expected to have a smaller effect on the firm's decision to relocate plants and employees than if the state has a higher weighting on payroll and property. Indeed, relocating plants and employees has only a limited effect on the firm's tax burden if that tax burden is determined largely by the location where the goods are sold, not the location where the production is located. In the first column, the state tax rate $\tau_{C}$ is therefore interacted

with $\left(1-\alpha_{\text {sales }}^{i}\right)$, whereby we note once again that we do not actually observe the location to which the firm's output is sold.

The baseline effect on a firm's establishments in a state with a $100 \%$ sales apportionment factor is measured by the first coefficient -0.013 , whereas the effect in a state with a $33 \%$ sales apportionment factor (the minimum) would be $-0.013-0.66 \times 0.041=-0.040$. This compares to the main coefficient in Table 4 of $\beta_{C, C}=-0.031$, which at the mean represented an effect of $0.44 \%$ in the number of establishments. The first coefficient in Table 13 therefore implies that the point estimates of the effect of an increase in the tax rate on the number of establishments would range from $0.18 \%$ to $0.57 \%$ depending on the size of the apportionment factor. If firms generally tend to sell out of the state, then this difference is explained by the differential incentives facing firms in high versus low sales apportionment states. A similar spread is estimated for passthrough entities. Column (3) shows similar results on the intensive margin of employment, with elasticities ranging from $-0.15 \%$ when $\alpha_{\text {sales }}^{i}$ is $100 \%$, to $-0.47 \%$ when $\alpha_{\text {sales }}^{i}$ is $33 \%$.

In columns (2) and (4), the state tax rate $\tau_{C}$ is interacted with $\left(1-\alpha_{\text {sales }}^{i}\left(1-I_{\text {throwback }}\right)\right)$. If firms primarily sell not only out of state but also to states with no corporate tax or where they have no nexus, then throwback rules dampen the effect discussed in the previous para- 
graph. That is, throwback rules limit the extent to which sales apportionment factors reduce the incentives for firms to relocate establishments and employees. These results mirror those in columns (1) and (3) albeit with somewhat smaller magnitudes, perhaps because the assumptions needed about the location of sales do not always hold in the data.

In Table 14 we investigate the effects of apportionment factors and throwback rules using the second approach, where we track all states in which manufacturing firms have nexus, and assign precise values of property shares and payroll shares in the calculation of apportionmentadjusted tax rates. The regression analysis in this case measures the firm's response to a change in the actual tax claim on a dollar of total (national) corporate profit by one percentage point. The data requirements of this analysis require us to focus only on the manufacturing subsample. However, the availability of the capital stock variable in this subsample allows us to study capital allocation decisions of firms in response to tax changes.

Column (1) of Table 14 shows the coefficients in an estimation of equation (7) with $\log$ (employees) as the dependent variable, but only including the 854,700 establishment-level observations that are in manufacturing, using statutory (not apportionment-adjusted) tax rates. On the intensive margin within establishments over time, we find a coefficient of -0.0033 , smaller than the full-sample coefficient of -0.0041 from Table 7 , consistent with a smaller elasticity. However, when we use effective state tax rates that account for apportionment factors and the firm's share of capital and labor in each state (as in equation (1)), the coefficient returns to -0.0042 as shown in Column 3, very close to the full-sample estimate using statutory rates. This estimate is again consistent with an elasticity of labor with respect to the state tax rate of around 0.4. Columns (3) and (4) show a somewhat lower point estimate of the elasticity of capital with respect to the apportionment-factor adjusted effective tax rate. The capital elasticity is measured at 0.27 . Columns (5) and (6) additionally implement the throwback rule as shown in equation (2), using an effective tax rate that adjusts for both apportionment factors and throwback rules, assuming that all the shipments of the plant go to states where the firm has no nexus or states where there is no corporate tax. The results here are a labor elasticity of 0.44 and a capital elasticity of 0.29 .

Note that in these regressions we do not find statistically significant coefficients on the pass-through entity response to the personal tax rate. However, this may to some extent reflect the relatively small number of manufacturing firms operating in multiple states as pass-through 
entities with more than 100 employees. As shown in Table 1, there are only 11,100 firms in the US that fit this description, compared to 93,300 manufacturing C-Corps.

\section{Heterogeneous Effects Across Industries}

Our final set of results examines heterogeneous treatment effects across different industries. In the top graph of Figure 7, we plot the coefficients on $\left(\tau_{C} \times\right.$ CCorp $)$ and $\left(\tau_{P} \times\right.$ PassThrough $)$ from a variant of the baseline extensive margin specification in which the tax variables are also interacted with industry dummies for eight broad industry categories. The industry sectors are agriculture and mining (SIC 1-14), construction (15-19), manufacturing (20-39), utilities (4049), wholesale and retail trade (50-59), financials (60-69), services (70-89), and other (90-99). ${ }^{27}$ We see that the industries most responsive on the extensive margin (actual opening and closing of establishments in response to taxation) are retail/wholesale, services, and financials, while perhaps unsurprisingly agriculture and mining are the least sensitive. In retail/wholesale, a one percentage point change in the corporate rate affects the number of establishments in the state per $\mathrm{C}$ Corporation firm by over $0.5 \%$. The effects on manufacturing are in the middle. The ordering of pass-through coefficients is similar, and the magnitudes are somewhat smaller as in the full sample.

The bottom graph of Figure 7 shows an analogous investigation for the intensive margin. The ordering of industries by the strength of response is quite similar to the ordering on the extensive margin in the top graph. In retail/wholesale and services, we find elasticities of employment with respect to the state tax rate of over $1 \%$. The ordering of pass-through coefficients is again similar, and the magnitudes are again somewhat smaller as in the full sample.

\section{Conclusions}

In this paper we have estimated economic responses to state-level business taxation by multistate firms on both the extensive and intensive margins. We find evidence consistent with substantial responses of these firms to state tax rates for the relevant tax rules. Corporate entities reduce the number of establishments per state and the number of employees and amount of capital per plant when state tax rates increase. Pass-through entities respond similarly to

\footnotetext{
${ }^{27}$ This classification is based on SIC divisions, as opposed to SIC major groups (i.e., two-digit SIC industries).
} 
changes in state-level personal tax rates, although in somewhat smaller magnitude. Our specifications suggest that around half of these responses are due to reallocation of business activity to lower-tax states.

We have implemented a number of techniques and robustness tests to validate that the results are not due to spurious correlations between tax rate changes and state business activity. Most importantly, the specifications implicitly use pass-through entities as a control sample around corporate tax changes and corporate entities as a control sample around personal tax changes. The lack of cross-correlations supports the identifying assumption in these regressions that there are not state-level trends in general business activity around changes in tax policy. In addition the results are robust to using innovations in tax policy relative to a baseline regression, to controlling for regional or industry trends, and to excluding firms that change their organizational form. Responses begin upon implementation of the tax policy, and we find no evidence of trends prior to the treatment.

These findings leave a number of important areas open for further research, of which we highlight three here. First, we emphasize that we analyze only firms that already have establishments in multiple states. It seems important also to analyze the behavior of single-state and smaller firms with respect to changes in state-level tax policy. It stands to reason that these would be less elastic in their decision to reallocate business activity, but perhaps not in their overall response to tax policy. Second, the differential taxation of $\mathrm{C}$ corporations and pass-through entities could distort competition by giving an advantage to one type of firm or another. Investigating the impact of state taxation on the product market would shed light on this phenomenon. Third, we have controlled for non-income-based state and local taxes, such as unemployment insurance, sales taxes and property taxes, but more work remains to be done on the impact of changes in these taxes and their structure on business activity. 


\section{Appendix: Calculation of Capital Stock}

Following Lichtenberg (1992), capital stock is computed using the perpetual inventory method. This method requires an initial value of real capital stock. For each plant, we select the earliest available book value of capital in the CMF/ASM. To account for depreciation, we multiply this value by the 2-digit SIC adjustment factor from the Bureau of Economic Analysis (BEA). This adjustment factor is the ratio of industry net capital stock in current dollars to industry gross capital stock in historical dollars. The adjusted book value of capital is then divided by the 4-digit SIC investment deflator from the NBER-CES Manufacturing Industry Database. If the earliest available book value of capital corresponds to the year in which the plant was "born" (as identified by the birth flag in the LBD), no adjustment for depreciation is needed. In this

case, the book value is simply divided by the 4-digit SIC investment deflator. The initial value of real capital stock is then written forward using the recursive perpetual inventory formula

$$
K_{i t}=\left(1-\delta_{i t}\right) \times K_{i t-1}+I_{i t},
$$

where $i$ indexes plants, $t$ indexes years, $K$ is the value of real capital stock, $\delta$ is the 2-digit SIC depreciation rate from the BEA, and $I$ is capital expenditures divided by the 4-digit SIC investment deflator. Until the 1997 Census, all necessary variables are available separately for buildings and machinery. Accordingly, we calculate the capital stock for each asset category, and add them together to obtain the final measure of capital stock. As of 1997, only aggregate capital stock variables are available. 


\section{References}

Aronson, Richard, and John L. Hilley, 1986, Financing State and Local Governments, Washington, DC: The Brookings Institution.

Bania, Neil, Jo Anna Gray, and Joe A. Stone, 2007, "Growth, Taxes, and Government Expenditures: Growth Hills for U.S. States," National Tax Journal 60(2), 193-204.

Bartik, Timothy J., 1985, "Business Location Decisions in the United States: Estimates of the Effects of Unionization, Taxes, and Other Characteristics of States," Journal of Business and Economic Statistics 3(1), 14-22.

Bartik, Timothy J., 1991, Who Benefits from State and Local Economic Development Policies? Kalamazoo, MI: Upjohn Institute for Employment Research.

Brülhart, Marius, Maio Jametti, and Kurt Schmidheiny, 2012, "Do Agglomeration Economies Reduce the Sensitivity of Firm Location to Tax Differentials?" The Economic Journal 122(563), 1069-1093.

Carlton, Dennis W., 1979. "Why Do Firms Locate Where They Do?: An Econometric Model," in Interregional Movements and Regional Growth, Wheaton, William, ed., Washington, DC: The Urban Institute.

Carlton, Dennis W., 1983, "The Location and Employment Choices of New Firms: An Econometric Model with Discrete and Continuous Endogenous Variables," Review of Economic and Statistics 65(3), 440-449.

Congressional Budget Office, 2012, "Taxing Business through the Individual Income Tax," Publication Number 4298.

Coughlin, Cletus C., Joseph V. Terza, and Vachira Arromdee, 1991, "State Characteristics and the Location of Foreign Direct Investment within the United States," Review of Economics and Statistics 68(4), 675-683.

Davis, Steven J., and John Haltiwanger, 1992, "Gross Job Creation, Gross Job Destruction, and Employment Reallocation," Quarterly Journal of Economics 107(3), 819-863. 
Fox, William F., 1981, "Fiscal Differentials and Industrial Location: Some Empirical Evidence," Urban Studies 18(1), 105-111.

Fox, William F., 1986, "Tax Structure and the Location of Economic Activity Along State Borders," National Tax Journal 39(4), 387-401.

Gabe, Todd M., and Kathleen P. Bell, 2004, "Tradeoffs Between Local Taxes and Government Spending as Determinants of Business Location," Journal of Regional Science 44(1), 21-41.

Gale, William G., Aaron Krupkin, and Kim Rueben, 2015, "The Relationship between Taxes and Growth at the State Level: New Evidence," Tax Policy Center Working Paper.

Goolsbee, Austan, 1998, "Taxes, Organizational Form and the Deadweight Loss of the Corporate Income Tax," Journal of Public Economics 69(1), 143-152.

Goolsbee, Austan, and Edward L. Maydew, 2000, "Coveting Thy Neighbor's Manufacturing: The Dilemma of State Income Apportionment," Journal of Public Economics 75(1), 125143.

Goolsbee, Austan, 2004, "The Impact of the Corporate Income Tax: Evidence From State Organizational Form Data," Journal of Public Economics 88(11), 2283-2299.

Gordon, Roger, and Jeffrey K. MacKie-Mason, 1990, "Effects of the Tax Reform Act of 1986 on Corporate Financial Policy and Organizational Form," in Do Taxes Matter, Slemrod, Joel, ed., Cambridge, MA: MIT Press.

Gordon, Roger, and Jeffrey K. MacKie-Mason, 1994, "Tax Distortions to the Choice of Organizational Form," Journal of Public Economics 55(2), 279-306.

Gordon, Roger, and Jeffrey K. MacKie-Mason, 1997, "How much do Taxes Discourage Incorporation?" Journal of Finance 52(2), 477-505.

Gordon, Roger, and John D. Wilson, 1986, "An Examination of Multijurisdictional Corporate Income Taxation under Formula Apportionment," Econometrica 54(6), 1357-1373.

Gravelle, Jane G., 1994, The Economic Effects of Taxing Capital Income, Cambridge: MIT Press. 
Gravelle, Jane G., and Lawrence Kotlikoff, 1988, "Does the Harberger Model Greatly Understate the Excess Burden of the Corporate Income Tax?" NBER Working Paper \#2742.

Gravelle, Jane G., and Lawrence Kotlikoff, 1989, "The Incidence and Efficiency Costs of Corporate Taxation When Corporate and Noncorporate Firms Produce the Same Good," Journal of Political Economy 97(4), 749-780.

Gravelle, Jane G., and Lawrence Kotlikoff, 1993, "Corporate Tax Incidence and Inefficiency when Corporate and Noncorporate Goods are Close Substitutes," Economic Inquiry 31(4), 501-516.

Grieson, Ronald E., 1980, "Theoretical and Empirical Analysis of the Effects of the Philadelphia Income Tax," Journal of Urban Economics 8(1), 123-137.

Grieson, Ronald E., William Hamovitch, Albert M. Levenson, and Richard D. Morgenstern, 1977, "The Effect of Business Taxation on the Location of Industry," Journal of Urban Economics 4(1), 170-185.

Gruber, Jonathan, and Joshua Rauh, 2007, "How Elastic is the Corporate Income Tax Base?" in Taking Corporate Income in the 21st Century, Auerbach, Alan, James R. Hines, and Joel Slemrod, eds., Cambridge, MA: Cambridge University Press.

Guimaraes, Paulo, Octavio Figueiredo, and Douglas Woodward, 2003, “A Tractable Approach to the Firm Location Decision Problem," Review of Economics and Statistics 85(1), 201204.

Guimaraes, Paulo, Octavio Figueiredo, and Douglas Woodward, 2004, "Industrial Location Modeling: Extending the Random Utility Framework," Journal of Regional Science 44(1), $1-20$.

Gupta, Sanjay, and Lillian Mills, 2002, "Corporate Multistate Tax Planning: Benefits of Multiple Jurisdictions," Journal of Accounting and Economics 33(1): 117-139.

Harberger, Arnold, 1962, "The Incidence of the Corporate Income Tax," Journal of Political Economy 70(3), 215-240.

Hausman, Jerry, Bronwyn Hall, and Zvi Griliches, 1984, "Econometric Models for Count Data with an Application to the Patents-R\&D Relationship," Econometrica 52(4), 909-938. 
Helms, L. Jay, 1985, "The Effect of State and Local Taxes on Economic Growth: A Time Series-Cross Section Approach," The Review of Economics and Statistics 67(4), 574-582.

Hennessy, Christopher, and Ilya Strebulaev, 2015, "Natural Experiment Policy Evaluation: A Critique," NBER Working Paper \#20978.

Hines, James R., 1996, “Altered States: Taxes and the Location of Foreign Direct Investment in America," American Economic Review 86(5), 1076-1094.

Holcombe, Randall G., and Donald L. Lacombe, 2004, "The Effect of State Income Taxation on Per Capita Income Growth," Public Finance Review 32(3), 292-312.

Holmes, Thomas J., 1998, "The Effect of State Policies on the Location of Manufacturing: Evidence from State Borders," Journal of Political Economy 106 (4), 667-705.

Jarmin, Ron S., and Javier Miranda, 2003, "The Longitudinal Business Database," CES Working Paper 02-17.

Klassen, Kenneth J., and Douglas Shackelford, 1998, "State and Provincial Corporate Tax Planning: Income, Sales, Assets, and Compensation Management," Journal of Accounting and Economics 25(3), 385-406.

Ladd, Helen F., 1993, "State Responses to the TRA86 Revenue Windfalls: A New Test of the Flypaper Effect," Journal of Policy Analysis and Management 12(1), 82-103.

Lichtenberg, Frank R., 1992, Corporate Takeovers and Productivity, Cambridge, MA: MIT Press.

Ljungqvist, Alexander, and Michael Smolyansky, 2014, "To Cut or Not to Cut? On the Impact of Corporate Taxes on Employment and Income," NBER Working Paper \#20753.

Lucas, Robert, 1976, "Econometric Policy Evaluation: A Critique," in The Phillips Curve and Labor Markets, Brunner, Karl, and Allan H. Meltzer, eds., Carnegie-Rochester Conference Series on Public Policy 1(1), 19-46.

McLure, Charles, 1980, "The State Corporate Income Tax: Lambs in Wolves' Clothing," in The Economics of Taxation, Aaron, Henry J., and Michael J. Boskin, eds., Washington, DC: The Brookings Institution. 
McLure, Charles E., 1981, "The Elusive Incidence of the Corporate Income Tax: The State Case," Public Finance Quarterly 9(4), 395-413.

Mertens, Karel, and Morten O. Ravn, 2013, "A Reconciliation of SVAR and Narrative Estimates of Tax Multipliers," Journal of Monetary Economics, forthcoming.

Mofidi, Alaeddin, and Joe A. Stone, 1990, "Do State and Local Taxes Affect Economic Growth?" Review of Economic Statistics 72(4), 686-691.

Newman, Robert J., 1983, "Industry Migration and Growth in the South," Review of Economics and Statistics 65(1), 76-86.

Papke, Leslie, 1987, "Subnational Taxation and Capital Mobility: Estimates of Tax-Price Elasticities," National Tax Journal 40(2), 191-203.

Papke, Leslie, 1991, "Interstate Business Tax Differentials and New Firm Location: Evidence from Panel Data," Journal of Public Economics 45(1), 47-68.

Rathelot, Roland, and Patrick Sillard, 2008, "The Importance of Local Corporate Taxes in Business Location Decisions: Evidence from French Micro Data," The Economic Journal 118(527), 499-514.

Reed, W. Robert, 2008, "The Robust Relationship between Taxes and U.S. State Income Growth," National Tax Journal 61(1): 57-80.

Romer, Christina D., and David H. Romer, 2010, "The Macroeconomic Effects of Tax Changes: Estimates Based on a New Measure of Fiscal Shocks," American Economic Review 100(3), 763-801.

Serrato, Juan Carlos, and Owen Zidar, 2014, "Who Benefits from State Corporate Tax Cuts? A Local Labor Markets Approach with Heterogeneous Firms," University of Chicago Working Paper.

Shoven, John B., 1976, "The Incidence and Efficiency Effects of Taxes on Income from Capital," Journal of Political Economy 84(6), 1261-1284.

Wasylenko, Michael, and Therese McGuire, 1985, "Jobs and Taxes: The Effect of Business Climate on States' Employment Growth Rates," National Tax Journal 38(4): 497-511. 
Wasylenko, Michael, 1991, "Empirical Evidence on Interregional Business Location Decisions and the Role of Fiscal Incentives in Economic Development," in Industry Location and Public Policy, Henry W. Herzog, Jr. and Alan M. Schlottmann, eds., Knoxville, TN: Univ. Tennessee Press. 


\section{Figure 1. Legal Forms of Organization over Time}

This figure plots the percentage of companies whose legal form of organization is C-corporation, S-corporation, and partnership or sole proprietorship. The sample includes all multi-unit companies in the Longitudinal Business Database (LBD) with at least 100 employees and establishments in at least two states. The sample period is from 1977 until 2011.

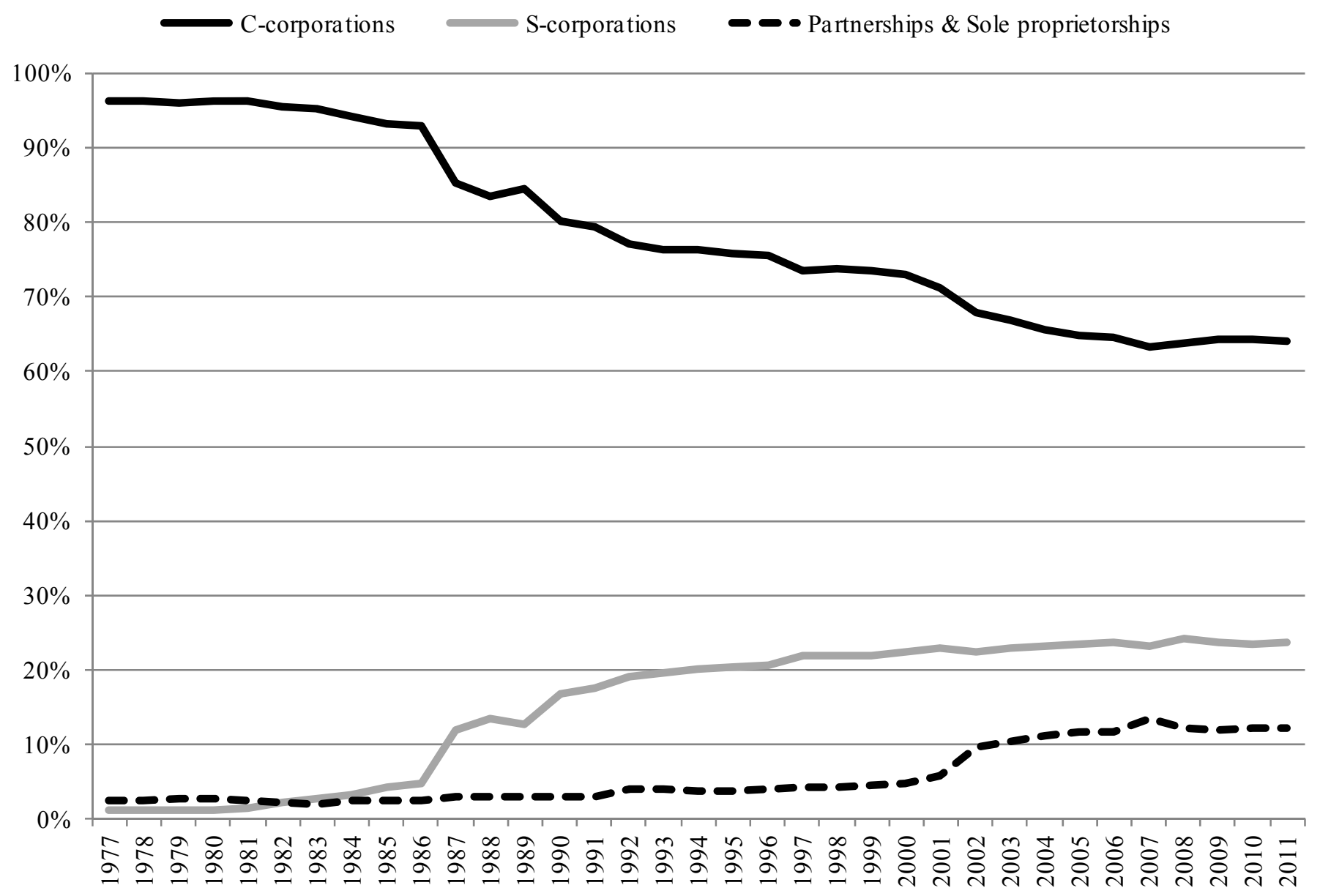




\section{Figure 2. Corporate and Personal Income Tax Rates over Time}

This figure plots the evolution of the mean and quartiles of the corporate income tax rate $\left(\tau_{\mathrm{c}}\right)$ and personal income tax rate $\left(\tau_{\mathrm{p}}\right)$, respectively, across all states from 1977 to 2011 .

\section{Panel (A): Corporate Income Tax Rate}

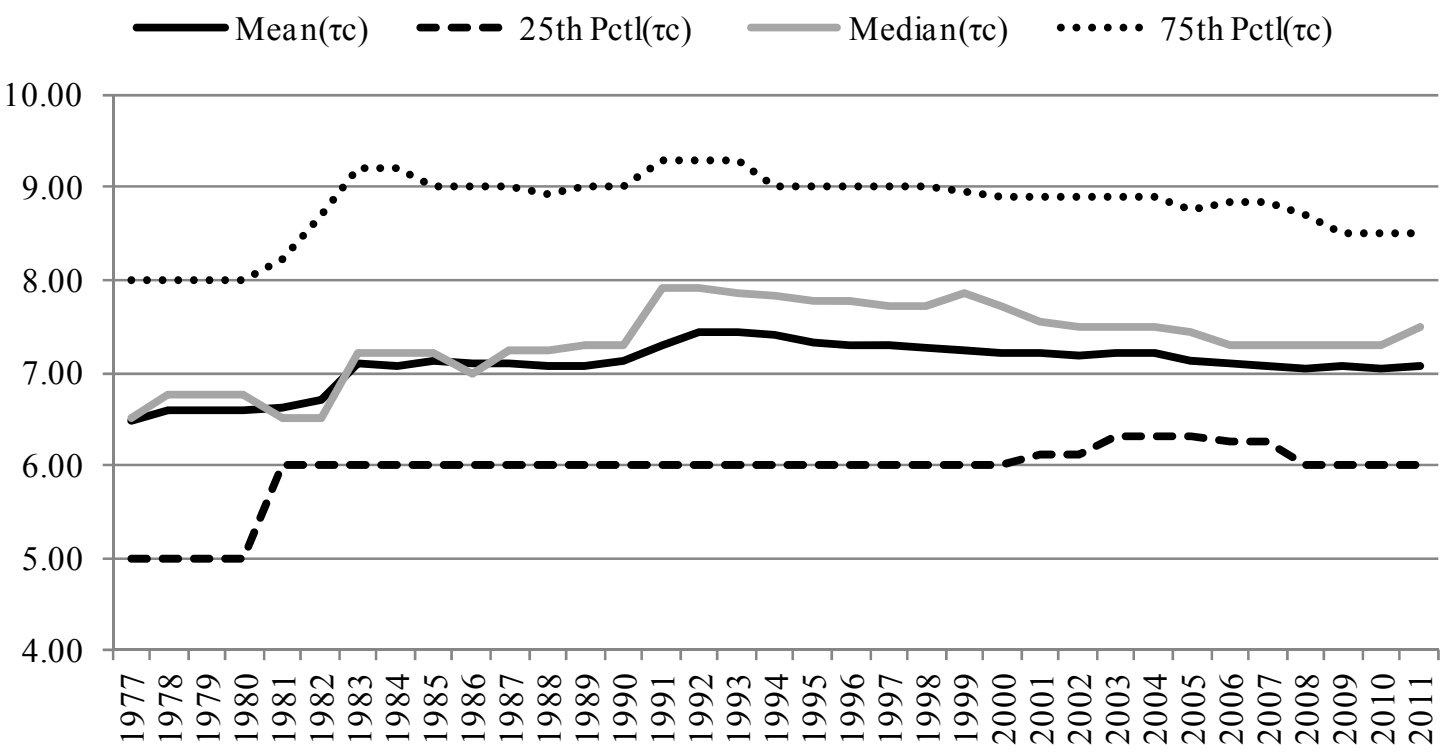

Panel (B): Personal Income Tax Rate

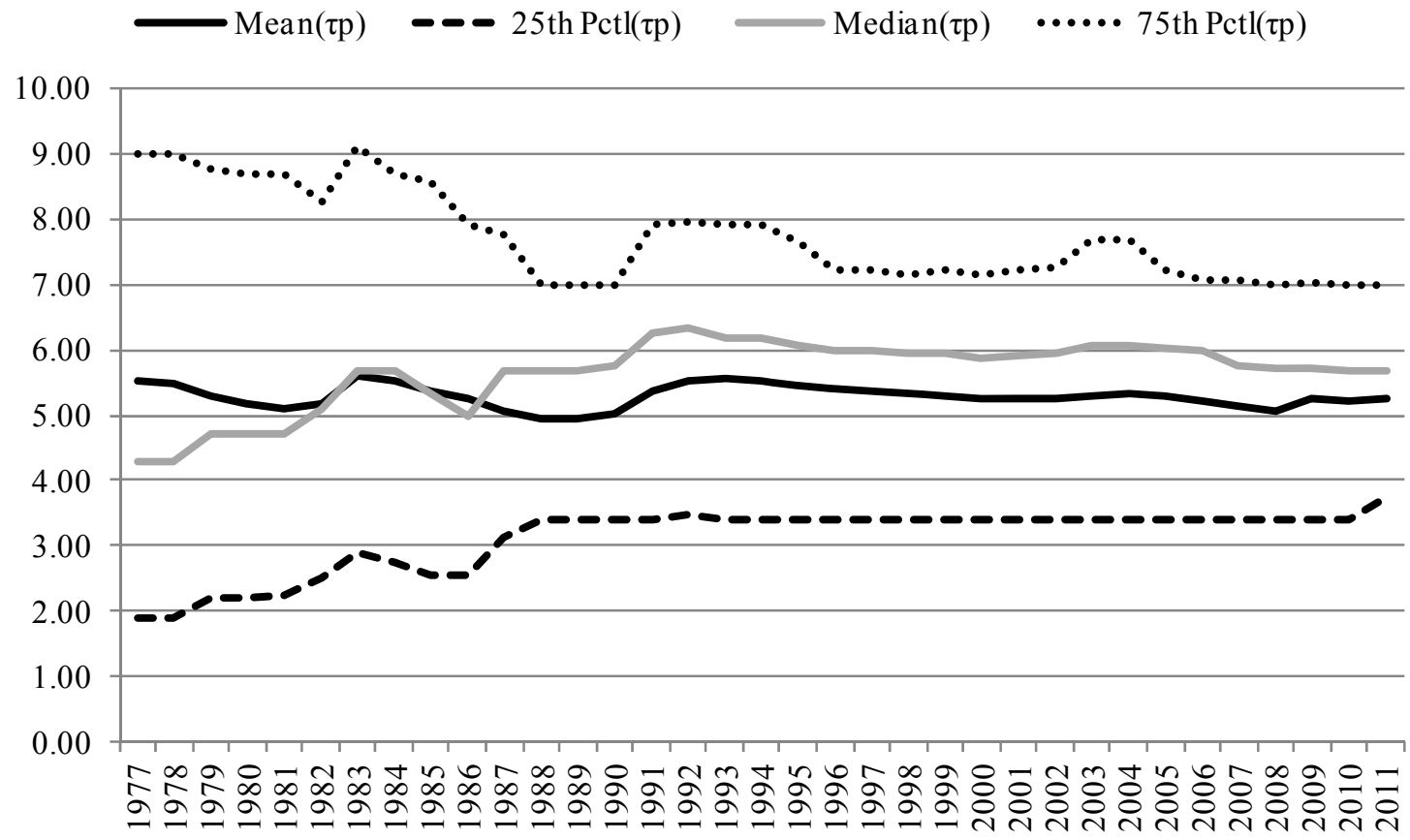




\section{Figure 3. Changes in Corporate and Personal Income Tax Rates over Time}

This figure plots the number of changes in the corporate income tax rate $\left(\tau_{c}\right)$ and personal income tax rate $\left(\tau_{\mathrm{p}}\right)$, respectively, across all states from 1977 to 2011.

Panel (A): Changes in Corporate Income Tax Rate

Number of increases in $\tau \mathrm{c} \quad$ Number of decreases in $\tau \mathrm{c}$

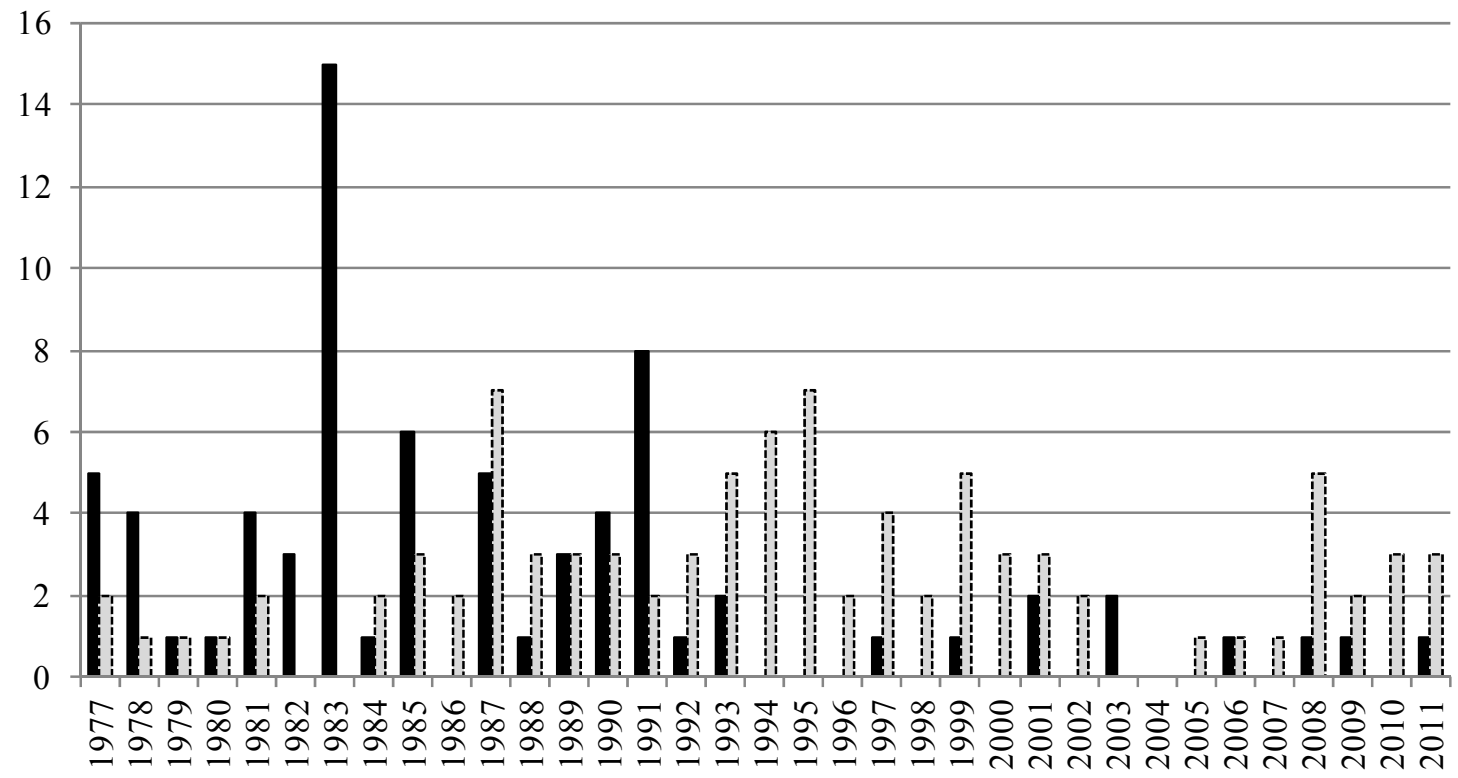

Panel (B): Changes in Personal Income Tax Rate

Number of increases in $\tau p \quad$ Number of decreases in $\tau p$

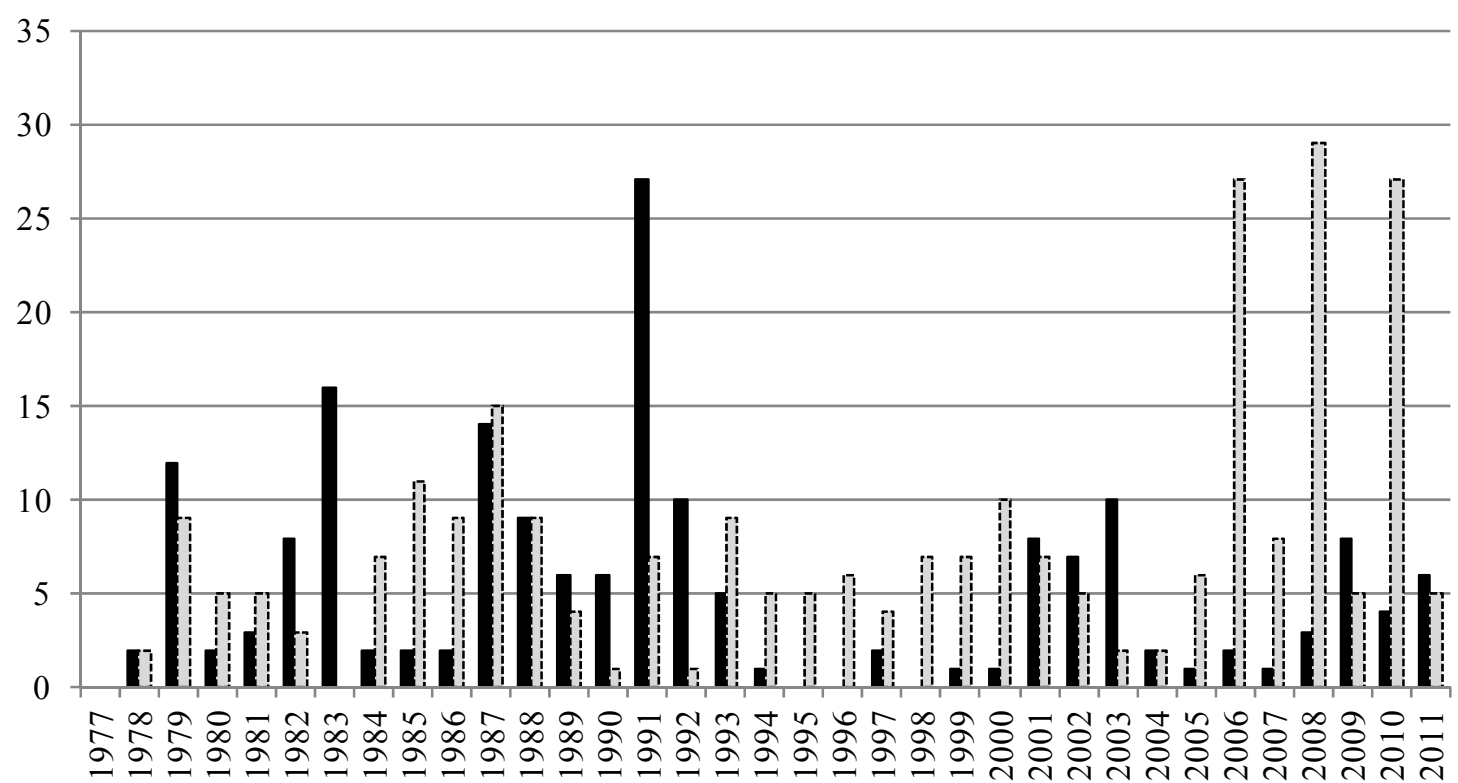




\section{Figure 4. Scatter Plots of Corporate and Personal Income Tax Rates}

Panel (A) provides a scatter plot of the personal income tax rate (vertical axis) and corporate income tax rate (horizontal axis) across all state-year observations from 1977 to 2011. Panel (B) provides a scatter plot of the yearto-year changes (first differences) in personal and corporate income tax rates.

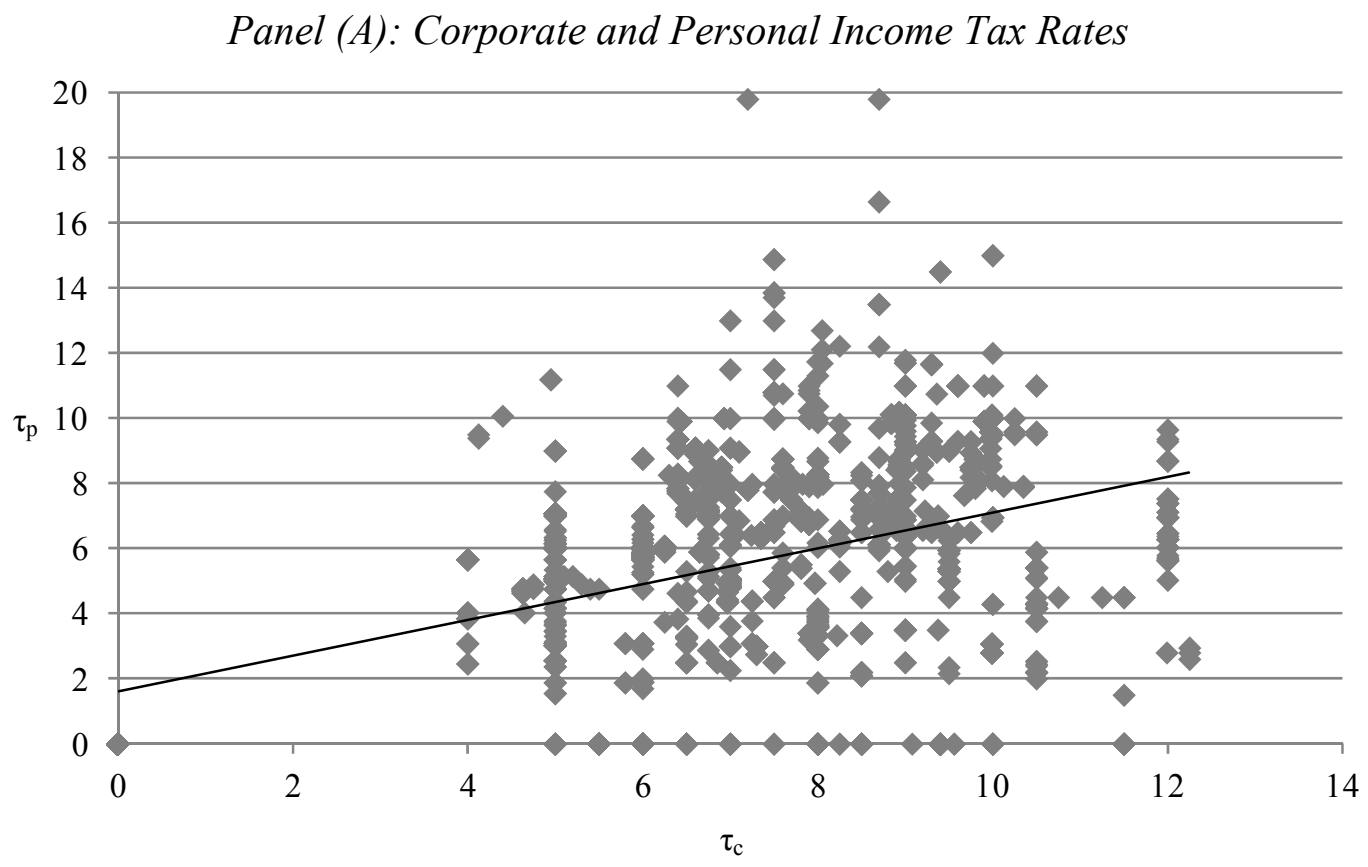

Panel (B): Changes in Corporate and Personal Income Tax Rates

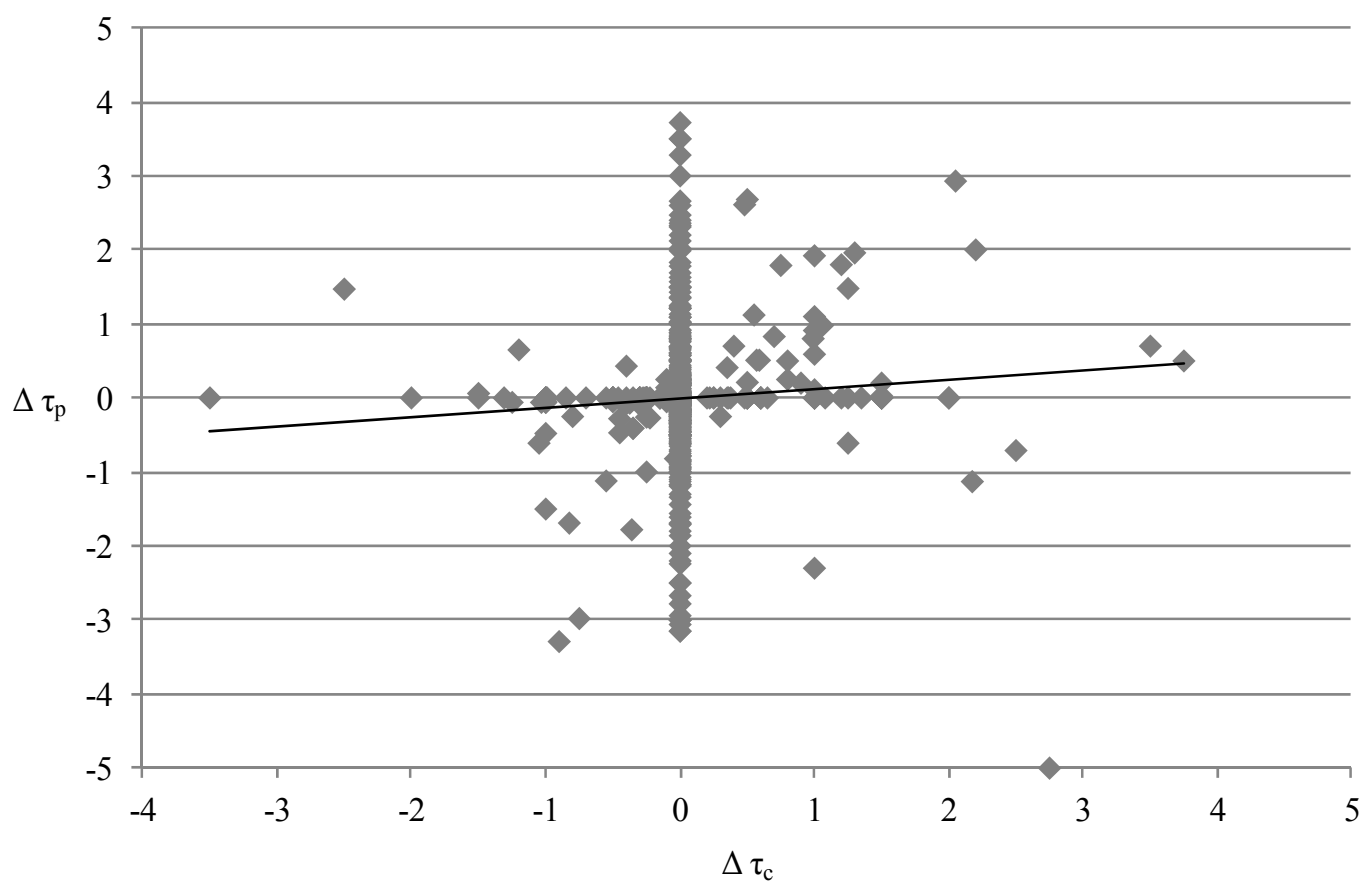




\section{Figure 5. Extensive Margin: Dynamic Effect of Large Tax Changes}

This figure plots the coefficients (and 95\% confidence intervals) corresponding to the dynamic analysis provided in Table 9 . See the legend of Table 9 for details.

Panel (A): Large cuts in corporate income tax rate

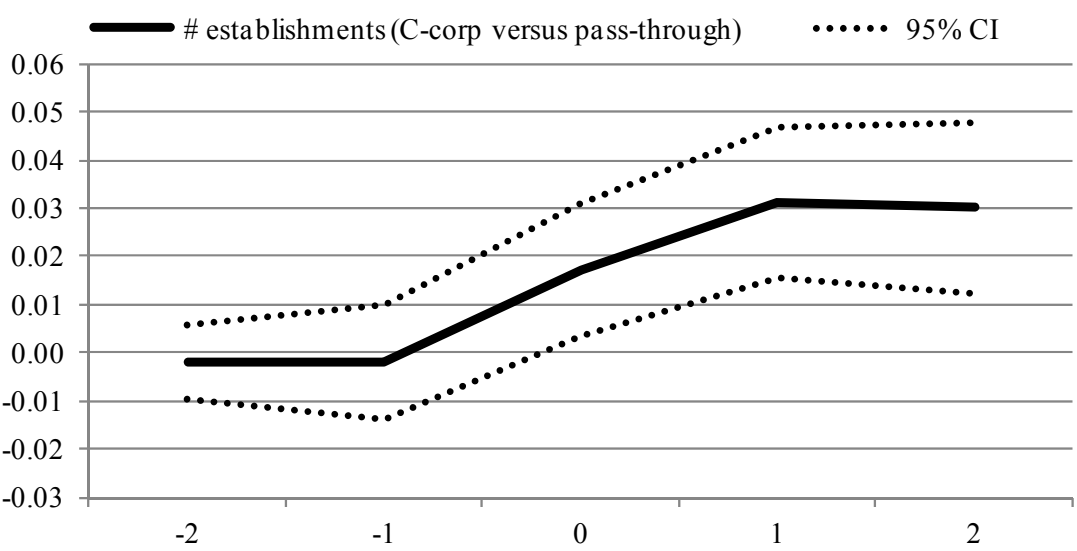

Panel (C): Large cuts in personal income tax rate

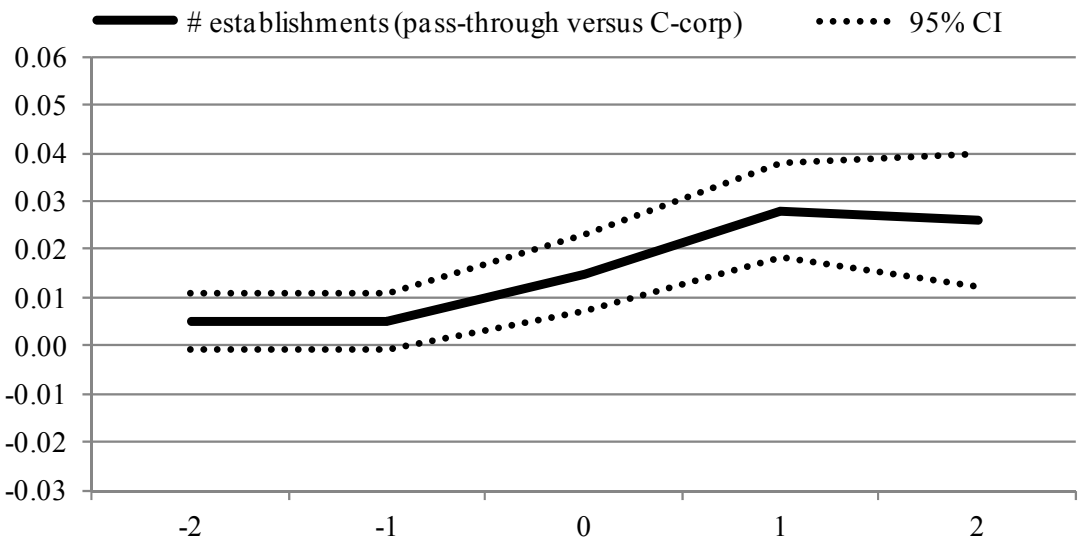

Panel (B): Large increases in corporate income tax rate

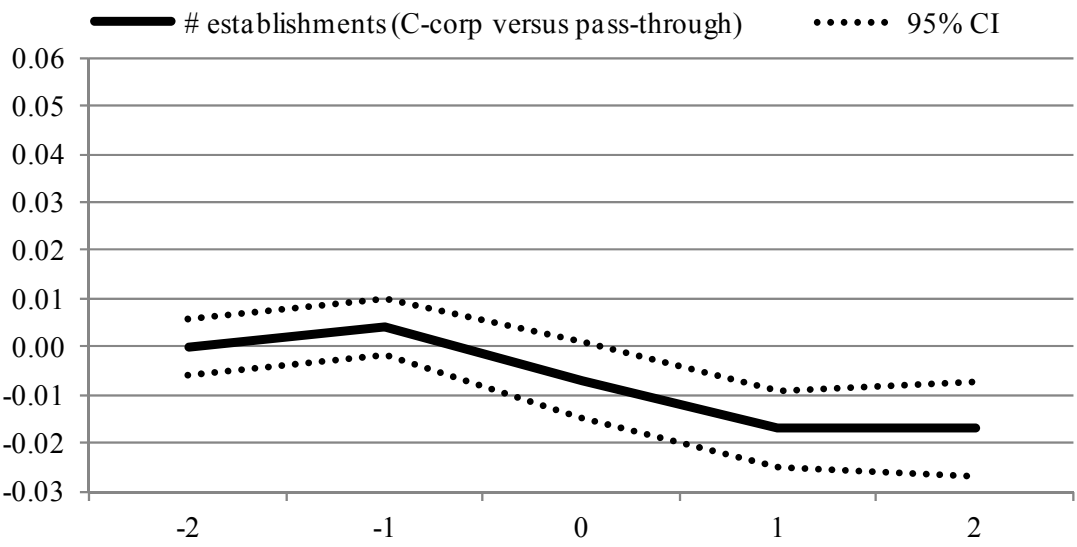

Panel (D): Large increases in personal income tax rate

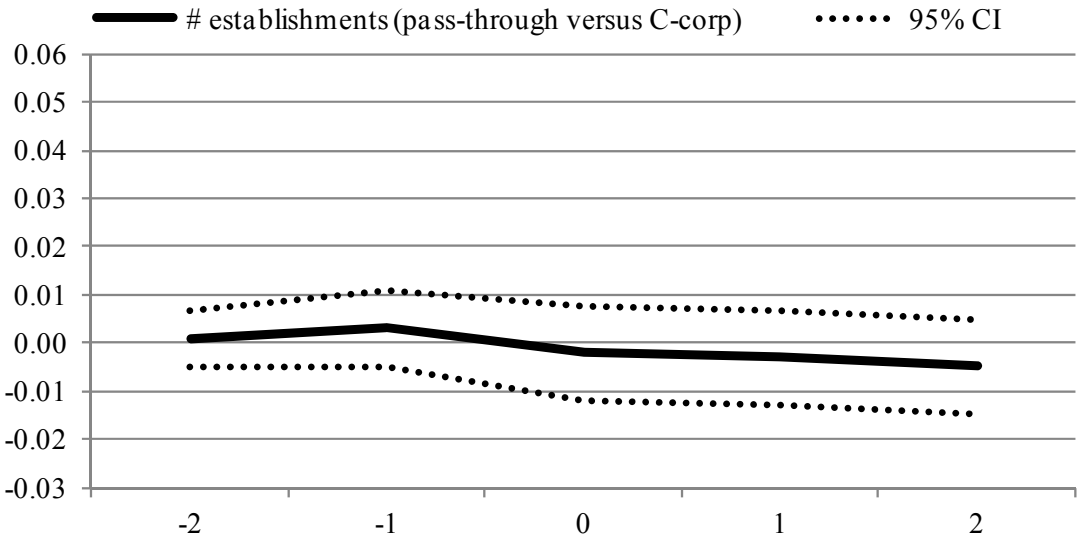




\section{Figure 6. Intensive Margin: Dynamic Effect of Large Tax Changes}

This figure plots the coefficients (and 95\% confidence intervals) corresponding to the dynamic analysis in Table 11. See the legend of Table 11 for details.

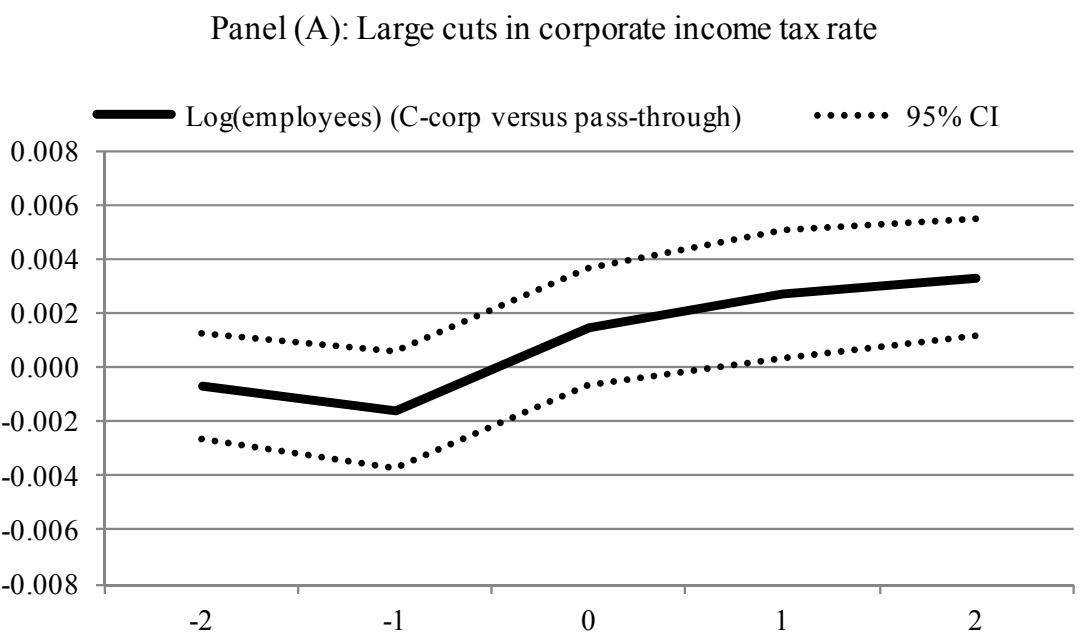

Panel (C): Large cuts in personal income tax rate

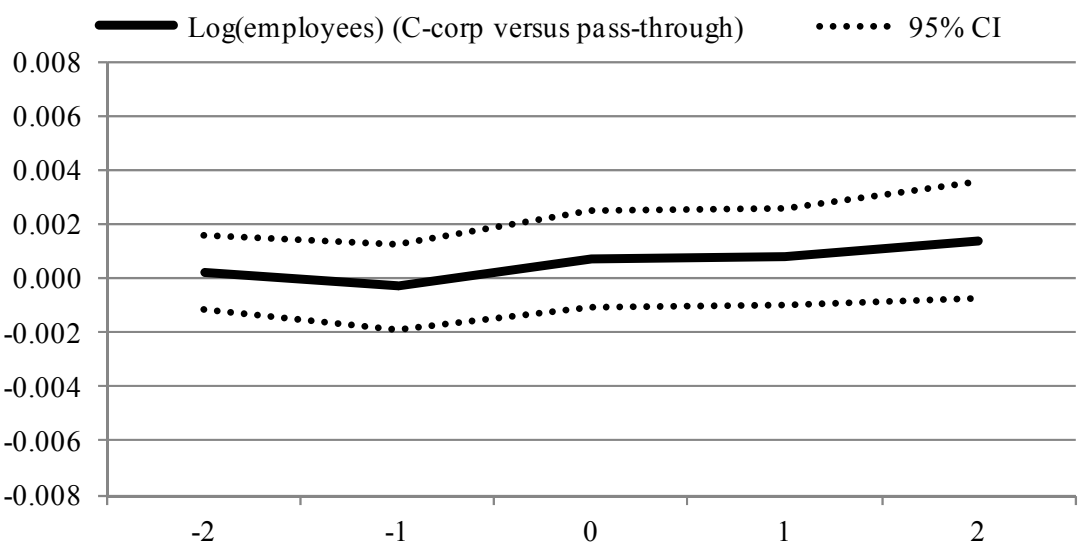

Panel (B): Large increases in corporate income tax rate

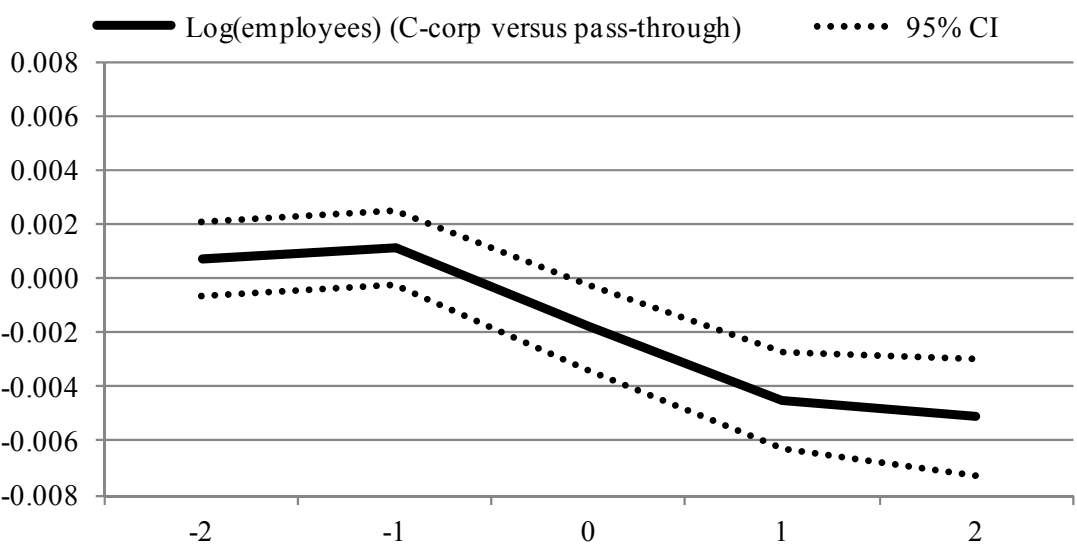

Panel(D): Large increases in personal income tax rate

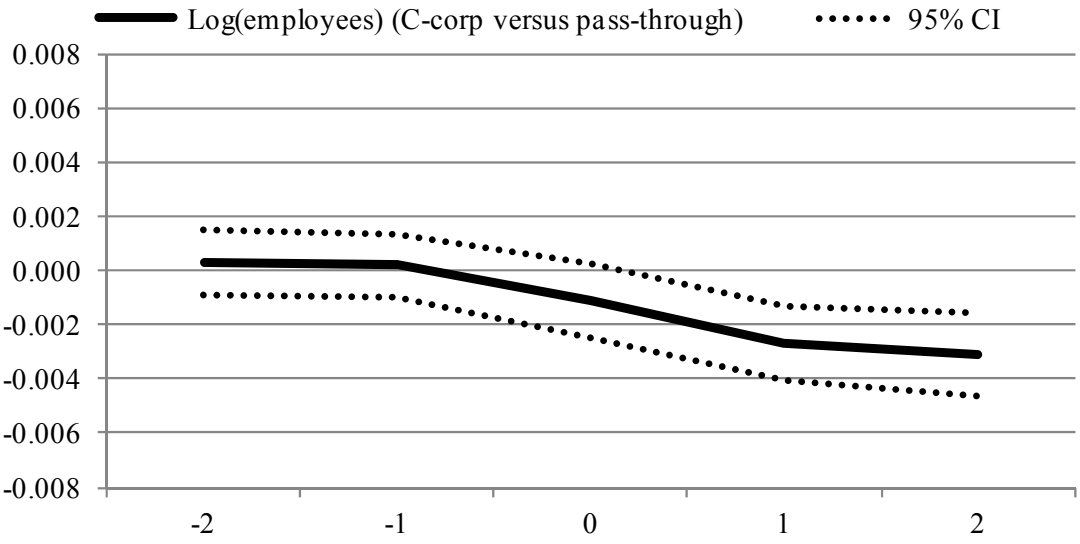


Figure 7. Industry Sectors

Panel (A) plots the coefficients $\beta_{C, C}\left(\tau_{\mathrm{c}} \times \mathrm{C}\right.$-Corp) and $\beta_{P, P}\left(\tau_{\mathrm{p}} \times\right.$ Pass-through) for eight major industry groupings. To derive these coefficients, we run a variant of the specification in column (2) of Table 4 , in which $\tau_{\mathrm{c}}$ and $\tau_{\mathrm{p}}$ are interacted with eight industry sector dummies. The industry sectors are agriculture and mining (SIC 1-14), construction (15-19), manufacturing (20-39), utilities (40-49), wholesale and retail trade (50-59), financials (60-69), services (70-89), and other (90-99). Panel (B) plots similar coefficients, but with respect to the specification in column (2) of Table 7.

\section{Panel (A): Extensive Margin}

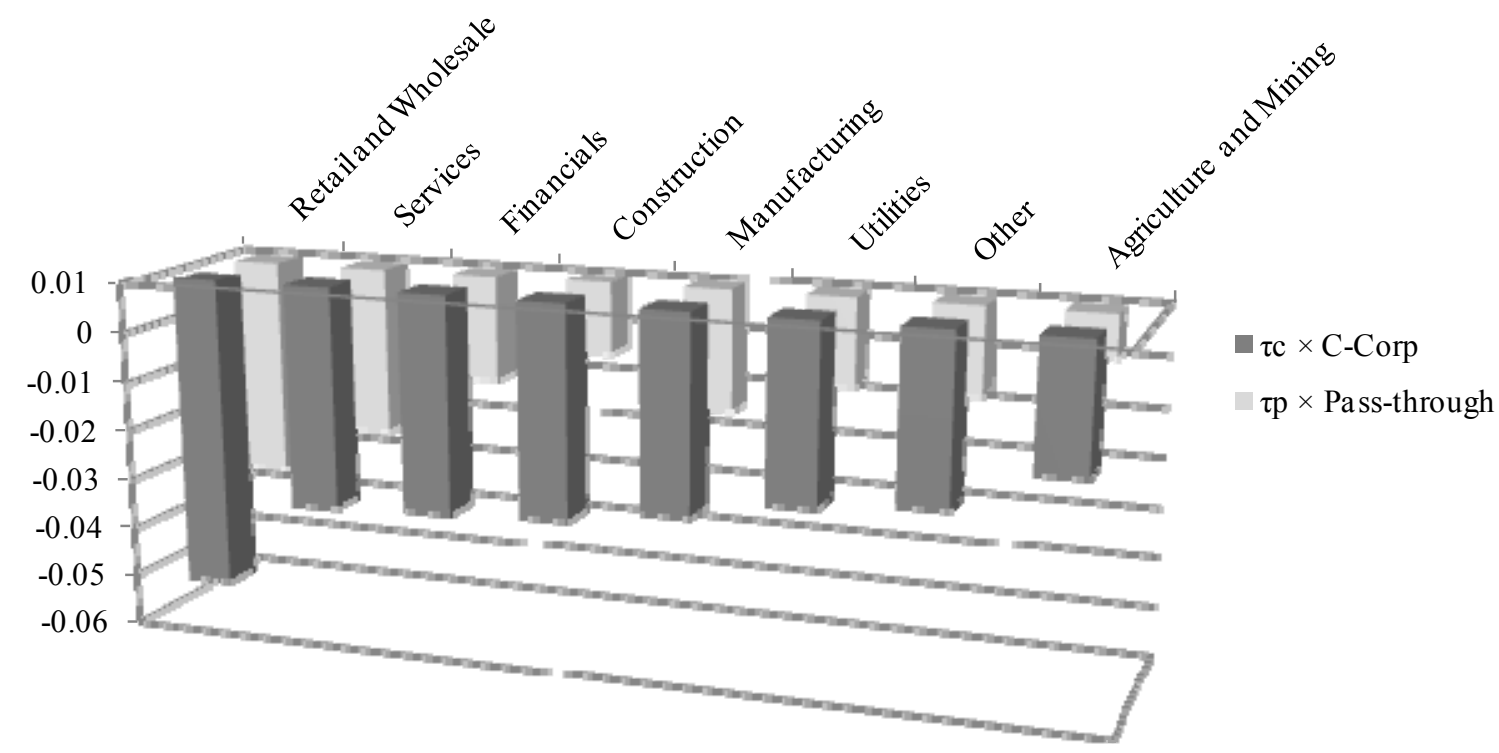

Panel (B): Intensive Margin

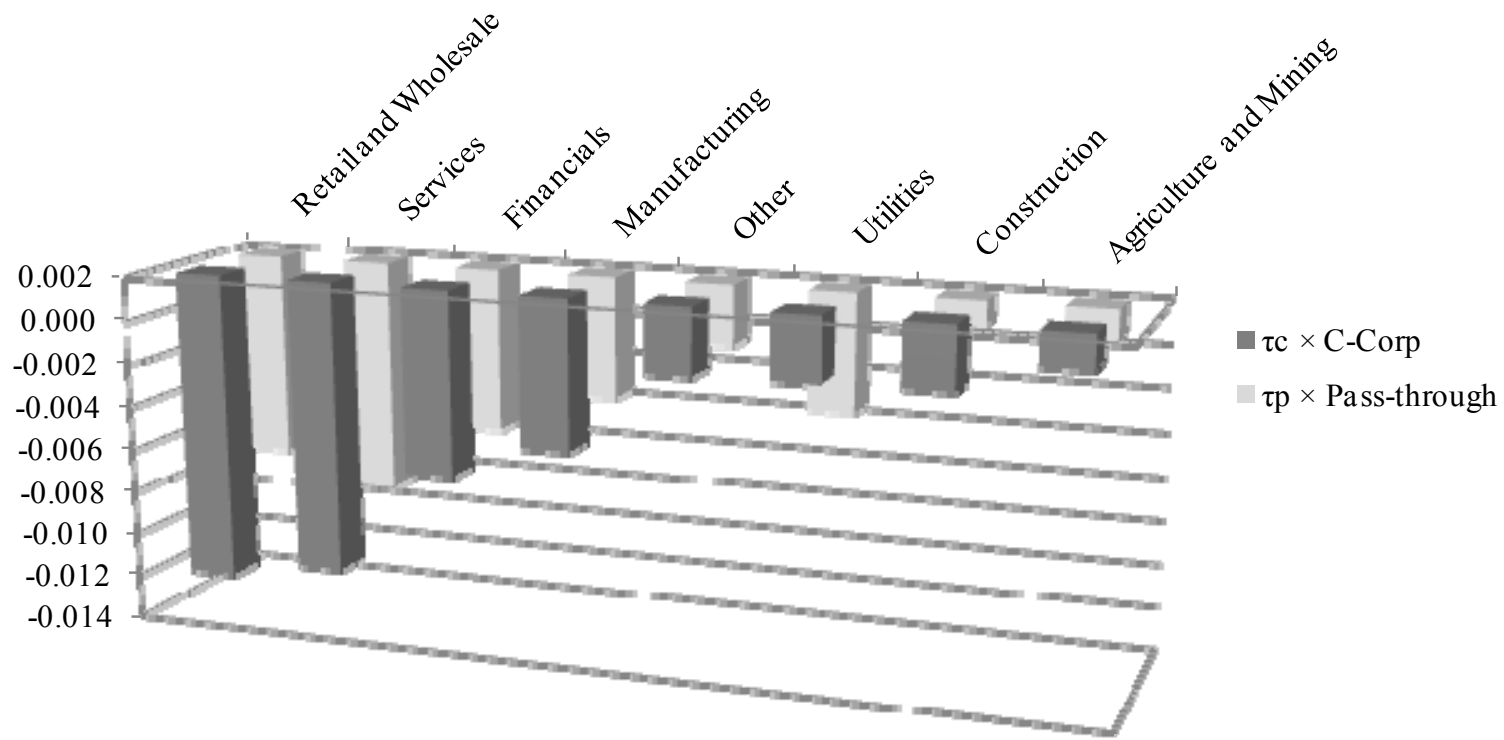




\section{Table 1. Summary Statistics}

In Panel (A), observations are at the establishment-year level. "All" refers to all establishments; "C-corp" refers to establishments belonging to C-corporations; "Pass-through" refers to establishments belonging to pass-through entities (S-corporations, partnerships, and sole proprietorships). "LBD" refers to establishments in the Longitudinal Business Database (LBD); "ASM/CMF" refers to establishments in the Annual Survey of Manufactures (ASM) and the Census of Manufactures (CMF). Capital stock is constructed using the perpetual inventory method, as explained in the appendix. In Panels (B) and (C), observations are aggregated into the firm-state-year and firm-year level, respectively. "Median" is the pseudo-median, which is computed as average across all observations between the $40^{\text {th }}$ and $60^{\text {th }}$ percentiles. The sample period is from 1977 to 2011.

Panel (A): Establishment Level

\begin{tabular}{|c|c|c|c|c|c|c|c|}
\hline & & \multicolumn{3}{|c|}{ LBD (all sectors) } & \multicolumn{3}{|c|}{ ASM/CMF (manufacturing) } \\
\hline & & All & C-corp & Pass-through & All & C-corp & Pass-through \\
\hline \multirow[t]{3}{*}{ \# Employees } & Mean & 49 & 50 & 36 & 311 & 318 & 153 \\
\hline & Median & 11 & 11 & 11 & 142 & 145 & 92 \\
\hline & Std. Dev. & 228 & 235 & 112 & 757 & 772 & 209 \\
\hline \multirow[t]{3}{*}{ Capital stock (\$ 1997) } & Mean & & & & 42,586 & 43,946 & 12,850 \\
\hline & Median & & & & 11,141 & 11,495 & 5,886 \\
\hline & Std. Dev. & & & & 170,941 & 174,555 & 31,723 \\
\hline Obs. & & $27,600,100$ & $25,271,400$ & $2,328,700$ & 854,700 & 817,300 & 37,400 \\
\hline
\end{tabular}

Panel (B): Firm-State Level

\begin{tabular}{|c|c|c|c|c|c|c|c|}
\hline & & \multicolumn{3}{|c|}{ LBD (all sectors) } & \multicolumn{3}{|c|}{ ASM/CMF (manufacturing) } \\
\hline & & All & C-corp & Pass-through & All & C-corp & Pass-through \\
\hline \multirow[t]{3}{*}{ \# Establishments } & Mean & 6.56 & 7.06 & 3.72 & 1.76 & 1.79 & 1.27 \\
\hline & Median & 1.25 & 1.26 & 1.21 & 1.00 & 1.00 & 1.00 \\
\hline & Std. Dev. & 25.67 & 27.37 & 11.54 & 1.94 & 1.99 & 0.88 \\
\hline \multirow[t]{3}{*}{ \# Employees } & Mean & 320 & 352 & 133 & 546 & 569 & 195 \\
\hline & Median & 58 & 61 & 46 & 201 & 210 & 107 \\
\hline & Std. Dev. & 1550 & 1,669 & 411 & 1,970 & 2,029 & 318 \\
\hline \multirow[t]{3}{*}{ Capital stock (\$1997) } & Mean & & & & 74,765 & 78,516 & 16,354 \\
\hline & Median & & & & 15,805 & 16,785 & 6,691 \\
\hline & Std. Dev. & & & & 362,123 & 373,066 & 47,513 \\
\hline Obs. & & $4,207,200$ & $3,580,600$ & 626,600 & 486,800 & 457,400 & 29,400 \\
\hline Obs. (including zeros) & & $32,997,200$ & $25,225,300$ & $7,771,900$ & $5,325,600$ & $4,758,400$ & 567,200 \\
\hline
\end{tabular}


Table 1

(Continued)

Panel (C): Firm Level

\begin{tabular}{|c|c|c|c|c|c|c|c|}
\hline & & \multicolumn{3}{|c|}{ LBD (all sectors) } & \multicolumn{3}{|c|}{ ASM/CMF (manufacturing) } \\
\hline & & All & C-corp & Pass-through & All & C-corp & Pass-through \\
\hline \multirow[t]{3}{*}{ \# States } & Mean & 6.50 & 7.24 & 4.11 & 4.66 & 4.90 & 2.64 \\
\hline & Median & 3.37 & 3.70 & 2.30 & 2.28 & 2.29 & 2.00 \\
\hline & Std. Dev. & 8.3 & 9.06 & 4.31 & 4.96 & 5.17 & 1.44 \\
\hline \multirow[t]{3}{*}{ \# Establishments } & Mean & 42.66 & 51.09 & 15.28 & 8.18 & 8.76 & 3.36 \\
\hline & Median & 8.04 & 8.41 & 6.25 & 3.36 & 3.70 & 2.32 \\
\hline & Std. Dev. & 239.83 & 269.31 & 88.43 & 15.02 & 15.76 & 2.67 \\
\hline \multirow[t]{3}{*}{ \# Employees } & Mean & 2,075 & 2,547 & 546 & 2,547 & 2,790 & 516 \\
\hline & Median & 359 & 417 & 252 & 683 & 767 & 295 \\
\hline & Std. Dev. & 11,841 & 13,480 & 1,583 & 9,251 & 9,756 & 715 \\
\hline \multirow[t]{3}{*}{ Capital stock (\$ 1997) } & Mean & & & & 348,551 & 384,950 & 43,204 \\
\hline & Median & & & & 49,606 & 57,151 & 18,885 \\
\hline & Std. Dev. & & & & $1,513,534$ & $1,596,842$ & 112,904 \\
\hline Obs. & & 647,000 & 494,600 & 152,400 & 104,400 & 93,300 & 11,100 \\
\hline
\end{tabular}




\section{Table 2. Tax Variables}

This table shows summary statistics for the tax variables used in the analysis. $\tau_{c}$ is the top corporate income tax rate (in $\%$ ). $\tau_{p}$ is the top personal income tax rate (in \%). Property tax share is the ratio of the total amount of property taxes (collected by the state and local governments) divided by total revenues (of the state and local governments). UI contribution is the top unemployment insurance (UI) rate multiplied by the maximum base wage (in \$). Tax incentives index is an index of tax incentives that adds one index point for each of the 33 tax incentives compiled in the Site Selection magazine. Sales tax rate is the sales tax rate in percentage points. Payroll apportionment factor is the apportionment percentage attributed to payroll in percentage points. Property apportionment factor and sales apportionment factor are defined similarly with respect to property and sales, respectively. Throwback is an indicator variable equal to one if the state has a throwback (or a throwout) rule. Summary statistics are computed using all available state-year observations from 1977 to 2011.

\begin{tabular}{lrrrrr}
\hline & \multicolumn{1}{c}{ Mean } & Std. Dev. & 25th Pctl. & 50th Pctl. & 75th Pctl. \\
& & & & & \\
& & & & & \\
$\tau_{\mathrm{c}}$ & 6.85 & 2.95 & 6.00 & 7.00 & 8.90 \\
$\tau_{\mathrm{p}}$ & 5.29 & 3.34 & 3.02 & 5.82 & 7.50 \\
Property tax share & 0.12 & 0.05 & 0.09 & 0.12 & 0.15 \\
UI contribution & 699 & 433 & 378 & 585 & 855 \\
Log(UI contribution) & 6.38 & 0.58 & 5.93 & 6.37 & 6.75 \\
Sales tax rate & 4.44 & 1.82 & 4.00 & 5.00 & 6.00 \\
Tax incentives index & 21.13 & 6.42 & 16.00 & 23.00 & 26.00 \\
Payroll apportionment factor & 26.82 & 9.95 & 25.00 & 33.33 & 33.33 \\
Property apportionment factor & 26.82 & 9.95 & 25.00 & 33.33 & 33.33 \\
Sales apportionment factor & 46.35 & 19.88 & 33.34 & 33.34 & 50.00 \\
Throwback rule & 0.60 & 0.49 & 0.00 & 1.00 & 1.00 \\
\hline
\end{tabular}




\section{Table 3. Correlation Matrix}

All variables are defined in Table 2. Panel (A) reports the correlation matrix based on the variables in level. Panel (B) reports the correlation matrix based on the variables in first differences.

Panel (A): Levels

(2)

(3)

(4)

(5)

(6)

(7)

(8)

(9)

(10)

(11)

(1) $\tau_{\mathrm{c}}$

(2) $\tau_{\mathrm{p}}$

(3) Property tax share

(4) UI contribution

(5) $\log ($ UI contribution)

(6) Sales tax rate

(7) Tax incentives index

(8) Payroll apportionment factor

(9) Property apportionment factor

(10) Sales apportionment factor

(11) Throwback rule

\begin{tabular}{|c|c|c|c|c|c|c|c|c|c|c|}
\hline 1.00 & & & & & & & & & & \\
\hline 0.21 & 1.00 & & & & & & & & & \\
\hline-0.03 & 0.08 & 1.00 & & & & & & & & \\
\hline 0.18 & 0.13 & -0.16 & 1.00 & & & & & & & \\
\hline 0.21 & 0.13 & -0.18 & 0.93 & 1.00 & & & & & & \\
\hline 0.07 & -0.02 & -0.24 & 0.05 & 0.06 & 1.00 & & & & & \\
\hline 0.21 & -0.04 & -0.24 & 0.28 & 0.38 & 0.25 & 1.00 & & & & \\
\hline-0.03 & 0.08 & 1.00 & -0.16 & -0.18 & -0.24 & -0.24 & 1.00 & & & \\
\hline-0.03 & 0.08 & 1.00 & -0.16 & -0.18 & -0.24 & -0.24 & 1.00 & 1.00 & & \\
\hline 0.03 & -0.08 & -1.00 & 0.16 & 0.18 & 0.24 & 0.24 & -1.00 & -1.00 & 1.00 & \\
\hline-0.21 & 0.07 & 0.21 & 0.01 & -0.02 & -0.21 & -0.15 & 0.21 & 0.21 & -0.21 & 1.00 \\
\hline
\end{tabular}

Panel (B): First Differences

(1)

(2)

(3)

(4)

(5)

(6)

(7)

(8)

(9)

(10)

(11)
(1) $\Delta \tau_{\mathrm{c}}$
(2) $\Delta \tau_{\mathrm{p}}$
(3) $\Delta$ Property tax share
(4) $\Delta$ UI contribution
(5) $\Delta \log ($ UI contribution)
(6) $\Delta$ Sales tax rate
(7) $\Delta$ Tax incentives index
(8) $\Delta$ Payroll apportionment factor
(9) $\Delta$ Property apportionment factor
(10) $\Delta$ Sales apportionment factor
(11) $\Delta$ Throwback rule

1.00

0.04

0.07

0.01

0.04

0.09

0.01

0.04

0.04

1.00
0.08
0.01
0.02
0.04
-0.01
-0.02
-0.02
0.02
0.03

1.00
-0.05
-0.05
0.00
-0.02
-0.05
-0.05
0.05
0.06

1.00
0.85
0.01
0.05
0.03
0.03
-0.03
0.04

1.00
0.01
0.06
0.04
0.04
-0.04
0.04
0.02
$-0.02$

1.00

$0.00 \quad 1.00$

$0.02 \quad 0.00$

0.08

0.04

0.00
0.00

1.00

$-1.00-1.00$ 


\section{Table 4. Extensive Margin: Main Results}

The dependent variable is the number of establishments of a given firm in a given state and year. The number of establishments is set to zero if an active company has no operation in the state. C-Corp is a dummy variable that equals one if a company is a C-corporation, and Pass-through is a dummy variable that equals one if a company is an S-corporation, partnership, or sole proprietorship for tax purposes. GDP is the state's gross domestic product (from the BEA). Other variables are defined in Table 2. All regressions include dummy variables for $\mathrm{MI}$, OH (post2005), TX (post-1991), and WA, interacted with C-Corp and Pass-through. The sample period is from 1977 to 2011. Standard errors are clustered at the state level. *,**, and *** denotes significance at the $10 \%, 5 \%$, and $1 \%$ level, respectively.

\section{\# Establishments}

(1)

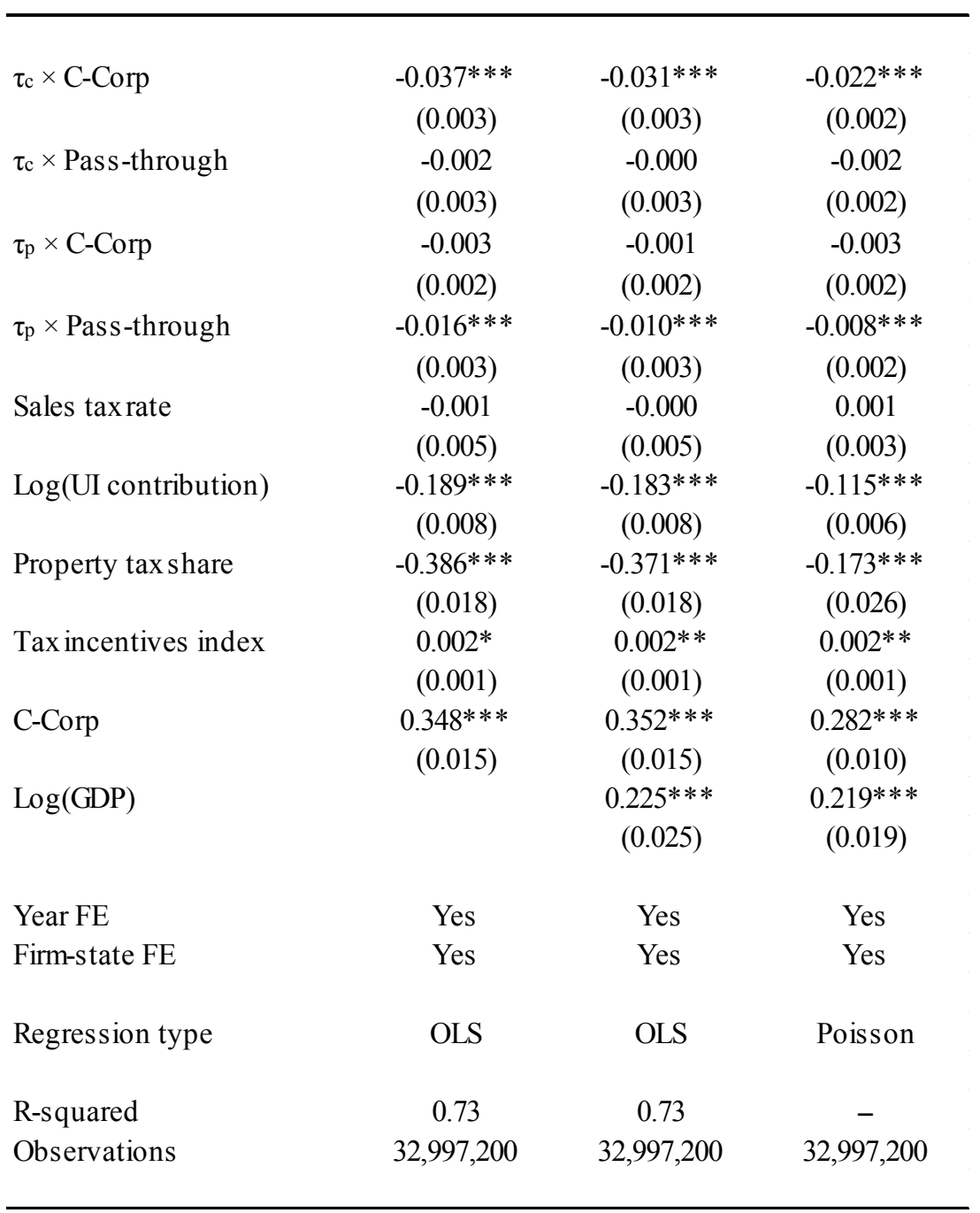

(3) 


\section{Table 5. Extensive Margin: Robustness}

This table presents variants of the baseline specification presented in column (2) of Table 4. In column (1), the regression includes region by year fixed effects. Regions are partitioned according to the nine Census regions. In column (2), the regression includes industry-by-year fixed effects. Industries are partitioned according to 2-digit SIC codes. In column (3), the regression includes legal form of organization LFO-by-year fixed effects, where LFO is the Legal Form of Organization-C-Corp or Pass-through. In column (4), we exclude firm-year observations within a five-year window around a change in LFO. In column (5), we replace $\tau_{\mathrm{c}}$ and $\tau_{\mathrm{p}}$ by their respective residuals from the predictive regressions provided in Appendix Table A3. In column (6), the sample is restricted to companies with coverage in the ASM/CMF. In column (7), the dependent variable is an indicator variable equal to one if the company has at least one establishment in the state. The sample period is from 1977 to 2011. Standard errors are clustered at the state level. *,**, and $* * *$ denotes significance at the $10 \%, 5 \%$, and $1 \%$ level, respectively.

\begin{tabular}{|c|c|c|c|c|c|c|c|}
\hline & \multicolumn{6}{|c|}{ \# Establishments } & \multirow{2}{*}{$\begin{array}{c}\text { I(\# Establ. >0) } \\
\text { "Extensive- } \\
\text { extensive" } \\
\text { margin }\end{array}$} \\
\hline & $\begin{array}{l}\text { Regional } \\
\text { trends }\end{array}$ & $\begin{array}{l}\text { Industry } \\
\text { trends }\end{array}$ & $\begin{array}{l}\text { LFO } \\
\text { trends }\end{array}$ & $\begin{array}{l}\text { Excluding 5-year } \\
\text { window around } \\
\text { LFO change }\end{array}$ & $\begin{array}{l}\text { Unpredicted } \\
\text { component of } \\
\tau_{\mathrm{c}} \text { and } \tau_{\mathrm{p}}\end{array}$ & $\begin{array}{l}\text { ASM/CMF } \\
\text { manufacturing) }\end{array}$ & \\
\hline & (1) & (2) & (3) & (4) & (5) & (6) & (7) \\
\hline$\tau_{\mathrm{c}} \times$ C-Corp & $\begin{array}{c}-0.032 * * * \\
(0.003)\end{array}$ & $\begin{array}{c}-0.026^{* * * *} \\
(0.003)\end{array}$ & $\begin{array}{c}-0.029 * * * \\
(0.003)\end{array}$ & $\begin{array}{c}-0.029 * * * \\
(0.003)\end{array}$ & $\begin{array}{c}-0.030 * * * \\
(0.003)\end{array}$ & $\begin{array}{c}-0.019 * * \\
(0.008)\end{array}$ & $\begin{array}{c}-0.0031 * * * \\
(0.0012)\end{array}$ \\
\hline$\tau_{\mathrm{c}} \times$ Pass-through & $\begin{array}{c}0.002 \\
(0.002)\end{array}$ & $\begin{array}{c}0.001 \\
(0.003)\end{array}$ & $\begin{array}{c}0.001 \\
(0.002)\end{array}$ & $\begin{array}{l}-0.001 \\
(0.003)\end{array}$ & $\begin{array}{l}-0.001 \\
(0.003)\end{array}$ & $\begin{array}{c}0.005 \\
(0.007)\end{array}$ & $\begin{array}{c}0.0010 \\
(0.0013)\end{array}$ \\
\hline$\tau_{\mathrm{p}} \times$ C-Corp & $\begin{array}{c}0.001 \\
(0.002)\end{array}$ & $\begin{array}{c}0.001 \\
(0.002)\end{array}$ & $\begin{array}{l}-0.001 \\
(0.002)\end{array}$ & $\begin{array}{l}-0.002 \\
(0.002)\end{array}$ & $\begin{array}{l}-0.002 \\
(0.002)\end{array}$ & $\begin{array}{c}0.001 \\
(0.003)\end{array}$ & $\begin{array}{c}0.0008 \\
(0.0005)\end{array}$ \\
\hline$\tau_{\mathrm{p}} \times$ Pass-through & $\begin{array}{c}-0.013 * * * \\
(0.003)\end{array}$ & $\begin{array}{c}-0.006 * * \\
(0.003)\end{array}$ & $\begin{array}{c}-0.014 * * * \\
(0.003)\end{array}$ & $\begin{array}{c}-0.009 * * * \\
(0.003)\end{array}$ & $\begin{array}{c}-0.009 * * * \\
(0.003)\end{array}$ & $\begin{array}{l}-0.012 * \\
(0.007)\end{array}$ & $\begin{array}{l}-0.0021^{*} \\
(0.0012)\end{array}$ \\
\hline Sales tax rate & $\begin{array}{l}-0.001 \\
(0.005)\end{array}$ & $\begin{array}{l}-0.003 \\
(0.005)\end{array}$ & $\begin{array}{l}-0.000 \\
(0.005)\end{array}$ & $\begin{array}{l}-0.008 \\
(0.005)\end{array}$ & $\begin{array}{c}0.008 \\
(0.005)\end{array}$ & $\begin{array}{c}0.004 \\
(0.012)\end{array}$ & $\begin{array}{c}0.0013 \\
(0.0013)\end{array}$ \\
\hline $\log (\mathrm{UI}$ contribution) & $\begin{array}{c}-0.195 * * * \\
(0.008)\end{array}$ & $\begin{array}{c}-0.192 * * * \\
(0.008)\end{array}$ & $\begin{array}{c}-0.184 * * * \\
(0.008)\end{array}$ & $\begin{array}{c}-0.176^{* * * *} \\
(0.008)\end{array}$ & $\begin{array}{c}-0.173 * * * \\
(0.008)\end{array}$ & $\begin{array}{c}-0.074 * * * \\
(0.020)\end{array}$ & $\begin{array}{c}-0.0084 * * * \\
(0.0026)\end{array}$ \\
\hline Property tax share & $\begin{array}{c}-0.360 * * * \\
(0.019)\end{array}$ & $\begin{array}{c}-0.387 * * * \\
(0.021)\end{array}$ & $\begin{array}{c}-0.371 * * * \\
(0.017)\end{array}$ & $\begin{array}{c}-0.345^{* * *} \\
(0.018)\end{array}$ & $\begin{array}{c}-0.389 * * * \\
(0.019)\end{array}$ & $\begin{array}{c}-0.062 * * \\
(0.030)\end{array}$ & $\begin{array}{c}-0.0267 * * * \\
(0.0079)\end{array}$ \\
\hline Tax incentives index & $\begin{array}{c}0.003 * * * \\
(0.001)\end{array}$ & $\begin{array}{l}0.002 * \\
(0.001)\end{array}$ & $\begin{array}{c}0.002 * * \\
(0.001)\end{array}$ & $\begin{array}{c}0.002 * * \\
(0.001)\end{array}$ & $\begin{array}{c}0.002 * * \\
(0.001)\end{array}$ & $\begin{array}{l}0.003^{*} \\
(0.002)\end{array}$ & $\begin{array}{c}0.0001 \\
(0.0002)\end{array}$ \\
\hline C-Corp & $\begin{array}{c}0.339 * * * \\
(0.014)\end{array}$ & $\begin{array}{c}0.346^{* * *} \\
(0.014)\end{array}$ & & $\begin{array}{c}0.345^{* * *} \\
(0.015)\end{array}$ & $\begin{array}{c}0.341 * * * \\
(0.014)\end{array}$ & $\begin{array}{c}0.147 * * * \\
(0.041)\end{array}$ & $\begin{array}{c}0.0150 * * \\
(0.0064)\end{array}$ \\
\hline $\log (\mathrm{GDP})$ & $\begin{array}{c}0.213 * * * \\
(0.025)\end{array}$ & $\begin{array}{c}0.243 * * * \\
(0.024)\end{array}$ & $\begin{array}{c}0.224 * * * \\
(0.023)\end{array}$ & $\begin{array}{c}0.239 * * * \\
(0.025)\end{array}$ & $\begin{array}{c}0.265^{* * *} \\
(0.023)\end{array}$ & $\begin{array}{c}0.523 * * * \\
(0.052)\end{array}$ & $\begin{array}{c}0.0402 * * * \\
(0.0057)\end{array}$ \\
\hline Year FE & Yes & Yes & Yes & Yes & Yes & Yes & Yes \\
\hline Firm-s tate FE & Yes & Yes & Yes & Yes & Yes & Yes & Yes \\
\hline Region $\times$ year FE & Yes & No & No & No & No & No & No \\
\hline Industry $\times$ year FE & No & Yes & No & No & No & No & No \\
\hline $\mathrm{LFO} \times$ year FE & No & No & Yes & No & No & No & No \\
\hline R-squared & 0.76 & 0.76 & 0.76 & 0.75 & 0.74 & 0.77 & 0.75 \\
\hline Observations & $32,997,200$ & $32,997,200$ & $32,997,200$ & $30,288,100$ & $32,398,000$ & $5,325,600$ & $32,997,200$ \\
\hline
\end{tabular}


Table 6. Extensive Margin: Reallocation

This table presents variants of the regressions presented in columns (2) and (3) of Table 4. $\tilde{\tau}_{C}$ (other states) refers to the average corporate income tax rate in all other states in which the company has operations. The average is computed using the share of the company's employees in each state as weights. The other tax items referring to "other states" are computed analogously. The sample period is from 1977 to 2011 . Standard errors are clustered at the state level. *, **, and $* * *$ denotes significance at the $10 \%, 5 \%$, and $1 \%$ level, respectively.

\begin{tabular}{|c|c|c|}
\hline & \multicolumn{2}{|c|}{ \# Establishments } \\
\hline & (1) & (2) \\
\hline$\tau_{\mathrm{c}} \times$ C-Corp & $\begin{array}{c}-0.031 * * * \\
(0.003)\end{array}$ & $\begin{array}{c}-0.024 * * * \\
(0.002)\end{array}$ \\
\hline$\tau_{c} \times$ Pass-through & $\begin{array}{l}-0.000 \\
(0.003)\end{array}$ & $\begin{array}{l}-0.001 \\
(0.002)\end{array}$ \\
\hline$\tau_{\mathrm{p}} \times$ C-Corp & $\begin{array}{l}-0.001 \\
(0.002)\end{array}$ & $\begin{array}{l}-0.002 \\
(0.002)\end{array}$ \\
\hline$\tau_{\mathrm{p}} \times$ Pass-through & $\begin{array}{c}-0.010^{* * *} \\
(0.003)\end{array}$ & $\begin{array}{c}-0.009 * * * \\
(0.002)\end{array}$ \\
\hline Sales tax rate & $\begin{array}{l}-0.000 \\
(0.005)\end{array}$ & $\begin{array}{c}0.001 \\
(0.003)\end{array}$ \\
\hline $\log (\mathrm{UI}$ contribution $)$ & $\begin{array}{c}-0.189^{* * * *} \\
(0.008)\end{array}$ & $\begin{array}{c}-0.115^{* * *} \\
(0.007)\end{array}$ \\
\hline Property tax share & $\begin{array}{c}-0.372 * * * \\
(0.018)\end{array}$ & $\begin{array}{c}-0.175^{* * *} \\
(0.027)\end{array}$ \\
\hline Tax incentives index & $\begin{array}{c}0.002 * * \\
(0.001)\end{array}$ & $\begin{array}{c}0.002 * * \\
(0.001)\end{array}$ \\
\hline$\tilde{\tau}_{\mathrm{c}}($ other states $) \times$ C-Corp & $\begin{array}{c}0.016^{* * *} \\
(0.002)\end{array}$ & $\begin{array}{c}0.009 * * * \\
(0.003)\end{array}$ \\
\hline$\tilde{\tau}_{\mathrm{c}}$ (other states) $\times$ Pass-through & $\begin{array}{l}-0.001 \\
(0.002)\end{array}$ & $\begin{array}{l}-0.000 \\
(0.002)\end{array}$ \\
\hline$\tilde{\tau}_{\mathrm{p}}($ other states $) \times$ C-Corp & $\begin{array}{c}0.001 \\
(0.002)\end{array}$ & $\begin{array}{l}-0.001 \\
(0.002)\end{array}$ \\
\hline$\tilde{\tau}_{\mathrm{p}}$ (other states) $\times$ Pass-through & $\begin{array}{l}0.005^{* *} \\
(0.002)\end{array}$ & $\begin{array}{l}0.004^{*} \\
(0.002)\end{array}$ \\
\hline Sales tax rate (other states) & $\begin{array}{l}-0.001 \\
(0.003)\end{array}$ & $\begin{array}{l}-0.000 \\
(0.004)\end{array}$ \\
\hline Log(UI contribution) (other states) & $\begin{array}{c}0.117^{* * *} \\
(0.008)\end{array}$ & $\begin{array}{c}0.052 * * * \\
(0.007)\end{array}$ \\
\hline Property tax share (other states) & $\begin{array}{c}0.227^{* * * *} \\
(0.029)\end{array}$ & $\begin{array}{c}0.113^{* * *} \\
(0.021)\end{array}$ \\
\hline Tax incentives index (other states) & $\begin{array}{l}-0.001 \\
(0.001)\end{array}$ & $\begin{array}{l}-0.000 \\
(0.001)\end{array}$ \\
\hline C-Corp & $\begin{array}{c}0.479 * * * \\
(0.021)\end{array}$ & $\begin{array}{c}0.282 * * * \\
(0.010)\end{array}$ \\
\hline $\log (\mathrm{GDP})$ & $\begin{array}{c}0.225^{* * *} \\
(0.025)\end{array}$ & $\begin{array}{c}0.220^{* * * *} \\
(0.019)\end{array}$ \\
\hline $\begin{array}{l}\text { Year FE } \\
\text { Firm-state FE }\end{array}$ & $\begin{array}{l}\text { Yes } \\
\text { Yes }\end{array}$ & $\begin{array}{l}\text { Yes } \\
\text { Yes }\end{array}$ \\
\hline Regression type & OLS & Poisson \\
\hline R-squared & 0.73 & - \\
\hline Observations & $32,997,200$ & $32,997,200$ \\
\hline
\end{tabular}




\section{Table 7. Intensive Margin: Main Results}

This table presents variants of the regressions in Tables 4 and 6, except that the analysis is conducted at the intensive margin. The unit of observation is the establishment-year. The dependent variable is the logarithm of the number of employees at the establishment. The sample period is from 1977 to 2011. Standard errors are clustered at the state level. *,**, and *** denotes significance at the $10 \%, 5 \%$, and $1 \%$ level, respectively.

\begin{tabular}{|c|c|c|c|}
\hline & \multicolumn{3}{|c|}{$\log ($ employees $)$} \\
\hline & (1) & (2) & (3) \\
\hline$\tau_{\mathrm{c}} \times$ C-Corp & $\begin{array}{c}-0.0041 * * * \\
(0.0005)\end{array}$ & $\begin{array}{c}-0.0038^{* * *} \\
(0.0005)\end{array}$ & $\begin{array}{c}-0.0042 * * * \\
(0.0005)\end{array}$ \\
\hline$\tau_{c} \times$ Pass-through & $\begin{array}{c}-0.0004 \\
(0.0010)\end{array}$ & $\begin{array}{l}-0.0001 \\
(0.0010)\end{array}$ & $\begin{array}{c}0.0002 \\
(0.0011)\end{array}$ \\
\hline$\tau_{\mathrm{p}} \times$ C-Corp & $\begin{array}{l}-0.0007 \\
(0.0004)\end{array}$ & $\begin{array}{l}-0.0003 \\
(0.0004)\end{array}$ & $\begin{array}{l}-0.0003 \\
(0.0004)\end{array}$ \\
\hline$\tau_{\mathrm{p}} \times$ Pass-through & $\begin{array}{c}-0.0024 * * * \\
(0.0009)\end{array}$ & $\begin{array}{c}-0.0019^{* *} \\
(0.0009)\end{array}$ & $\begin{array}{c}-0.0017^{*} \\
(0.0010)\end{array}$ \\
\hline Sales tax rate & $\begin{array}{l}-0.0003 \\
(0.0007)\end{array}$ & $\begin{array}{l}-0.0003 \\
(0.0007)\end{array}$ & $\begin{array}{l}-0.0003 \\
(0.0007)\end{array}$ \\
\hline $\log ($ UI contribution $)$ & $\begin{array}{c}-0.0223^{* * *} * \\
(0.0009)\end{array}$ & $\begin{array}{c}-0.0110^{* * *} \\
(0.0014)\end{array}$ & $\begin{array}{c}-0.0102 * * * \\
(0.0015)\end{array}$ \\
\hline Property tax share & $\begin{array}{c}-0.0128 \\
(0.0107)\end{array}$ & $\begin{array}{c}-0.0032 \\
(0.0107)\end{array}$ & $\begin{array}{l}-0.0079 \\
(0.0115)\end{array}$ \\
\hline Tax incentives index & $\begin{array}{c}0.0008 * * * \\
(0.0001)\end{array}$ & $\begin{array}{c}0.0009 * * * \\
(0.0001)\end{array}$ & $\begin{array}{c}0.0008^{* * *} * \\
(0.0002)\end{array}$ \\
\hline$\tilde{\tau}_{\mathrm{c}}($ other states $) \times$ C-Corp & & & $\begin{array}{c}0.0020^{* * *} \\
(0.0006)\end{array}$ \\
\hline$\tilde{\tau}_{\mathrm{c}}($ other states $) \times$ Pass-through & & & $\begin{array}{l}-0.0003 \\
(0.0013)\end{array}$ \\
\hline$\tilde{\tau}_{p}($ other states $) \times$ C-Corp & & & $\begin{array}{l}-0.0001 \\
(0.0006)\end{array}$ \\
\hline$\tilde{\tau}_{\mathrm{p}}($ other states $) \times$ Pass-through & & & $\begin{array}{c}0.0008 \\
(0.0014)\end{array}$ \\
\hline Sales tax rate (other states) & & & $\begin{array}{l}-0.0004 \\
(0.0012)\end{array}$ \\
\hline $\log ($ UI contribution) (other states) & & & $\begin{array}{l}0.0048^{*} \\
(0.0028)\end{array}$ \\
\hline Property tax share (other states) & & & $\begin{array}{c}0.0032 \\
(0.0025)\end{array}$ \\
\hline Tax incentives index (other states) & & & $\begin{array}{c}0.0003 \\
(0.0003)\end{array}$ \\
\hline C-Corp & $\begin{array}{c}0.0015 \\
(0.0051)\end{array}$ & $\begin{array}{c}0.0028 \\
(0.0051)\end{array}$ & $\begin{array}{c}-0.0104 \\
(0.0078)\end{array}$ \\
\hline $\log (\mathrm{GDP})$ & & $\begin{array}{c}0.2417 * * * \\
(0.0054)\end{array}$ & $\begin{array}{c}0.2411^{* * * *} \\
(0.0054)\end{array}$ \\
\hline Year FE & Yes & Yes & Yes \\
\hline Establishment FE & Yes & Yes & Yes \\
\hline R-squared & 0.88 & 0.88 & 0.88 \\
\hline Observations & $27,600,100$ & $27,600,100$ & $27,600,100$ \\
\hline
\end{tabular}




\section{Table 8. Intensive Margin: Robustness}

This table presents regressions similar to those in Table 5, except that the analysis is conducted at the intensive margin. The unit of observation is the establishment-year. The dependent variable is the logarithm of the number of employees at the establishment. The sample period is from 1977 to 2011. Standard errors are clustered at the state level. *,**, and $* * *$ denotes significance at the $10 \%, 5 \%$, and $1 \%$ level, respectively.

\begin{tabular}{|c|c|c|c|c|c|}
\hline & \multicolumn{5}{|c|}{$\log ($ employees $)$} \\
\hline & $\begin{array}{c}\text { Regional } \\
\text { trends }\end{array}$ & $\begin{array}{l}\text { Industry } \\
\text { trends }\end{array}$ & $\begin{array}{l}\text { LFO } \\
\text { trends }\end{array}$ & $\begin{array}{c}\text { Excluding 5-year } \\
\text { window around } \\
\text { LFO change }\end{array}$ & $\begin{array}{c}\text { Unpredicted } \\
\text { component of } \\
\tau_{\mathrm{c}} \text { and } \tau_{\mathrm{p}}\end{array}$ \\
\hline & (1) & (2) & (3) & (4) & (5) \\
\hline$\tau_{c} \times$ C-Corp & $\begin{array}{c}-0.0048 * * * \\
(0.0005)\end{array}$ & $\begin{array}{c}-0.0031 * * * \\
(0.0005)\end{array}$ & $\begin{array}{c}-0.0041 * * * \\
(0.0004)\end{array}$ & $\begin{array}{c}-0.0038^{* * *} \\
(0.0005)\end{array}$ & $\begin{array}{c}-0.0039 * * * \\
(0.0005)\end{array}$ \\
\hline$\tau_{c} \times$ Pass-through & $\begin{array}{c}-0.0012 \\
(0.0009)\end{array}$ & $\begin{array}{l}-0.0011 \\
(0.0009)\end{array}$ & $\begin{array}{c}-0.0002 \\
(0.0009)\end{array}$ & $\begin{array}{c}-0.0002 \\
(0.0010)\end{array}$ & $\begin{array}{l}-0.0005 \\
(0.0010)\end{array}$ \\
\hline$\tau_{\mathrm{p}} \times$ C-Corp & $\begin{array}{c}-0.0001 \\
(0.0004)\end{array}$ & $\begin{array}{c}0.0001 \\
(0.0004)\end{array}$ & $\begin{array}{c}-0.0001 \\
(0.0004)\end{array}$ & $\begin{array}{c}-0.0003 \\
(0.0004)\end{array}$ & $\begin{array}{l}-0.0006 \\
(0.0004)\end{array}$ \\
\hline$\tau_{\mathrm{p}} \times$ Pass-through & $\begin{array}{c}-0.0017 * * \\
(0.0008)\end{array}$ & $\begin{array}{c}-0.0016^{*} \\
(0.0008)\end{array}$ & $\begin{array}{c}-0.0019 * * \\
(0.0008)\end{array}$ & $\begin{array}{c}-0.0020 * * \\
(0.0009)\end{array}$ & $\begin{array}{c}-0.0015^{*} \\
(0.0009)\end{array}$ \\
\hline Sales tax rate & $\begin{array}{l}-0.0004 \\
(0.0007)\end{array}$ & $\begin{array}{l}-0.0010 \\
(0.0007)\end{array}$ & $\begin{array}{c}-0.0002 \\
(0.0006)\end{array}$ & $\begin{array}{c}0.0008 \\
(0.0007)\end{array}$ & $\begin{array}{l}-0.0003 \\
(0.0007)\end{array}$ \\
\hline $\log (\mathrm{UI}$ contribution $)$ & $\begin{array}{c}-0.0110 * * * \\
(0.0015)\end{array}$ & $\begin{array}{c}-0.0117 * * * \\
(0.0015)\end{array}$ & $\begin{array}{c}-0.0119 * * * \\
(0.0013)\end{array}$ & $\begin{array}{c}-0.0057 * * * \\
(0.0015)\end{array}$ & $\begin{array}{c}-0.0103^{* * *} * \\
(0.0014)\end{array}$ \\
\hline Property tax share & $\begin{array}{l}-0.0017 \\
(0.0100)\end{array}$ & $\begin{array}{l}-0.0095 \\
(0.0102)\end{array}$ & $\begin{array}{l}-0.0062 \\
(0.0098)\end{array}$ & $\begin{array}{l}-0.0072 \\
(0.0106)\end{array}$ & $\begin{array}{l}-0.0099 \\
(0.0110)\end{array}$ \\
\hline Tax incentives index & $\begin{array}{c}0.0008 * * * \\
(0.0001)\end{array}$ & $\begin{array}{c}0.0008 * * * \\
(0.0001)\end{array}$ & $\begin{array}{c}0.0009 * * * \\
(0.0001)\end{array}$ & $\begin{array}{c}0.0006^{* * *} \\
(0.0002)\end{array}$ & $\begin{array}{c}0.0009 * * * \\
(0.0001)\end{array}$ \\
\hline C-Corp & $\begin{array}{c}0.0025 \\
(0.0046)\end{array}$ & $\begin{array}{c}0.0027 \\
(0.0046)\end{array}$ & & $\begin{array}{c}0.0013 \\
(0.0052)\end{array}$ & $\begin{array}{c}0.0032 \\
(0.0050)\end{array}$ \\
\hline $\log (\mathrm{GDP})$ & $\begin{array}{c}0.2524 * * * \\
(0.0054)\end{array}$ & $\begin{array}{c}0.2468 * * * \\
(0.0053)\end{array}$ & $\begin{array}{c}0.2434 * * * \\
(0.0049)\end{array}$ & $\begin{array}{c}0.2457 * * * \\
(0.0055)\end{array}$ & $\begin{array}{c}0.2368^{* * *} * \\
(0.0055)\end{array}$ \\
\hline Year FE & Yes & Yes & Yes & Yes & Yes \\
\hline Establishment FE & Yes & Yes & Yes & Yes & Yes \\
\hline Region $\times$ year FE & Yes & No & No & No & No \\
\hline Industry $\times$ year FE & No & Yes & No & No & No \\
\hline $\mathrm{LFO} \times$ year FE & No & No & Yes & No & No \\
\hline R-squared & 0.90 & 0.90 & 0.88 & 0.88 & 0.88 \\
\hline Observations & $27,600,100$ & $27,600,100$ & $27,600,100$ & $26,416,300$ & $27,175,000$ \\
\hline
\end{tabular}




\section{Table 9. Extensive Margin: Difference-in-Differences Analysis of Large Tax Changes}

This table estimates the treatment effect of large tax changes (increases or decreases in tax rates that are at least 100 basis points) on the number of establishments. In columns (1) and (2), the treatments are large decreases in the corporate income tax rate. The sample includes all firm-state-year observations in the treated states three years before and after the treatments (i.e., the treatment group consists of C-corporations; the control group consists of pass-through entities). In column (1), Treatment is a dummy variable equal to one for C-corporations in the years following the treatment. In column (2), Treatment(-2) is a dummy variable equal to one for C-corporations two years prior to the treatment. Treatment $(-1)$, Treatment $(0)$, Treatment $(+1)$, and Treatment $(+2)$ are defined similarly. The analysis in columns (3)-(8) is conducted analogously with respect to large increases in the corporate income tax rate and large decreases/increases in the personal income tax rate, respectively. The sample period is from 1977 to 2011 . Standard errors are clustered at the state level. *, **, and *** denotes significance at the $10 \%, 5 \%$, and $1 \%$ level, respectively.

\# Establishments

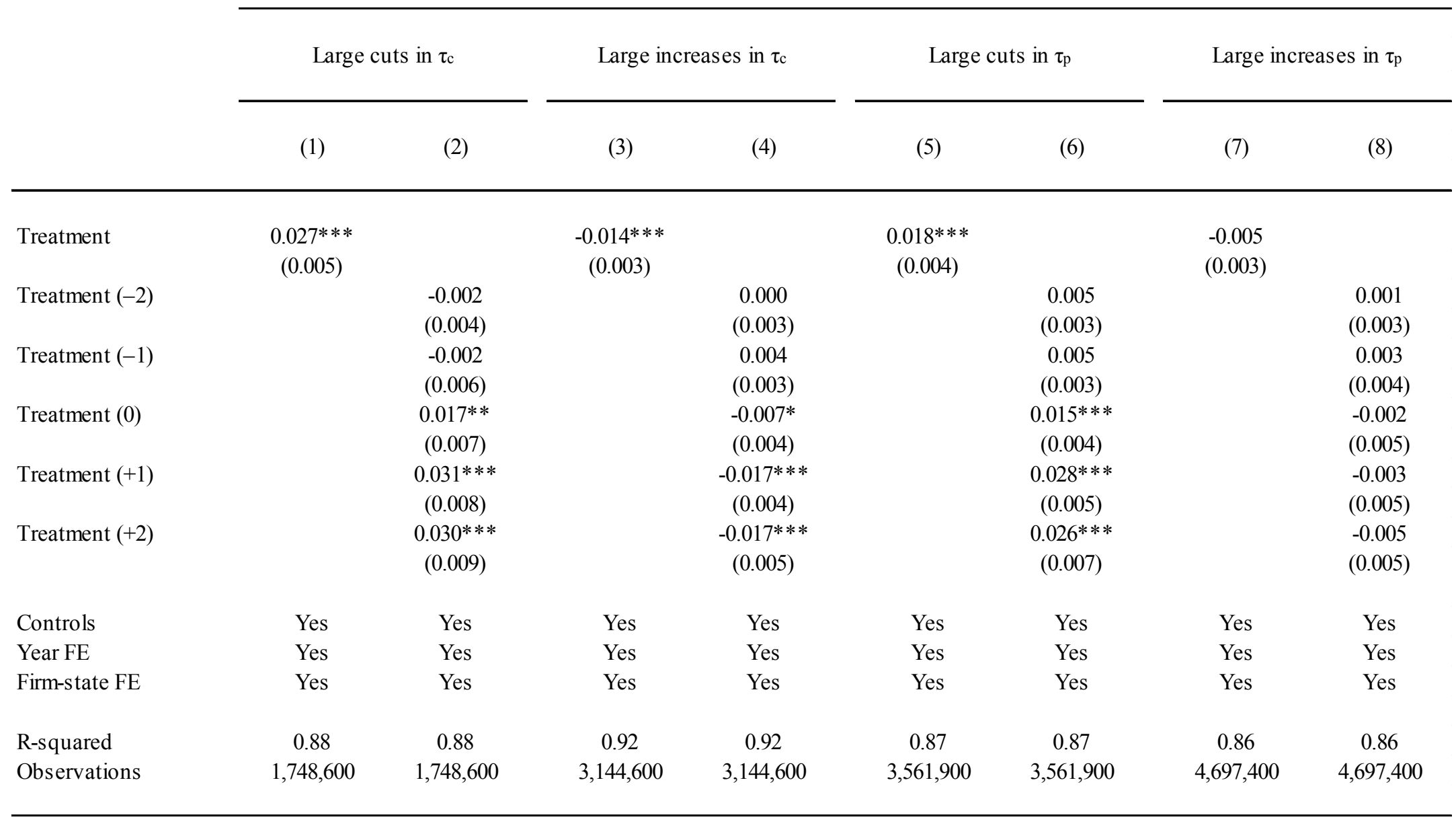


Table 10. Extensive Margin: Difference-in-Differences Analysis of Large Tax Changes_Textual Analysis

This table presents variants of the regressions in columns (1), (3), (5), and (7) of Table 9, decomposing the treatment into exogenous, endogenous, and other types of treatments using the methodology of Romer and Romer (2010). ERTA81 refers to the Economic Recovery Tax Act of 1981; TRA86 refers to the Tax Reform Act of 1986. The sample period is from 1977 to 2011 . Standard errors are clustered at the state level. *, **, and *** denotes significance at the $10 \%, 5 \%$, and $1 \%$ level, respectively.

Panel (A): Romer and Romer (2010) Classification

\begin{tabular}{lrr}
\hline & & $\tau_{\mathrm{c}}$ \\
\cline { 2 - 3 } (1) Offsetting a change in government spending (endogenous) & 6 & 7 \\
(2) Offsetting some factor other than spending likely to affect output (endogenous) & 6 & 5 \\
(3) Dealing with an inherited budget deficit (exogenous) & 7 & 34 \\
(4) Achieving some long-run goal (exogenous) & 18 & 24 \\
(5) Unclassified & 19 & 35 \\
\cline { 2 - 3 } Total & 56 & 105 \\
\hline
\end{tabular}

Panel (B): Difference-in-Differences Analysis

\# Establishments

\begin{tabular}{|c|c|c|c|c|c|c|c|}
\hline & \multirow{2}{*}{$\frac{\text { Large cuts in } \tau_{c}}{\text { (1) }}$} & \multicolumn{2}{|c|}{ Large increases in $\tau_{c}$} & \multicolumn{2}{|c|}{ Large cuts in $\tau_{\mathrm{p}}$} & \multicolumn{2}{|c|}{ Large increases in $\tau_{p}$} \\
\hline & & (2) & (3) & (4) & (5) & (6) & (7) \\
\hline Treatment (exogenous) & $\begin{array}{c}0.029 * * * \\
(0.007)\end{array}$ & $\begin{array}{c}-0.016^{* * *} \\
(0.005)\end{array}$ & & $\begin{array}{c}0.019 * * * \\
(0.005)\end{array}$ & & $\begin{array}{l}-0.005 \\
(0.005)\end{array}$ & \\
\hline Treatment (ERTA81) & & & $\begin{array}{c}-0.014 * * \\
(0.007)\end{array}$ & & & & \\
\hline Treatment (TRA86) & & & & & $\begin{array}{c}0.019^{* * *} \\
(0.007)\end{array}$ & & $\begin{array}{l}-0.007 \\
(0.017)\end{array}$ \\
\hline Treatment (other exogenous) & & & $\begin{array}{c}-0.017 * * * \\
(0.005)\end{array}$ & & $\begin{array}{c}0.019^{* *} \\
(0.008)\end{array}$ & & $\begin{array}{l}-0.004 \\
(0.005)\end{array}$ \\
\hline Treatment (endogenous) & $\begin{array}{c}0.033^{* *} \\
(0.013)\end{array}$ & $\begin{array}{c}-0.015^{* *} \\
(0.007)\end{array}$ & $\begin{array}{c}-0.015^{* *} \\
(0.007)\end{array}$ & $\begin{array}{l}0.018^{*} \\
(0.010)\end{array}$ & $\begin{array}{l}0.018^{*} \\
(0.010)\end{array}$ & $\begin{array}{l}-0.004 \\
(0.015)\end{array}$ & $\begin{array}{l}-0.004 \\
(0.015)\end{array}$ \\
\hline Treatment (unclassified) & $\begin{array}{c}0.022^{* *} \\
(0.011)\end{array}$ & $\begin{array}{c}-0.014 * * * \\
(0.003)\end{array}$ & $\begin{array}{c}-0.014 * * * \\
(0.003)\end{array}$ & $\begin{array}{c}0.016^{* * * *} \\
(0.005)\end{array}$ & $\begin{array}{c}0.016^{* * *} \\
(0.005)\end{array}$ & $\begin{array}{l}-0.003 \\
(0.006)\end{array}$ & $\begin{array}{l}-0.003 \\
(0.006)\end{array}$ \\
\hline Controls & Yes & Yes & Yes & Yes & Yes & Yes & Yes \\
\hline Year FE & Yes & Yes & Yes & Yes & Yes & Yes & Yes \\
\hline Firm-state FE & Yes & Yes & Yes & Yes & Yes & Yes & Yes \\
\hline R-squared & 0.88 & 0.92 & 0.92 & 0.87 & 0.87 & 0.86 & 0.86 \\
\hline Observations & $1,748,600$ & $3,144,600$ & $3,144,600$ & $3,561,900$ & $3,561,900$ & $4,697,400$ & $4,697,400$ \\
\hline
\end{tabular}




\section{Table 11. Intensive Margin: Difference-in-Differences Analysis of Large Tax Changes}

This table presents variants of the regressions in Table 9, except that the analysis is conducted at the intensive margin, i.e. at the establishment-year level. The dependent variable is the logarithm of the number of employees at the establishment. The sample period is from 1977 to 2011 . Standard errors are clustered at the state level. *,**, and $* * *$ denotes significance at the $10 \%, 5 \%$, and $1 \%$ level, respectively.

\begin{tabular}{|c|c|c|c|c|c|c|c|c|}
\hline & \multicolumn{8}{|c|}{ log(employees $)$} \\
\hline & \multicolumn{2}{|c|}{ Large cuts in $\tau_{\mathrm{c}}$} & \multicolumn{2}{|c|}{ Large increases in $\tau_{\mathrm{c}}$} & \multicolumn{2}{|c|}{ Large cuts in $\tau_{p}$} & \multicolumn{2}{|c|}{ Large increases in $\tau_{p}$} \\
\hline & (1) & (2) & (3) & (4) & (5) & (6) & (7) & (8) \\
\hline Treatment & $\begin{array}{c}0.0032 * * * \\
(0.0007)\end{array}$ & & $\begin{array}{c}-0.0034 * * * \\
(0.0006)\end{array}$ & & $\begin{array}{c}0.0009 \\
(0.0006)\end{array}$ & & $\begin{array}{c}-0.0022 * * * \\
(0.0004)\end{array}$ & \\
\hline Treatment $(-2)$ & & $\begin{array}{l}-0.0007 \\
(0.0010)\end{array}$ & & $\begin{array}{c}0.0007 \\
(0.0007)\end{array}$ & & $\begin{array}{c}0.0002 \\
(0.0007)\end{array}$ & & $\begin{array}{c}0.0003 \\
(0.0006)\end{array}$ \\
\hline Treatment $(-1)$ & & $\begin{array}{l}-0.0016 \\
(0.0011)\end{array}$ & & $\begin{array}{c}0.0011 \\
(0.0007)\end{array}$ & & $\begin{array}{l}-0.0003 \\
(0.0008)\end{array}$ & & $\begin{array}{c}0.0002 \\
(0.0006)\end{array}$ \\
\hline Treatment (0) & & $\begin{array}{c}0.0015 \\
(0.0011)\end{array}$ & & $\begin{array}{c}-0.0018^{* *} \\
(0.0008)\end{array}$ & & $\begin{array}{c}0.0007 \\
(0.0009)\end{array}$ & & $\begin{array}{l}-0.0011 \\
(0.0007)\end{array}$ \\
\hline Treatment $(+1)$ & & $\begin{array}{c}0.0027 * * \\
(0.0012)\end{array}$ & & $\begin{array}{c}-0.0045 * * * \\
(0.0009)\end{array}$ & & $\begin{array}{c}0.0008 \\
(0.0010)\end{array}$ & & $\begin{array}{c}-0.0027 * * * \\
(0.0007)\end{array}$ \\
\hline Treatment $(+2)$ & & $\begin{array}{c}0.0033^{* * *} \\
(0.0011)\end{array}$ & & $\begin{array}{c}-0.0051 * * * \\
(0.0011)\end{array}$ & & $\begin{array}{c}0.0014 \\
(0.0011)\end{array}$ & & $\begin{array}{c}-0.0031 * * * \\
(0.0008)\end{array}$ \\
\hline Controls & Yes & Yes & Yes & Yes & Yes & Yes & Yes & Yes \\
\hline Year FE & Yes & Yes & Yes & Yes & Yes & Yes & Yes & Yes \\
\hline Establishment FE & Yes & Yes & Yes & Yes & Yes & Yes & Yes & Yes \\
\hline $\begin{array}{l}\text { R-squared } \\
\text { Observations }\end{array}$ & $\begin{array}{c}0.94 \\
1,326,800\end{array}$ & $\begin{array}{c}0.94 \\
1,326,800\end{array}$ & $\begin{array}{c}0.95 \\
1,950,600\end{array}$ & $\begin{array}{c}0.95 \\
1,950,600\end{array}$ & $\begin{array}{c}0.93 \\
2,420,100\end{array}$ & $\begin{array}{c}0.93 \\
2,420,100\end{array}$ & $\begin{array}{c}0.94 \\
3,364,500\end{array}$ & $\begin{array}{c}0.94 \\
3,364,500\end{array}$ \\
\hline
\end{tabular}




\section{Table 12. Intensive Margin: Difference-in-Differences Analysis of Large Tax Changes—Textual Analysis}

This table presents regressions similar to those in Table 10, except that the analysis is conducted at the intensive margin, i.e. at the establishment-year level. The dependent variable is the logarithm of the number of employees at the establishment. The sample period is from 1977 to 2011 . Standard errors are clustered at the state level. *,**, and $* * *$ denotes significance at the $10 \%, 5 \%$, and $1 \%$ level, respectively.

$\log ($ employees $)$

\begin{tabular}{|c|c|c|c|c|c|c|}
\hline \multirow{2}{*}{$\begin{array}{c}\text { Large cuts in } \tau_{\mathrm{c}} \\
\text { (1) }\end{array}$} & \multicolumn{2}{|c|}{ Large increases in $\tau_{\mathrm{c}}$} & \multicolumn{2}{|c|}{ Large cuts in $\tau_{\mathrm{p}}$} & \multicolumn{2}{|c|}{ Large increases in $\tau_{\mathrm{p}}$} \\
\hline & (2) & (3) & (4) & (5) & (6) & (7) \\
\hline \multirow[t]{4}{*}{$\begin{array}{c}0.0030 * * * \\
(0.0009)\end{array}$} & $\begin{array}{c}-0.0036 * * * \\
(0.0006)\end{array}$ & & $\begin{array}{c}0.0009 \\
(0.0008)\end{array}$ & & $\begin{array}{c}-0.0022 * * * \\
(0.0005)\end{array}$ & \\
\hline & & $\begin{array}{c}-0.0043 * * * \\
(0.0016)\end{array}$ & & & & \\
\hline & & & & $\begin{array}{c}0.0010 \\
(0.0012)\end{array}$ & & $\begin{array}{c}-0.0018 \\
(0.0019)\end{array}$ \\
\hline & & $\begin{array}{c}-0.0035 * * * \\
(0.0007)\end{array}$ & & $\begin{array}{c}0.0009 \\
(0.0008)\end{array}$ & & $\begin{array}{c}-0.0023 * * * \\
(0.0006)\end{array}$ \\
\hline $0.0037^{*}$ & $-0.0029 * * *$ & $-0.0028 * * *$ & 0.0008 & 0.0008 & $-0.0018^{*}$ & $-0.0019^{*}$ \\
\hline$(0.0022)$ & $(0.0008)$ & $(0.0008)$ & $(0.0009)$ & $(0.0009)$ & $(0.0010)$ & $(0.0010)$ \\
\hline $0.0033^{*}$ & $-0.0031 * *$ & $-0.0032 * *$ & 0.0009 & 0.0009 & $-0.0021 * *$ & $-0.0021 * *$ \\
\hline$(0.0017)$ & $(0.0013)$ & $(0.0013)$ & $(0.0013)$ & $(0.0013)$ & $(0.0010)$ & $(0.0010)$ \\
\hline Yes & Yes & Yes & Yes & Yes & Yes & Yes \\
\hline Yes & Yes & Yes & Yes & Yes & Yes & Yes \\
\hline Yes & Yes & Yes & Yes & Yes & Yes & Yes \\
\hline 0.94 & 0.95 & 0.95 & 0.93 & 0.93 & 0.94 & 0.94 \\
\hline $1,326,800$ & $1,950,600$ & $1,950,600$ & $2,420,100$ & $2,420,100$ & $3,364,500$ & $3,364,500$ \\
\hline
\end{tabular}




\section{Table 13. Apportionment Factors and Throwback Rules}

This table presents variants of the regressions in column (2) of Table 4 (extensive margin) and column (2) of Table 7 (intensive margin), accounting for apportionment factors and throwback rules. $\alpha_{\text {Sales }}$ denotes the sales apportionment factor; $I_{\text {Throwback }}$ is an indicator variable equal to one if the state has a throwback (or throwout) rule. The sample period is from 1977 to 2011. Standard errors are clustered at the state level. *,**, and *** denotes significance at the $10 \%, 5 \%$, and $1 \%$ level, respectively.

\begin{tabular}{|c|c|c|c|c|}
\hline & \multicolumn{2}{|c|}{ Extensive margin } & \multicolumn{2}{|c|}{ Intensive margin } \\
\hline & \multicolumn{2}{|c|}{ \# Establishments \# Establishments } & \multirow{2}{*}{$\frac{\log (\text { employees })}{(3)}$} & \multirow{2}{*}{$\frac{\log (\text { employees })}{(4)}$} \\
\hline & (1) & $(2)$ & & \\
\hline \multirow[t]{2}{*}{$\tau_{\mathrm{c}} \times$ C-Corp } & $-0.013 * *$ & $-0.010 * *$ & $-0.0015^{*}$ & $-0.0013^{*}$ \\
\hline & $(0.005)$ & $(0.005)$ & $(0.0008)$ & $(0.0008)$ \\
\hline \multirow[t]{2}{*}{$\tau_{\mathrm{c}} \times$ Pass-through } & -0.000 & 0.000 & -0.0001 & -0.0000 \\
\hline & $(0.007)$ & $(0.006)$ & $(0.0014)$ & $(0.0016)$ \\
\hline \multirow[t]{2}{*}{$\tau_{\mathrm{p}} \times$ C-Corp } & 0.001 & 0.000 & -0.0002 & -0.0003 \\
\hline & $(0.004)$ & $(0.004)$ & $(0.0008)$ & $(0.0008)$ \\
\hline \multirow[t]{2}{*}{$\tau_{\mathrm{p}} \times$ Pass-through } & -0.006 & -0.005 & -0.0009 & -0.0006 \\
\hline & $(0.006)$ & $(0.006)$ & $(0.0012)$ & $(0.0013)$ \\
\hline \multirow[t]{2}{*}[\tau_{\mathrm{c}}\times(1-\alpha\text{Sales})]{$\times$ C-Corp } & $-0.041 * * *$ & & $-0.0049 * * *$ & \\
\hline & $(0.005)$ & & $(0.0008)$ & \\
\hline \multirow[t]{2}{*}[\tau_{\mathrm{c}}\times(1-\text{asales})]{$\times$ Pass -through } & -0.002 & & -0.0004 & \\
\hline & $(0.005)$ & & $(0.0015)$ & \\
\hline \multirow[t]{2}{*}[\tau_{\mathrm{p}}\times(1-\alpha\text{Sales})]{$\times$ C-Corp } & -0.001 & & -0.0002 & \\
\hline & $(0.005)$ & & $(0.0008)$ & \\
\hline \multirow{2}{*}[\tau_{\mathrm{p}}\times(1-\alpha\text{Sales})]{$\times$ Pass-through } & $-0.013 * *$ & & $-0.0021^{*}$ & \\
\hline & $(0.006)$ & & $(0.0012)$ & \\
\hline \multirow[t]{2}{*}[\tau_{\mathrm{c}}\times(1-\text{aSales}\times(1-\text{IThrowback}))]{$\times$ C-Corp } & & $-0.026 * * *$ & & $-0.0032 * * *$ \\
\hline & & $(0.004)$ & & $(0.0008)$ \\
\hline \multirow[t]{2}{*}[\tau_{\mathrm{c}}\times(1-\alpha\text{Sales}\times(1-\text{IThrowback}))]{$\times$ Pass-through } & & -0.001 & & -0.0002 \\
\hline & & $(0.006)$ & & $(0.0019)$ \\
\hline \multirow[t]{2}{*}[\tau_{\mathrm{p}}\times(1-\alpha_{\text{Sales}}\times(1-\text{IThrowback}))]{$\times$ C-Corp } & & -0.003 & & -0.0003 \\
\hline & & $(0.005)$ & & $(0.0008)$ \\
\hline \multirow[t]{2}{*}[\tau_{\mathrm{p}}\times(1-\alpha\text{Sales}\times(1-\text{IThrowback}))]{$\times$ Pas s-through } & & $-0.011 * *$ & & $-0.0017^{*}$ \\
\hline & & $(0.005)$ & & $(0.0010)$ \\
\hline Controls & Yes & Yes & Yes & Yes \\
\hline Year FE & Yes & Yes & Yes & Yes \\
\hline Firm-state FE & Yes & Yes & No & No \\
\hline Establishment FE & No & No & Yes & Yes \\
\hline R-squared & 0.73 & 0.73 & 0.88 & 0.88 \\
\hline Observations & $32,997,200$ & $32,997,200$ & $27,600,100$ & $27,600,100$ \\
\hline
\end{tabular}




\section{Table 14. Apportionment Factors and Throwback Rules-Manufacturing}

This table presents variants of the regression in column (2) of Table 7. The sample is restricted to establishments in the ASM/CMF. $\log$ (capital) is the logarithm of the establishment's capital stock. Capital stock is constructed using the perpetual inventory method. $\tau_{c}$ (AF-adjusted) is the apportionment factor-adjusted corporate income tax rate. $\tau_{c}$ $\left(A F-\& T B\right.$-adjusted) is the apportionment factor and throwback rule-adjusted corporate income tax rate. $\tau_{p}(A F-$ adjusted) and $\tau_{p}$ (AF \& TB-adjusted) are defined analogously. The sample period is from 1977 to 2011. Standard errors are clustered at the state level. *, ${ }^{* *}$, and ${ }^{* * *}$ denotes significance at the $10 \%, 5 \%$, and $1 \%$ level, respectively.

\begin{tabular}{|c|c|c|c|c|c|c|}
\hline & $\begin{array}{c}\log (\text { emp. }) \\
(1)\end{array}$ & $\begin{array}{c}\log (\text { capital }) \\
\text { (2) }\end{array}$ & $\begin{array}{c}\log (\mathrm{emp} .) \\
\text { (3) }\end{array}$ & $\begin{array}{c}\log (\text { capital }) \\
\text { (4) }\end{array}$ & $\begin{array}{c}\log (\mathrm{emp} .) \\
(5)\end{array}$ & $\begin{array}{c}\log (\text { capital) } \\
\text { (6) }\end{array}$ \\
\hline$\tau_{\mathrm{c}} \times$ C-Corp & $\begin{array}{c}-0.0033 * * * \\
(0.0011)\end{array}$ & $\begin{array}{c}-0.0021 * * * \\
(0.0008)\end{array}$ & & & & \\
\hline$\tau_{\mathrm{c}} \times$ Pass-through & $\begin{array}{l}-0.0003 \\
(0.0023)\end{array}$ & $\begin{array}{c}0.0001 \\
(0.0015)\end{array}$ & & & & \\
\hline$\tau_{\mathrm{p}} \times$ C-Corp & $\begin{array}{l}-0.0009 \\
(0.0008)\end{array}$ & $\begin{array}{l}-0.0002 \\
(0.0005)\end{array}$ & & & & \\
\hline$\tau_{\mathrm{p}} \times$ Pass-through & $\begin{array}{l}-0.0025 \\
(0.0022)\end{array}$ & $\begin{array}{l}-0.0013 \\
(0.0015)\end{array}$ & & & & \\
\hline$\tau_{c}(A F-a d j$.$) \times C-Corp$ & & & $\begin{array}{c}-0.0042 * * * \\
(0.0012)\end{array}$ & $\begin{array}{c}-0.0027 * * * \\
(0.0008)\end{array}$ & & \\
\hline$\tau_{c}($ AF-adj. $) \times$ Pass-through & & & $\begin{array}{l}-0.0013 \\
(0.0023)\end{array}$ & $\begin{array}{l}-0.0005 \\
(0.0015)\end{array}$ & & \\
\hline$\tau_{\mathrm{p}}($ AF-adj. $) \times$ C-Corp & & & $\begin{array}{l}-0.0010 \\
(0.0008)\end{array}$ & $\begin{array}{l}-0.0003 \\
(0.0005)\end{array}$ & & \\
\hline$\tau_{\mathrm{p}}($ AF-adj. $) \times$ Pass-through & & & $\begin{array}{l}-0.0027 \\
(0.0022)\end{array}$ & $\begin{array}{l}-0.0014 \\
(0.0015)\end{array}$ & & \\
\hline$\tau_{c}(A F-\&$ TB-adj. $) \times$ C-Corp & & & & & $\begin{array}{c}-0.0044 * * * \\
(0.0013)\end{array}$ & $\begin{array}{c}-0.0029 * * * \\
(0.0009)\end{array}$ \\
\hline$\tau_{\mathrm{c}}(\mathrm{AF}-\& \mathrm{~TB}-\mathrm{adj}$.$) \times Pass-through$ & & & & & $\begin{array}{l}-0.0012 \\
(0.0025)\end{array}$ & $\begin{array}{l}-0.0006 \\
(0.0017)\end{array}$ \\
\hline$\tau_{\mathrm{p}}(\mathrm{AF}-\&$ TB-adj. $) \times$ C-Corp & & & & & $\begin{array}{l}-0.0011 \\
(0.0008)\end{array}$ & $\begin{array}{l}-0.0004 \\
(0.0005)\end{array}$ \\
\hline$\tau_{\mathrm{p}}($ AF- $\&$ TB-adj. $) \times$ Pass-through & & & & & $\begin{array}{l}-0.0026 \\
(0.0023)\end{array}$ & $\begin{array}{l}-0.0014 \\
(0.0015)\end{array}$ \\
\hline Controls & Yes & Yes & Yes & Yes & Yes & Yes \\
\hline Year FE & Yes & Yes & Yes & Yes & Yes & Yes \\
\hline Establishment FE & Yes & Yes & Yes & Yes & Yes & Yes \\
\hline R-squared & 0.92 & 0.96 & 0.92 & 0.96 & 0.92 & 0.96 \\
\hline Observations & 854,700 & 854,700 & 854,700 & 854,700 & 854,700 & 854,700 \\
\hline
\end{tabular}




\section{Appendix Table A1. Extensive Margin: Conditional Logit}

This table presents variants of the baseline specification presented in column (2) of Table 4, except that the dependent variable is a dummy indicating the state with the largest increase (and decrease, respectively) in the number of establishments for a given firm in a given year. The regressions are estimated using a conditional logit. The sample period is from 1977 to 2011. Standard errors are clustered at the state level. *, **, and *** denotes significance at the $10 \%, 5 \%$, and $1 \%$ level, respectively.

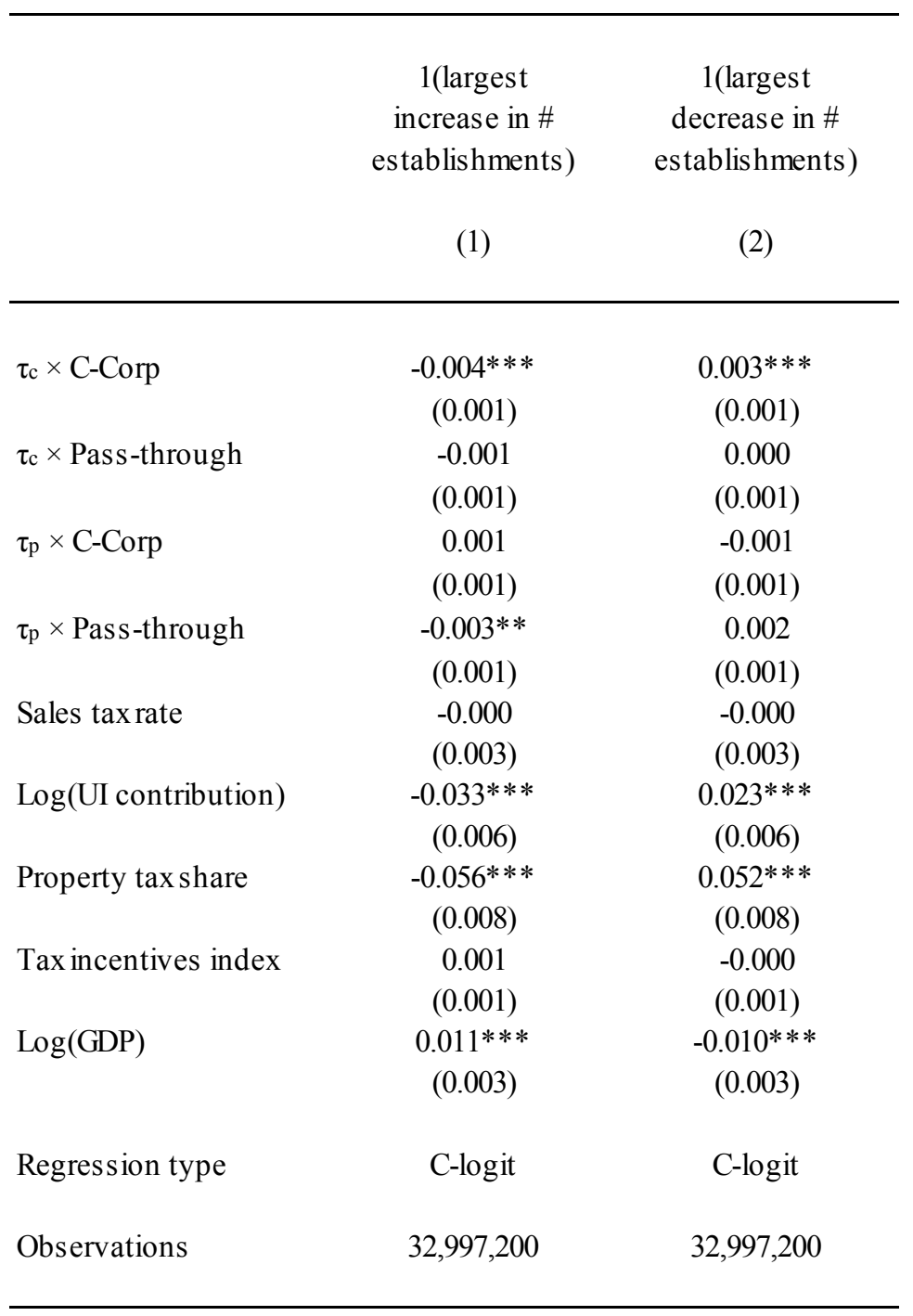




\section{Appendix Table A2. Changes in Legal Form of Organization}

The dependent variable is a dummy indicating whether the company is a C-corporation. $\bar{\tau}_{C}$ refers to the average corporate income tax rate in all states in which the company has operations. The average is computed using the share of the company's employees in each state as weights. The other tax items are computed analogously. The sample period is from 1977 to 2011 . Standard errors are clustered at the firm level. *,**, and *** denotes significance at the $10 \%, 5 \%$, and $1 \%$ level, respectively.

\begin{tabular}{|c|c|}
\hline & C-Corp \\
\hline \multirow[t]{2}{*}{$\overline{\tau_{\mathrm{c}}}$} & -0.0009 \\
\hline & $(0.0010)$ \\
\hline \multirow[t]{2}{*}{$\overline{\tau_{\mathrm{p}}}$} & 0.0006 \\
\hline & $(0.0011)$ \\
\hline \multirow[t]{2}{*}{ Sales tax rate } & 0.0011 \\
\hline & $(0.0020)$ \\
\hline \multirow[t]{2}{*}{ Log(UI contribution) } & -0.0099 \\
\hline & $(0.0085)$ \\
\hline \multirow[t]{2}{*}{ Property tax share } & -0.0114 \\
\hline & $(0.0377)$ \\
\hline \multirow[t]{2}{*}{ Tax incentives index } & $-0.0009^{*}$ \\
\hline & $(0.0005)$ \\
\hline \multirow[t]{2}{*}{$\log (G D P)$} & 0.0025 \\
\hline & $(0.0040)$ \\
\hline Year FE & Yes \\
\hline Firm FE & Yes \\
\hline R-squared & 0.79 \\
\hline Observations & 647,000 \\
\hline
\end{tabular}




\section{Appendix Table A3. Predictive Regressions for $\tau_{c}$ and $\tau_{p}$}

This table reports the regressions underlying the calculation of the "unpredicted component" of $\tau_{\mathrm{c}}$ and $\tau_{\mathrm{p}}$ used in column (5) of Tables 5 and 8. GDP is the state's gross domestic product (from the BEA). Unemployment rate is the state unemployment rate (from the BLS). Budget surplus is the state's budget balance, computed as (revenues expenditures) / expenditures, using data from the U.S. Census Bureau's State \& Local Finances database. All other variables are defined in Table 2. The sample period is from 1978 to 2011. Standard errors are clustered at the state level. *, ${ }^{* *}$, and ${ }^{* * *}$ denotes significance at the $10 \%, 5 \%$, and $1 \%$ level, respectively.

\begin{tabular}{lcc}
\hline & $\tau_{\mathrm{c}, t}$ & $\tau_{\mathrm{p}, t}$ \\
& & \\
\hline & $0.9930^{* * *}$ & \\
$\tau_{\mathrm{c}, t-1}$ & $(0.0058)$ & \\
& & $0.9636^{* * *}$ \\
$\tau_{\mathrm{p}, t-1}$ & $(0.0087)$ \\
& & 0.0172 \\
$\log (\mathrm{GDP})_{t-1}$ & $-0.0141^{*}$ & $(0.0194)$ \\
& $(0.0076)$ & -0.0004 \\
Unemployment rate $t_{t-1}$ & $0.0087^{*}$ & $(0.0115)$ \\
& $(0.0047)$ & $-0.2837^{* * *}$ \\
Budget surplus $t_{t-1}$ & -0.0785 & $(0.0939)$ \\
& $(0.0906)$ & 0.96 \\
R-squared & & 1,734 \\
Observations & 0.98 & \\
& 1,734 &
\end{tabular}




\section{Appendix Table A4. Firm-Level Regressions}

This table presents firm-level analogues of the regressions in Tables 4, 7, and 14. $\bar{\tau}_{C}$ refers to the average corporate income tax rate in all states in which the company has operations. The average is computed using the share of the company's employees in each state as weights. The other tax items are computed analogously. The sample period is from 1977 to 2011. Standard errors are clustered at the firm level. *, **, and $* * *$ denotes significance at the $10 \%$, $5 \%$, and $1 \%$ level, respectively.

\begin{tabular}{|c|c|c|c|c|c|}
\hline & \multicolumn{2}{|c|}{ LBD (all sectors) } & \multicolumn{3}{|c|}{ ASM/CMF (manufacturing) } \\
\hline & $\log$ (establishments) & $\log ($ employees $)$ & $\log ($ establishments $)$ & $\log ($ employees $)$ & $\log ($ capital $)$ \\
\hline & (1) & (2) & (3) & (4) & (5) \\
\hline$\overline{\tau_{\mathrm{c}}} \times$ C-Corp & $\begin{array}{c}-0.0015^{* * *} \\
(0.0004)\end{array}$ & $\begin{array}{c}-0.0022 * * * \\
(0.0006)\end{array}$ & $\begin{array}{l}-0.0016^{*} \\
(0.0010)\end{array}$ & $\begin{array}{c}-0.0018^{* *} \\
(0.0009)\end{array}$ & $\begin{array}{c}-0.0015^{*} \\
(0.0009)\end{array}$ \\
\hline$\overline{\tau_{\mathrm{c}}} \times$ Pass-through & $\begin{array}{c}0.0003 \\
(0.0006)\end{array}$ & $\begin{array}{c}0.0003 \\
(0.0009)\end{array}$ & $\begin{array}{c}0.0001 \\
(0.0022)\end{array}$ & $\begin{array}{c}0.0001 \\
(0.0021)\end{array}$ & $\begin{array}{c}0.0003 \\
(0.0020)\end{array}$ \\
\hline$\overline{\tau_{p}} \times$ C-Corp & $\begin{array}{c}-0.0002 \\
(0.0003)\end{array}$ & $\begin{array}{c}0.0004 \\
(0.0005)\end{array}$ & $\begin{array}{c}0.0001 \\
(0.0008)\end{array}$ & $\begin{array}{l}-0.0002 \\
(0.0008)\end{array}$ & $\begin{array}{c}0.0003 \\
(0.0008)\end{array}$ \\
\hline$\overline{\tau_{\mathrm{p}}} \times$ Pass-through & $\begin{array}{l}-0.0011^{*} \\
(0.0006)\end{array}$ & $\begin{array}{c}-0.0015^{*} \\
(0.0009)\end{array}$ & $\begin{array}{l}-0.0012 \\
(0.0024)\end{array}$ & $\begin{array}{l}-0.0013 \\
(0.0023)\end{array}$ & $\begin{array}{l}-0.0010 \\
(0.0022)\end{array}$ \\
\hline Sales tax rate & $\begin{array}{c}0.0011 \\
(0.0007)\end{array}$ & $\begin{array}{c}0.0012 \\
(0.0011)\end{array}$ & $\begin{array}{c}0.0036 \\
(0.0032)\end{array}$ & $\begin{array}{c}-0.0003 \\
(0.0031)\end{array}$ & $\begin{array}{l}-0.0028 \\
(0.0030)\end{array}$ \\
\hline Log(UI contribution) & $\begin{array}{c}-0.0082 * * * \\
(0.0019)\end{array}$ & $\begin{array}{c}-0.0064 * * \\
(0.0030)\end{array}$ & $\begin{array}{c}-0.0327 * * * \\
(0.0088)\end{array}$ & $\begin{array}{c}-0.0173 * * \\
(0.0085)\end{array}$ & $\begin{array}{c}-0.0145^{*} \\
(0.0082)\end{array}$ \\
\hline Property tax share & $\begin{array}{c}-0.0117^{*} \\
(0.0070)\end{array}$ & $\begin{array}{l}-0.0127 \\
(0.0110)\end{array}$ & $\begin{array}{c}-0.1861 * * * \\
(0.0693)\end{array}$ & $\begin{array}{c}-0.0672 \\
(0.0669)\end{array}$ & $\begin{array}{l}-0.0563 \\
(0.0642)\end{array}$ \\
\hline Tax incentives index & $\begin{array}{c}0.0011^{* * *} \\
(0.0002)\end{array}$ & $\begin{array}{c}0.0004 \\
(0.0003)\end{array}$ & $\begin{array}{c}0.0034^{* * *} * \\
(0.0007)\end{array}$ & $\begin{array}{l}0.0013^{*} \\
(0.0007)\end{array}$ & $\begin{array}{c}0.0021 * * * \\
(0.0007)\end{array}$ \\
\hline C-Corp & $\begin{array}{c}0.0610^{* * * *} \\
(0.0041)\end{array}$ & $\begin{array}{c}0.0755^{* * *} * \\
(0.0064)\end{array}$ & $\begin{array}{c}0.0790^{* * *} * \\
(0.0278)\end{array}$ & $\begin{array}{c}0.0067 \\
(0.0268)\end{array}$ & $\begin{array}{c}0.0396 \\
(0.0257)\end{array}$ \\
\hline $\log (\mathrm{GDP})$ & $\begin{array}{c}0.0047^{* * *} \\
(0.0014)\end{array}$ & $\begin{array}{c}0.0124 * * * \\
(0.0023)\end{array}$ & $\begin{array}{c}0.0048 \\
(0.0054)\end{array}$ & $\begin{array}{c}0.0217^{* * *} \\
(0.0052)\end{array}$ & $\begin{array}{l}0.0084^{*} \\
(0.0049)\end{array}$ \\
\hline Year FE & Yes & Yes & Yes & Yes & Yes \\
\hline Firm FE & Yes & Yes & Yes & Yes & Yes \\
\hline $\begin{array}{l}\text { R-squared } \\
\text { Observations }\end{array}$ & $\begin{array}{c}0.87 \\
647,000\end{array}$ & $\begin{array}{c}0.88 \\
647,000\end{array}$ & $\begin{array}{c}0.82 \\
104,400\end{array}$ & $\begin{array}{c}0.86 \\
104,400\end{array}$ & $\begin{array}{c}0.90 \\
104,400\end{array}$ \\
\hline
\end{tabular}

